\title{
REPORT OF THE RIVER MASTER OF THE DELAWARE RIVER \\ FOR THE PERIOD \\ DECEMBER 1, 2006-NOVEMBER 30, 2007
}

Open-File Report 2011-1239 


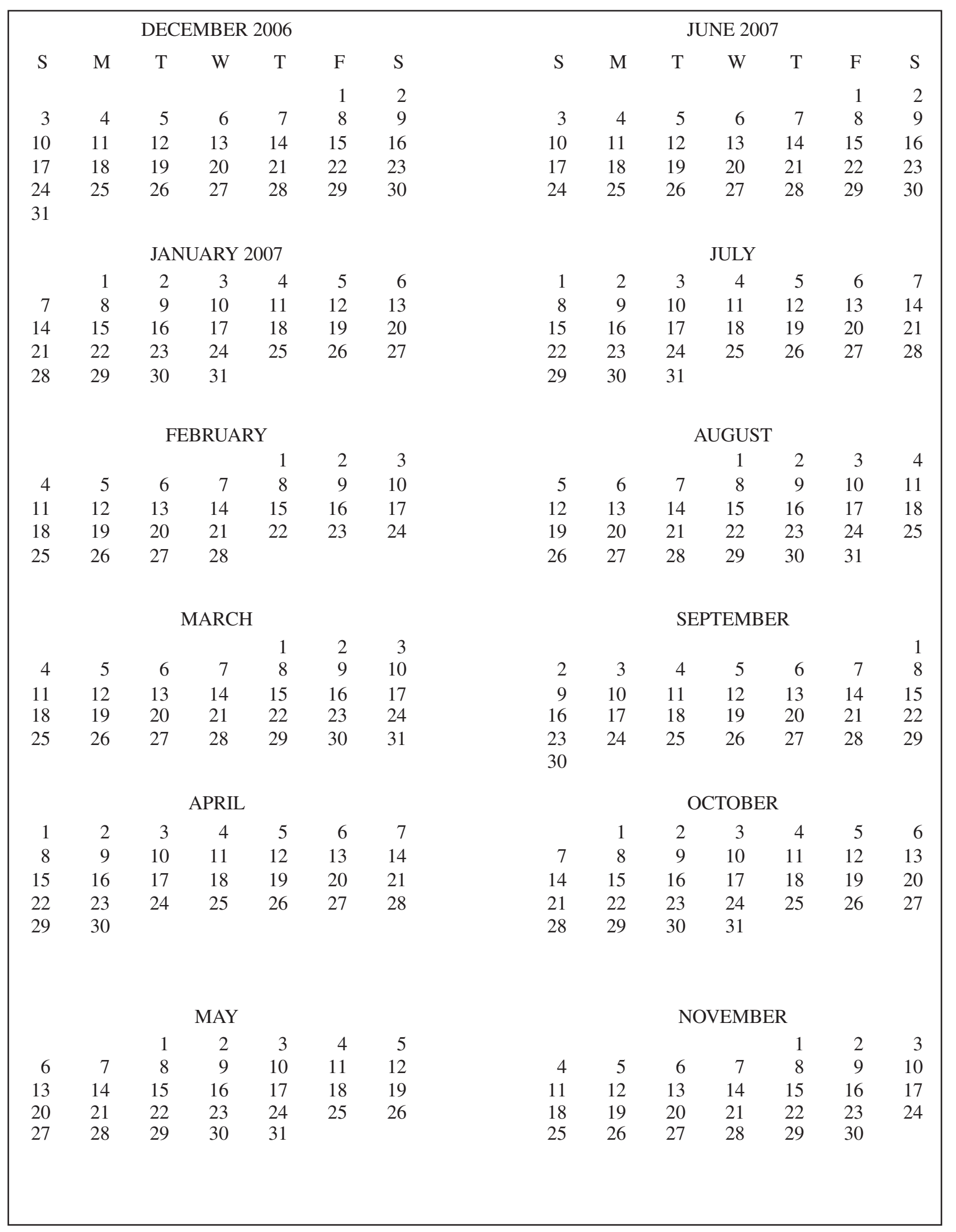




\section{Report of the River Master of the Delaware River for the period December 1, 2006-November 30, 2007}

By Bruce E. Krejmas, Gary N. Paulachok, and Stephen F. Blanchard

Open-File Report 2011-1239 


\section{U.S. Department of the Interior \\ KEN SALAZAR, Secretary \\ U.S. Geological Survey \\ Marcia K. McNutt, Director}

U.S. Geological Survey, Reston, Virginia: 2011

For more information about the USGS and its products:

Telephone: 1-888-ASK-USGS

World Wide Web: http://www.usgs.gov/

\footnotetext{
Any use of trade, product, or firm names in this publication is for descriptive purposes only and does not imply endorsement by the U.S. Government.

Although this report is in the public domain, permission must be secured from the individual copyright owners to reproduce any copyrighted materials contained within this report.

Suggested citation:

Krejmas, B.E., Paulachok, G.N., and Blanchard, S.F., 2011, Report of the River Master of the Delaware River for the period December 1, 2006-November 30, 2007; U.S. Geological Survey Open-File Report 2011-1239, 84 p.
} 


\section{Contents}

RIVER MASTER LETTER OF TRANSMITTAL AND SPECIAL REPORT ...........................................

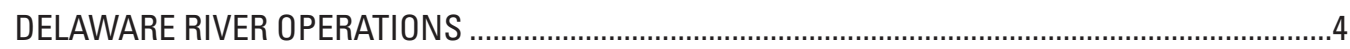

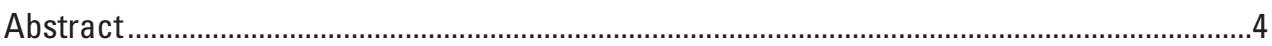

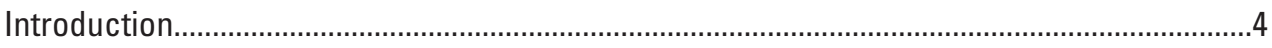

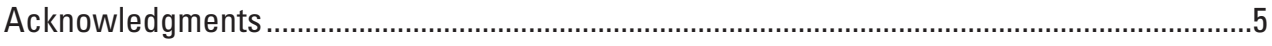

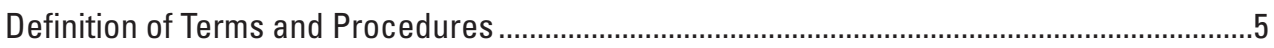

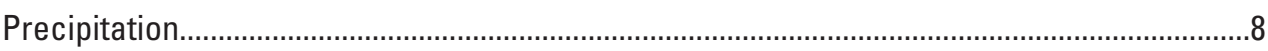

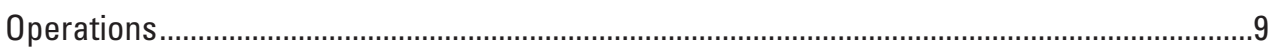

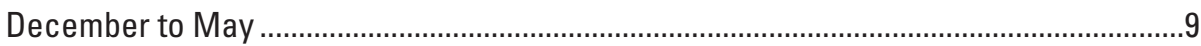

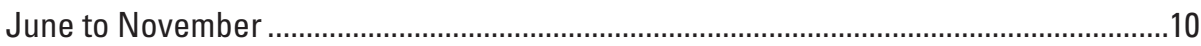

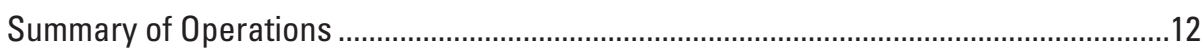

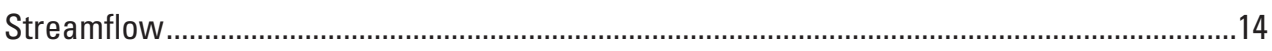

Components of Flow, Delaware River at Montague, New Jersey....................................14

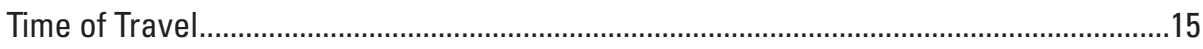

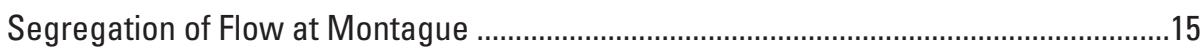

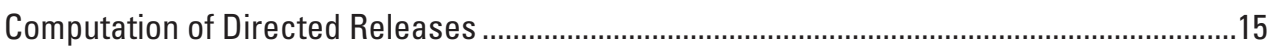

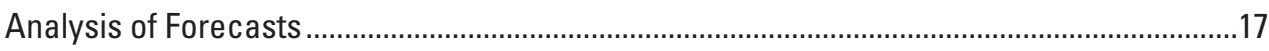

Diversions to New York City Water Supply.........................................................................

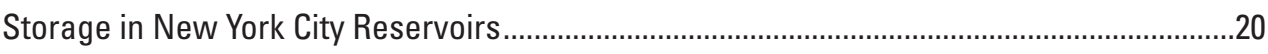

Comparison of River Master Operations Data With Other Streamflow Records....................20

Releases from New York City Reservoirs....................................................................20

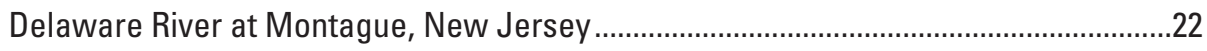

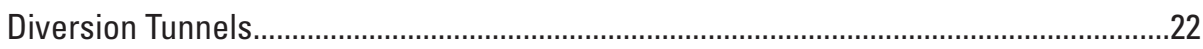

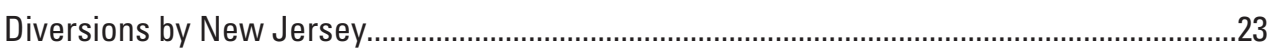

Conformance of Operations Under the Amended Decree of the U.S. Supreme Court ...........23

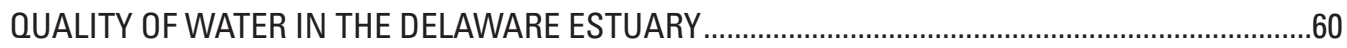

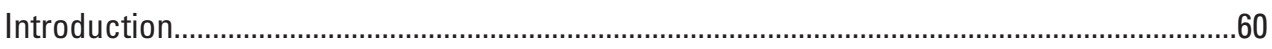

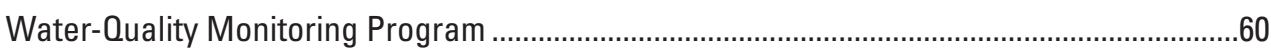

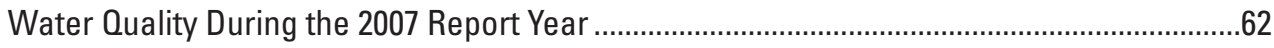

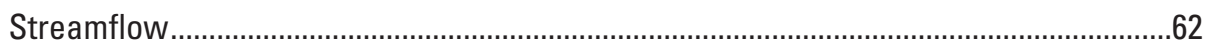

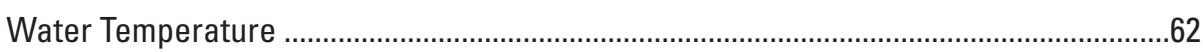

Specific Conductance and Chloride .......................................................................62

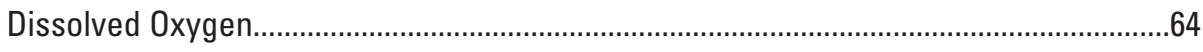

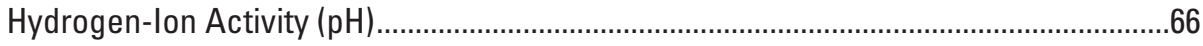

APPENDIX A. Temporary Spill Mitigation Program for Neversink, Pepacton and

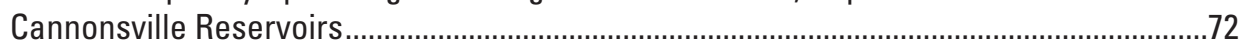

APPENDIX B. Temporary Spill Mitigation Program Summer Release Rates ..................................77

APPENDIX C. No. 2007-7, Resolution to extend Docket D-77-20 CP (Revisions 7 and 9) DRBC 


\section{Figures}

Figure 1. Map showing Delaware River Basin above Wilmington, Delaware..................................

Figure 2. Graph showing operation curves and actual contents for New York City reservoirs in the Delaware River Basin, December 1, 2006, to November 30, 2007 ..........................7

Figure 3. Components of flow, Delaware River at Montague, New Jersey, May 1 to October 31, 2007.

Figure 4. Boxplots showing combined storage in Pepacton, Cannonsville, and Neversink Reservoirs

Figure 5. Hydrograph of uncontrolled runoff component, Delaware River at Montague, New Jersey, May 1 to October 31, 2007.........................................................................18

Figure 6. Map showing location of water-quality monitoring sites on the Delaware Estuary.......61 Figures 7-9. Graphs showing:

7. Water temperature in the Delaware Estuary at Benjamin Franklin Bridge at Philadelphia, Pennsylvania, April to November.

8. Mean and minimum daily mean dissolved-oxygen concentrations from July to September at two monitor sites on the Delaware Estuary, 1965-2007.

9. Distribution of hourly dissolved-oxygen concentrations at two monitor sites on the Delaware Estuary, July to September 2007.

\section{Tables}

Table 1. Precipitation in the Delaware River Basin above Montague, New Jersey...

Table 2. Conservation release rates for New York City reservoirs in the Delaware River Basin ..24 Tables 3-5. Storage in:

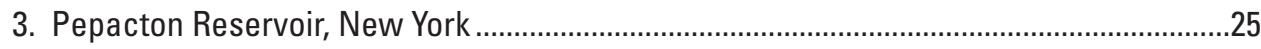

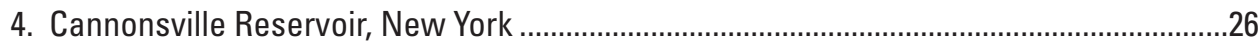

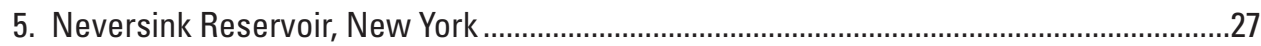

Table 6. Design rates for Delaware River at Montague, New Jersey, gaging station ....................28

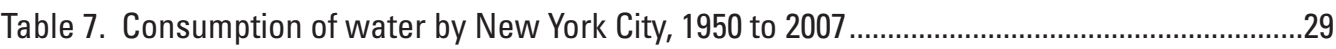

Table 8. New York City reservoir release design data ..................................................................31

Table 9. Controlled releases from reservoirs in the upper Delaware River Basin and segregation of flow of Delaware River at Montague, New Jersey..................................37

Table 10. Diversions to New York City water-supply system ............................................................49

Tables 11-14. Daily mean discharge:

11. East Branch Delaware River at Downsville, New York ……………..................................55

12. West Branch Delaware River at Stilesville, New York …………………………...............56

13. Neversink River at Neversink, New York ..........................................................................

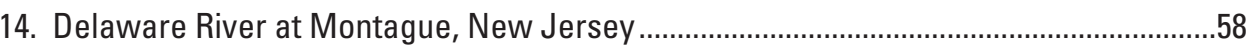

Table 15. Diversions by New Jersey; daily mean discharge, Delaware and Raritan Canal at Port Mercer, New Jersey

Table 16. Daily mean discharge, Delaware River at Trenton, New Jersey ......................................67

Tables 17-18. Daily maximum and minimum chloride concentrations:

17. Delaware River at Reedy Island Jetty, Delaware .........................................................68

18. Delaware River at Chester, Pennsylvania.......................................................................69 
Tables 19-20. Daily mean dissolved-oxygen concentration:

19. Delaware River at Benjamin Franklin Bridge at Philadelphia, Pennsylvania .. .70

20. Delaware River at Chester, Pennsylvania.....................................................................71 


\begin{tabular}{|c|c|c|}
\hline Multiply & By & To obtain \\
\hline \multicolumn{3}{|c|}{ Length } \\
\hline $\begin{array}{r}\text { inch (in.) } \\
\text { foot (ft) } \\
\text { mile (mi) }\end{array}$ & $\begin{array}{l}25.4 \\
0.3048 \\
1.609\end{array}$ & $\begin{array}{l}\text { millimeter }(\mathrm{mm}) \\
\text { meter }(\mathrm{m}) \\
\text { kilometer }(\mathrm{km})\end{array}$ \\
\hline \multicolumn{3}{|c|}{ Area } \\
\hline \multirow[t]{2}{*}{ square mile $\left(\mathrm{mi}^{2}\right)$} & 2.590 & square kilometer $\left(\mathrm{km}^{2}\right)$ \\
\hline & Volume & \multirow{6}{*}{$\begin{array}{l}\text { cubic meter }\left(\mathrm{m}^{3}\right) \\
\text { cubic foot per second day }\left(\mathrm{ft}^{3} / \mathrm{s}\right)-\mathrm{c} \\
\text { cubic hectometer }\left(\mathrm{hm}^{3}\right) \\
\text { cubic hectometer }\left(\mathrm{hm}^{3}\right)\end{array}$} \\
\hline million gallons (Mgal) & 3,785 & \\
\hline million gallons (Mgal) & 1.547 & \\
\hline billion gallons (Bgal) & 3.785 & \\
\hline cubic foot per second day $\left(\mathrm{ft}^{3} / \mathrm{s}\right)-\mathrm{d}$ & 0.002447 & \\
\hline \multicolumn{2}{|r|}{ Flow rate } & \\
\hline million gallons per day (Mgal/d) & 1.547 & cubic foot per second $\left(\mathrm{ft}^{3} / \mathrm{s}\right)$ \\
\hline million gallons per day (Mgal/d) & 0.04381 & cubic meter per second $\left(\mathrm{m}^{3} / \mathrm{s}\right)$ \\
\hline billion gallons per day (Bgal/d) & 43.81 & cubic meter per second $\left(\mathrm{m}^{3} / \mathrm{s}\right)$ \\
\hline cubic foot per second $\left(\mathrm{ft}^{3} / \mathrm{s}\right)$ & 0.02832 & cubic meter per second $\left(\mathrm{m}^{3} / \mathrm{s}\right)$ \\
\hline
\end{tabular}

Datum: Vertical coordinate information is referenced to the North American Vertical Datum of 1988. Horizontal coordinate information is referenced to the North American Datum of 1983.

Elevation, as used in this report, refers to the distance above a vertical datum.

Temperature in degrees Celsius $\left({ }^{\circ} \mathrm{C}\right)$ may be converted to degrees Fahrenheit $\left({ }^{\circ} \mathrm{F}\right)$ as follows: ${ }^{\circ} \mathrm{F}=\left(1.8 \mathrm{x}^{\circ} \mathrm{C}\right)+32$

\section{CHEMICAL CONCENTRATIONS}

In this report, concentrations of chloride and dissolved oxygen are given in milligrams per liter (mg/L). Milligrams per liter represents the mass of solute (milligrams) per unit volume (liter) of water. 


\title{
RIVER MASTER LETTER OF TRANSMITTAL AND SPECIAL REPORT
}

\author{
OFFICE OF THE DELAWARE RIVER MASTER \\ United States Geological Survey \\ 415 National Center \\ Reston, Virginia 20192
}

October 14, 2011

The Honorable

John G. Roberts, Jr.

Chief Justice of the United States

The Honorable

Jack A. Markell

Governor of Delaware

The Honorable

Christopher J. Christie

Governor of New Jersey

The Honorable

Andrew M. Cuomo

Governor of New York

The Honorable

Tom Corbett

Governor of Pennsylvania

The Honorable

Michael R. Bloomberg

Mayor of the City of New York

No. 5, Original.-October Term, 1950

State of New Jersey, Complainant, $v$.

State of New York and City of New York, Defendants, Commonwealth of Pennsylvania and State of Delaware, Intervenors.

\section{Dear Sirs:}

For the record and in compliance with the provisions of the Amended Decree of the Supreme Court of the United States entered June 7, 1954, I am hereby transmitting the 54th Annual Report of the River Master of the Delaware River for the 12-month period from December 1, 2006, to November 30, 2007. In this report, this period is referred to as the River Master report year or the report year.

During the 2007 River Master report year, monthly precipitation in the upper Delaware River Basin ranged from 40 percent of the long-term average in May 2007 to 192 percent of the long-term average in October 2007. Total precipitation during the report year was 2.90 inches (in.) more than the long-term average. Precipitation during the December to May period, when reservoirs typically refill, was 0.24 in. 
less than the 66-year average. Precipitation during the report year was below normal in December, May, June, August, and September and above normal in the other months.

On December 1, 2006, when the report year began, combined storage in the New York City reservoirs in the upper Delaware River Basin was 270.220 billion gallons (Bgal) or 99.8 percent of combined storage capacity. Median combined storage on December 1, computed on the basis of 39 years of record, is 177.521 Bgal. Storage remained high throughout the winter, and declined seasonally during the summer. During the report year, operations in the basin were conducted as stipulated by the Decree.

On May 30, 2007, the Delaware River Master Advisory Committee met at the U.S. Forest Service's Grey Towers Conference Center in Milford, Pennsylvania, to discuss hydrologic conditions in the basin and operational procedures for the 2007 reservoir-releases season. During the report year, the following individuals served as members of the Advisory Committee:

$\begin{array}{ll}\text { Delaware } & \text { John H. Talley } \\ \text { New Jersey } & \text { Mark N. Mauriello } \\ \text { New York } & \text { Mark Klotz } \\ \text { New York City } & \text { Paul Rush } \\ \text { Pennsylvania } & \text { Cathleen Curran Myers }\end{array}$

The River Master informed the Advisory Committee that, on the basis of information provided by New York City, the excess-release quantity beginning June 15, 2007, was 7.381 Bgal. Based on reservoir release programs in Delaware River Basin Commission (DRBC) Docket No. D-77-20 CP (Revisions Nos. 7,8 , and 9), the excess release quantity was to be used for various purposes, and temporary spill reduction programs already in effect were extended.

During the report year, the River Master and staff participated in a number of water-supply related meetings of the DRBC. The Deputy Delaware River Master met periodically with representatives of the Decree Parties as a member of the Decree Parties Work Group and DRBC's Regulated Flow Advisory Committee. Issues of particular interest to the River Master involved management of reservoir releases and streamflow in the upper Delaware River Basin.

On September 27, 2007, the Decree Parties approved the implementation of a Flexible Flow Management Program (FFMP), whereby diversions and releases were managed under the Decree. The FFMP became effective on October 1, 2007.

The U.S. Geological Survey (USGS) continued operation of its field office of the Delaware River Master at Milford, Pennsylvania. Gary N. Paulachok, Deputy Delaware River Master, continued in charge of the office, assisted by Bruce E. Krejmas, Hydrologist.

During the year, the River Master's office continued the weekly distribution of a summary hydrologic report. These reports contain provisional data on precipitation in the upper Delaware River Basin, releases and spills from New York City reservoirs to the Delaware River, diversions to the New York City watersupply system, reservoir contents, daily segregation of flow of the Delaware River at the USGS Montague, New Jersey gaging station, and diversions by New Jersey. The reports were distributed to members of the Delaware River Master Advisory Committee and to other parties interested in Delaware River operations. 
A monthly summary of hydrologic conditions also was provided to Advisory Committee members. The weekly and monthly hydrologic reports also were posted on the River Master's Web site.

The first section of this report documents Delaware River operations during the report year. During the year, the City of New York diverted 209.424 Bgal from the Delaware River Basin and released 221.811 Bgal from Pepacton, Cannonsville, and Neversink Reservoirs to the Delaware River. The River Master directed releases from these reservoirs to the Delaware River that totaled 55.099 Bgal.

The second section of this report describes water quality at various monitor sites on the Delaware Estuary. It includes basic data on chemical properties and physical characteristics of the water, and presents summary statistics on the data.

Throughout the year, diversions to New York City's water supply and releases designed to maintain the flow of the Delaware River at Montague were made as directed by the River Master. Diversions by New York City from its reservoirs in the Delaware River Basin did not exceed the limit stipulated by the Decree. Diversions by New Jersey also were within stipulated limits.

The River Master and staff are grateful for the continued cooperation and support of the Decree Parties. Also, the contributions of the PPL Corporation, Mirant Corporation, and Alliance Energy in informing the River Master of plans for power generation and furnishing data on reservoir releases are greatly appreciated.

Sincerely yours,

/Signed/

Stephen F. Blanchard

Delaware River Master 


\section{DELAWARE RIVER OPERATIONS}

\section{Abstract}

A Decree of the Supreme Court of the United States, entered June 7, 1954, established the position of Delaware River Master within the U.S. Geological Survey (USGS). In addition, the Decree authorizes diversions of water from the Delaware River Basin and requires compensating releases from certain reservoirs, owned by New York City, to be made under the supervision and direction of the River Master. The Decree stipulates that the River Master will furnish reports to the Court, not less frequently than annually. This report is the 54th Annual Report of the River Master of the Delaware River. It covers the 2007 River Master report year-the period from December 1, 2006, to November 30, 2007.

During the report year, precipitation in the upper Delaware River Basin was 46.72 inches (in.) or 107 percent of the long-term average. Combined storage in Pepacton, Cannonsville, and Neversink Reservoirs was high on December 1, 2006. Reservoir storage remained high throughout the winter, declined seasonally during the summer, and began to recover in mid-October. Delaware River operations throughout the year were conducted as stipulated by the Decree.

Diversions from the Delaware River Basin by New York City and New Jersey were in full compliance with the Decree. Reservoir releases were made as directed by the River Master at rates designed to meet the flow objective for the Delaware River at Montague, New Jersey, on 123 days during the report year. Releases were made at conservation rates - or rates designed to relieve thermal stress and protect the fishery and aquatic habitat in the tailwaters of the reservoirs — on all other days.

During the report year, New York City and New Jersey complied fully with the terms of the Decree, and directives and requests of the River Master.

As part of a long-term program, the quality of water in the Delaware Estuary between Trenton, New Jersey, and Reedy Island Jetty, Delaware, was monitored at various locations. Data on water temperature, specific conductance, dissolved oxygen, and $\mathrm{pH}$ were collected continuously by electronic instruments at four sites. In addition, selected water-quality data were collected at 19 sites on a twice-monthly basis and at 3 sites on a monthly basis.

\section{Introduction}

An Amended Decree of the Supreme Court of the United States, entered June 7, 1954, authorized diversions of water from the Delaware River Basin and provided for releases of water from three New York City reservoirs-Pepacton, Cannonsville, and Neversink - to the upper Delaware River. The Decree stipulated that these diversions and releases are to be made under the supervision and direction of the Delaware River Master. The Decree also stipulated that reports on Delaware River operations be made to the Court not less frequently than annually. This report documents operations from December 1, 2006, to November 30, 2007, or the 2007 River Master report year. The report also presents information on the quality of water in the Delaware Estuary during the report year.

Some hydrologic data presented in this report are records of streamflow and water quality for USGS data-collection stations. These records were collected, computed, and furnished by the offices of the 
USGS at Troy, New York; Exton and New Cumberland, Pennsylvania; and West Trenton, New Jersey, in cooperation with the States of New York and New Jersey, the Commonwealth of Pennsylvania, and the City of New York. The locations of major streams and reservoirs, and selected streamflow-gaging stations in the Delaware River Basin are shown in figure 1.

\section{Acknowledgments}

The River Master's daily operation records were prepared from hydrologic data collected chiefly on a day-to-day basis. Data for these records were collected and computed by the Office of the Delaware River Master or were furnished by the following agencies and utilities: Data for Pepacton, Cannonsville, and Neversink Reservoirs by the New York City Department of Environmental Protection, Bureau of Water Supply; for Lake Wallenpaupack by the PPL Corporation; and for Rio Reservoir by the Mirant Corporation and Alliance Energy. Precipitation data and quantitative precipitation forecasts were provided by the National Weather Service (NWS) office in Binghamton, New York.

\section{Definition of Terms and Procedures}

The following definitions apply to various terms and procedures used in the operations documented in this report. A table for converting inch-pound units to the International System of Units (SI) is given on page vi.

- Balancing Adjustment.-An operating procedure used by the River Master to correct for inaccuracies inherent in the design of releases from New York City reservoirs to meet the Montague flow objective. The balancing adjustment is computed as 10 percent of the difference between the cumulative adjusted directed release and the cumulative directed release required for exact forecasting. The balancing adjustment is applied to the following day's release design. The maximum daily balancing adjustment is intentionally limited to preclude unacceptably large variations in the adjusted flow objective.

- Capacity.-Total usable volume in a reservoir between the point of maximum depletion and the elevation of the lowest crest of the spillway.

- Conservation releases.-Controlled releases from Pepacton, Cannonsville, and Neversink Reservoirs designed to maintain specified minimum flows in stream channels immediately below the reservoirs (tailwaters). The conservation rates shown in table $2^{1}$ are defined as follows:

Normal.-Conservation releases when New York City combined reservoir storage is in the normal operations zone.

Watch.-Conservation releases when New York City combined reservoir storage is in the drought watch operations zone.

Warning.-Conservation releases when New York City combined reservoir storage is in the drought warning operations zone.

Drought.-Conservation releases the when New York City combined reservoir storage is in the drought operations zone.

The combined reservoir storage zones for the New York City Delaware Basin Reservoirs are shown in figure 2.

${ }^{1}$ All numbered tables in the section "Delaware River Operations" are grouped at the end of this section, beginning on page 24. 


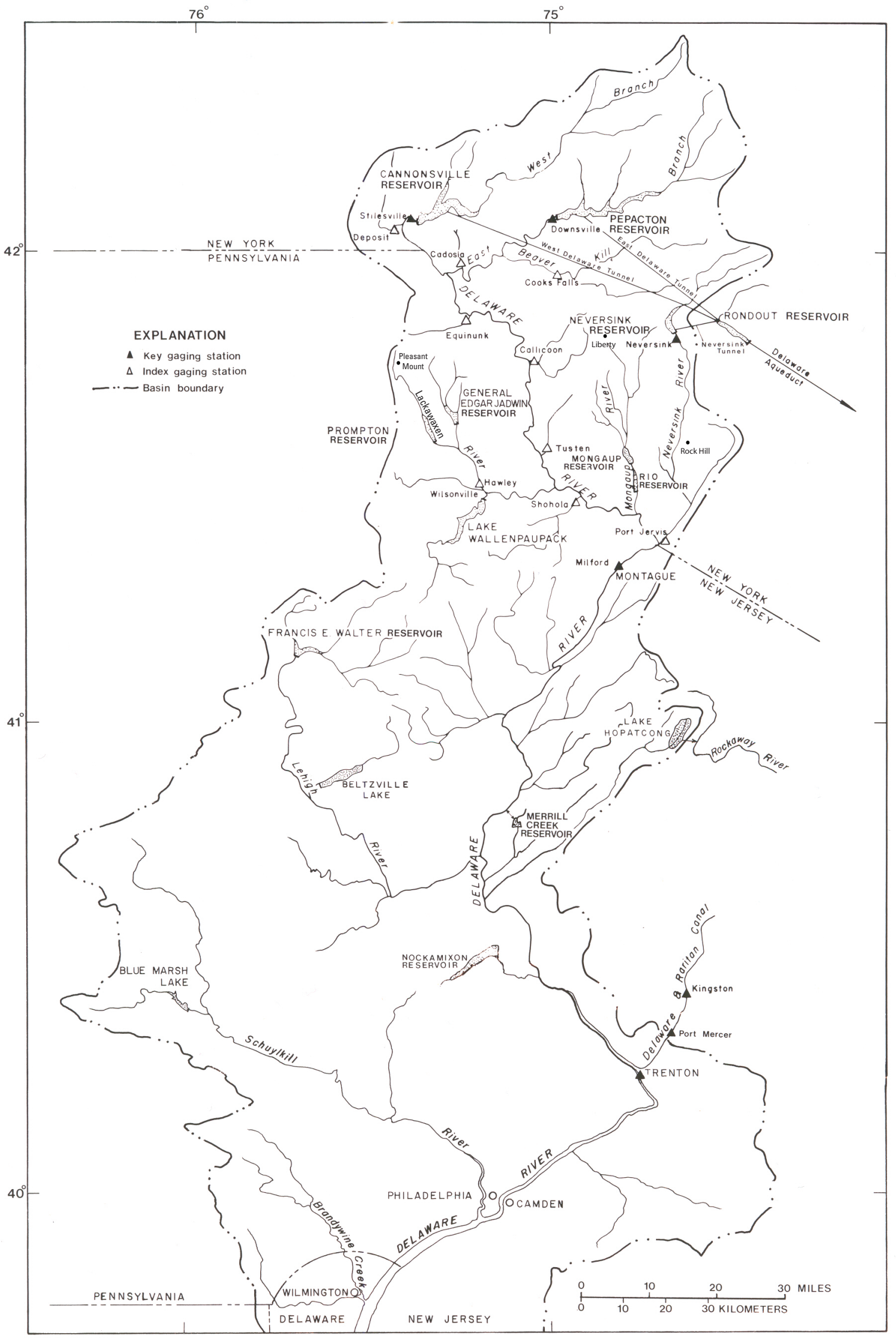

Figure 1. Delaware River Basin above Wilmington, Delaware. 


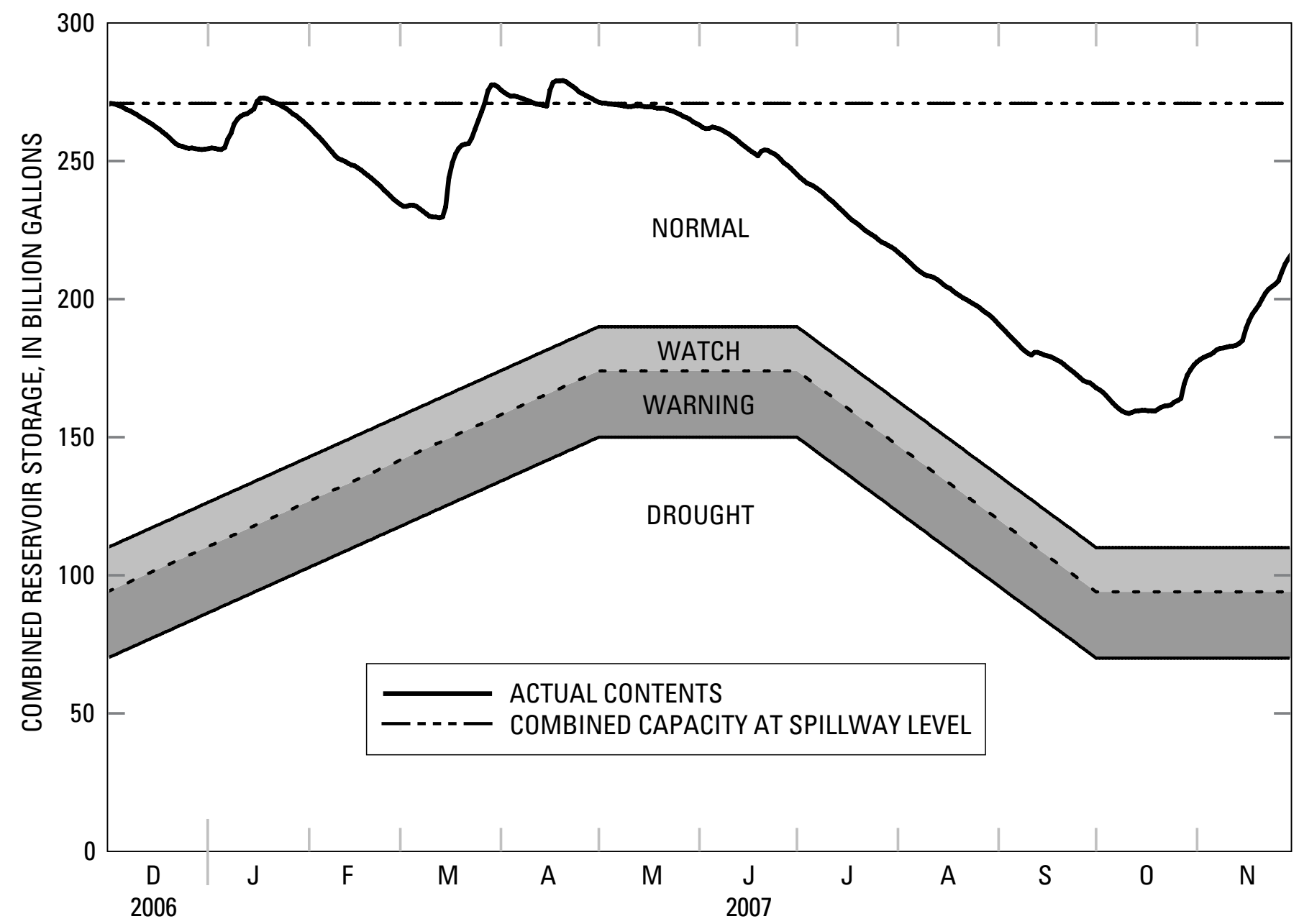

Figure 2. Operation curves and actual contents for New York City reservoirs in the Delaware River Basin, December 1, 2006, to November 30, 2007.

- Daily excess-release credits.-Daily credits and deficits during the seasonal release period (June 15 to the following March 15) are computed as the arithmetic difference between the daily mean discharge of the Delaware River at Montague, New Jersey, and 1,750 cubic feet per second $\left(\mathrm{ft}^{3} / \mathrm{s}\right)$. The daily credit cannot exceed the 24-hour period releases from Pepacton, Cannonsville, and Neversink Reservoirs routed to Montague and made in accordance with direction, except as follows: during the seasonal period, credits also are applied for part or all of other releases from these reservoirs that contribute to the daily mean discharge at Montague between 1,750 ft3 $3 / \mathrm{s}$ and the applicable excessrelease rate.

- Directed releases. - Controlled releases from New York City reservoirs in the upper Delaware River Basin, designed by the Delaware River Master to meet the Montague flow objective.

- Diversions.-The out-of-basin transfer of water by New York City from Pepacton, Cannonsville, and Neversink Reservoirs in the upper Delaware River Basin through the East Delaware, West Delaware, and Neversink Tunnels, respectively, to the City's water-supply system. Also, the out-of-basin transfer of water by New Jersey from the Delaware River through the Delaware and Raritan Canal.

- Excess quantity.-As defined by the Decree, the excess quantity of water is equal to 83 percent of the amount by which the estimated consumption by New York City during the year is less than 
the City's estimate of continuous safe yield [1,665 million gallons per day (Mgal/d) stipulated by the 1954 Decree] from all its sources of supply obtainable without pumping, except that the excess quantity shall not exceed 70 Bgal. Each year, the seasonal period for release of the excess quantity begins on June 15. The flow objective for the period becomes effective at Montague on that date and remains in effect until the following March 15, or until the cumulative total of excess-release credits equals the applicable excess quantity, whichever occurs first.

- Index gaging stations.-Particular sites on tributaries of the upper Delaware River where systematic observations of gage height and discharge are made. These stations are used mainly during the directed-releases season to estimate inflows of surface water to the upper Delaware River.

- Key gaging stations.-Particular sites on the East Branch Delaware River, West Branch Delaware River, Neversink River, Delaware and Raritan Canal, and mainstem Delaware River where continuous, systematic observations of gage height and discharge are made. These stations are used on a year-round basis in River Master operations.

- Maximum reservoir depletion.-The minimum water-surface level or elevation below which a reservoir ceases to continue making delivery of quantities of water for all purposes for which the reservoir was designed. This also is referred to as minimum full-operating level.

- Rate of flow.-Mean discharge for a specified 24-hour period, in cubic feet per second or million gallons per day.

- Rate of flow at Montague.-Daily mean discharge of the Delaware River at Montague, New Jersey, computed on a calendar-day basis.

- Reservoir-controlled releases.-Controlled releases from reservoirs passed through outlet valves in the dams or through turbines in powerplants. These releases do not include spillway overflow at the reservoirs.

- Storage or contents. - Usable volume of water in a reservoir. Unless otherwise indicated, volume is computed on the basis of level pool and above the point of maximum depletion.

- Time of day.- Time of day is expressed in 24-hour Eastern Standard Time, which during the report year included a 23-hour day on March 11 and a 25-hour day on November 4.

- Uncontrolled runoff at Montague.-Runoff from the 3,480 square mile $\left(\mathrm{mi}^{2}\right)$ drainage area above Montague, New Jersey, excluding the drainage area above Pepacton, Cannonsville, Neversink, Wallenpaupack, and Rio Dams, but including spillway overflow at these dams.

\section{Precipitation}

Precipitation in the Delaware River Basin above Montague, New Jersey, totaled 46.72 in. during the 2007 report year and was 2.90 in. greater than, or 107 percent of, the long-term (66-year) average. Monthly precipitation ranged from 40 percent of the long-term average in May 2007 to 192 percent of average in October 2007. Data on monthly precipitation during the report year and long-term average precipitation are presented in table $1^{2}$. These data were computed from records collected at 10 geographically distributed stations by the NWS; the New York City Department of Environmental Protection, Bureau of Water Supply; and the River Master office.

${ }^{2}$ All numbered tables in the section "Delaware River Operation" are grouped at the end of this section, beginning on page 24. 
The seasonal period from December to May typically is when surface-water and groundwater reservoirs refill. During this period in 2006-2007, total precipitation was 20.07 in., which is 99 percent of the 66-year average. From June to November, total precipitation was 26.65 in., which is 113 percent of the long-term average. The maximum monthly precipitation was $9.27 \mathrm{in}$. in October 2007, measured at Pleasant Mount, Pennsylvania; the minimum monthly precipitation was 0.60 in. in May 2007, measured at Milford, Pennsylvania (locations shown on fig. 1).

\section{Operations}

\section{December to May}

Operations on December 1, 2006, were conducted as prescribed by the Decree. The Montague flow objective was $1,750 \mathrm{ft}^{3} / \mathrm{s}$, and the allowable diversions to New York City and New Jersey were $800 \mathrm{Mgal} / \mathrm{d}$ and $100 \mathrm{Mgal} / \mathrm{d}$, respectively. Conservation releases from New York City reservoirs were made at the rates shown in table 2, as incorporated in Delaware River Basin Commission (DRBC) docket D-77-20 CP (Revision 7).

From December 2006 to May 2007, the first half of the report year, total precipitation was 0.24 in. below average. Monthly precipitation ranged from 40 percent of the long-term average in May 2007 to 148 percent in April 2007 (table 1). Runoff in the upper basin was above normal in January, March, and April, normal in December, and below normal in February and May.

On December 1, 2006, when the 2007 report year began, Pepacton Reservoir contained 140.708 Bgal of water in storage above the point of maximum depletion, or 100.4 percent of the 140.190 Bgal storage capacity. Cannonsville Reservoir contained 96.253 Bgal, or 100.6 percent of the 95.706 Bgal storage capacity. Neversink Reservoir contained 33.259 Bgal, or 95.2 percent of the 34.941 Bgal storage capacity. Combined storage in these reservoirs on December 1, 2006, was 270.220 Bgal, or 99.8 percent of combined capacity. Daily storage in Pepacton, Cannonsville, and Neversink Reservoirs is given in tables 3, 4, and 5, respectively, and combined storage during the report year is shown in figure 2 .

On January 9, 2007, in an effort to reduce spill volumes from the New York City reservoirs during flood events, the Decree Parties implemented a temporary spill reduction program. The agreement for a temporary spill reduction program for Pepacton, Cannonsville, and Neversink Reservoirs is presented in Appendix A. On May 25, 2007, the program was extended to September 26, 2007; this agreement is shown in Appendix B. On September 21, 2007, the Decree Parties agreed to an extension of the temporary spill mitigation program to September 30, 2007.

The Decree Parties continued a conservation releases program for the New York City Delaware Basin Reservoirs that began on May 1, 2004. This program established a habitat protection bank, which consisted of an excess release quantity bank, a thermal bank, and a supplemental release bank. It also established flow targets for all three tailwaters at certain USGS gaging stations downstream of the reservoirs. On May 10, 2007, the Decree Parties agreed to extend the program, DRBC Docket No. D-77-20 CP (Revisions 7 and 9), through September 30, 2007. The extended agreement, DRBC Resolution No. 2007-7, is presented in Appendix C. 
From December to May, inflow to the City's reservoirs typically exceeds outflow and, consequently, storage increases. The average inflow to Pepacton, Cannonsville, and Neversink Reservoirs for this 6-month period, computed on the basis of the 66-year period from December 1940 to May 2006 was $302.1 \mathrm{Bgal}$. During the corresponding 6 months of the report year, inflow to the three reservoirs totaled 327.5 Bgal. Evaporation loss is not included in the computations.

Combined storage remained high and fluctuated moderately in December 2006 and January 2007. Combined storage decreased slowly from February to mid-March, then increased to full capacity in late March, and remained near full capacity until the end of May. The combined storage of the reservoirs was about 97 percent of capacity on May 31, 2007.

Combined storage in the three New York City reservoirs was 270.643 Bgal on November 30, 2006, and 263.640 Bgal on May 31, 2007, a net decrease of 7.003 Bgal or 2.6 percent of total capacity. Maximum combined storage from December to May was 279.150 Bgal on April 20, 2007. Maximum storage in Pepacton Reservoir during the December to May period was 143.406 Bgal on April 17; maximum storage in Cannonsville Reservoir was 101.484 Bgal on March 28; and maximum storage in Neversink Reser-

voir was 35.983 Bgal on April 16, 2007. Pepacton Reservoir spilled from December 1-7, January 16-23, March 27 to April 8, and April 15 to May 7. Cannonsville Reservoir spilled from December 1-8, January 13-26, March 23 to May 4, and May 11-18. Neversink Reservoir spilled from March 31 to April 27. The combined spill volume from the three reservoirs during this period was $102.145 \mathrm{Bgal}$.

During the December to May period, diversions to Rondout Reservoir by New York City totaled $89.972 \mathrm{Bgal}(494 \mathrm{Mgal} / \mathrm{d})$. The forecasted discharge at Montague, exclusive of water released from the City reservoirs, was less than the flow objective on 5 days in May, and releases were directed. The observed daily mean discharge at Montague was greater than the applicable flow objective on all days. Applicable design rates for the USGS gaging station Delaware River at Montague, New Jersey, are presented in table 6 .

\section{June to November}

Monthly precipitation for the June to November period was above average in July, October, and November, and below average in June, August, and September. Total precipitation during the period was 26.65 in. or 3.14 in. more than the 66-year average (table 1).

Combined storage in the three New York City reservoirs was 262.969 Bgal on June 1, 2007, and 216.317 Bgal on November 30, 2007, a net decrease of 46.652 Bgal or about 17 percent of total capacity. During the June to November period, maximum storage in Pepacton Reservoir was 136.927 Bgal on June 25; 93.120 Bgal in Cannonsville Reservoir on June 1; and 33.067 Bgal in Neversink Reservoir on June 6 and 7. Maximum combined storage in the three reservoirs was 262.969 Bgal on June 1, 2007. There was no spill during this period.

Releases were directed to meet the Montague flow objective on 118 days between June 1 and November 30, 2007, when the forecasted discharge at Montague, exclusive of water released from the New York City reservoirs, was less than the flow objective. Releases at rates designed to protect the fishery and aquatic habitat were made at other times during the period. 
From June 1 to June 14, the Montague flow objective was $1,750 \mathrm{ft}^{3} / \mathrm{s}$. The forecasted flow, exclusive of releases from Pepacton, Cannonsville, and Neversink Reservoirs, was less than the flow objective on 10 days and releases were directed.

The New York City Department of Environmental Protection, Bureau of Water Supply, Quality, and Protection furnished the River Master with the following data for the 2007 calendar year, as stipulated by the Decree:

1. The estimated continuous safe yield from all the City's sources, obtainable without pumping, is $1,665 \mathrm{Mgal} / \mathrm{d}$, or a total during calendar year 2007 of $1.665 \mathrm{Bgal} / \mathrm{d}$ x 365 days $=607.725 \mathrm{Bgal}$.

2. The estimated consumption that the City must provide for, from all its sources of supply during calendar year 2007, is $591.582+7.250=598.832$ Bgal.

On the basis of the Decree and the above-noted data, the aggregate quantity of excess-release water was 83 percent of (607.725 - 598.832), or 7.381 Bgal.

Data on water consumption by the City of New York for each calendar year since 1950, from all sources of supply, are presented in table 7.

As part of the reservoir releases program stipulated in DRBC Docket No. D-77-20 CP (Revision No. 7), about 50 percent of the annual excess release quantity was placed in a habitat protection bank. The remainder of the excess release quantity could be used to provide an increase in the Montague flow objective or could be banked in accordance with the procedures given in the DRBC's Lower Basin Drought Management Plan.

On June 15, 2007, the beginning of the seasonal excess release period, the Montague flow objective was increased to $1,800 \mathrm{ft}^{3} / \mathrm{s}$. Storage in the New York City reservoirs declined slowly from June to midOctober, after which storage increased steadily through the end of the report year.

On September 27, 2007, a Flexible Flow Management Program (FFMP) was approved, whereby the Decree Parties agreed to manage diversions and releases under the Decree. The FFMP went into effect on October 1, 2007. The FFMP is designed to provide safe and reliable supplies of water essential to serve the needs of more than 17 million people who depend on water from New York City's Cannonsville, Pepacton, and Neversink Reservoirs (City Delaware Basin Reservoirs) and their tailwaters, and the Delaware River; to manage discharges from the City Delaware Basin Reservoirs; to provide flows to help control temperatures in the tailwaters in support of the cold water fishery; to assist in mitigating the impacts of flooding; and to provide flows in the main stem and the Delaware Bay to help protect ecological health, support withdrawal and non-withdrawal uses, and repel salinity. The FFMP agreement can be accessed at the following url: http://water.usgs.gov/osw/odrm/.

The FFMP established an Interim Excess Release Quantity, which could be used to help maintain a daily mean flow at Trenton of 3,000 ft $3 / \mathrm{s}$ if storage in the City Delaware Basin Reservoirs is in the normal zone. The DRBC requested an additional $100 \mathrm{ft}^{3} / \mathrm{s}$ release from the New York City Reservoirs on a daily basis from October 5-9, 2007, for this purpose. A total of $500 \mathrm{ft}^{3} / \mathrm{s}$-days of water was released from Cannonsville Reservoir to temporarily augment the Trenton flows. 
From June 15 to November 30, 2007, the forecasted flow at Montague, exclusive of releases from the New York City reservoirs, was less than the flow objective on 108 days and releases were directed by the River Master. On 22 days during the June 15 to November 30 period, the observed flow was less than the flow objective. On 19 of these 22 days, observed flows were within 10 percent of the flow objective. Applicable design rates for the USGS gaging station Delaware River at Montague, New Jersey, are presented in table 6.

The total discharge observed at Montague, the portion derived from uncontrolled runoff from the drainage area below the reservoirs, the portion contributed by power reservoirs, and the portion contributed by Pepacton, Cannonsville, and Neversink Reservoirs from May to October are shown in figure 3. In developing the water budget for Montague, uncontrolled runoff was computed as the residual of observed flow minus releases and spills from all reservoirs, and, consequently, was subject to errors in observations, transit times, and routing of the various components of flow. The conservation release from Rio Reservoir is included in the uncontrolled runoff component. The net effect of these uncertainties is incorporated in the computation of uncontrolled runoff. From June 1 to November 30, 2007, diversions from the three New York City Delaware Basin reservoirs to Rondout Reservoir totaled 119.452 Bgal.

\section{Summary of Operations}

From December 1, 2006, to November 30, 2007, diversions from the three New York City reservoirs in the upper Delaware River Basin to Rondout Reservoir totaled 209.424 Bgal, and all releases from the three reservoirs to the Delaware River totaled 221.811 Bgal. River Master directed releases to the Delaware River from these reservoirs totaled 55.099 Bgal.

During the year, maximum storage in Pepacton Reservoir was 143.406 Bgal (102.3 percent of capacity) on April 17, 2007; 101.484 Bgal (106.0 percent of capacity) in Cannonsville Reservoir on March 28; and 35.983 Bgal (103.0 percent of capacity) in Neversink Reservoir on April 16. Maximum combined storage in the three reservoirs was 279.150 Bgal (103.1 percent of combined capacity) on April 20, 2007. The combined spill volume from the three reservoirs for the year was 102.145 Bgal.

During the report year, minimum storage in Pepacton Reservoir was 92.382 Bgal (65.9 percent of capacity) on October 19, 2007; 41.753 Bgal (43.6 percent of capacity) in Cannonsville Reservoir on October 11, 2007; and 22.591 Bgal (64.7 percent of capacity) in Neversink Reservoir on October 10, 2007. Minimum combined storage in the three reservoirs was $158.543 \mathrm{Bgal}$ (58.5 percent of combined capacity) on October 11, 2007.

On November 30, 2007, the end of the report year, combined storage in the three reservoirs was 216.317 Bgal or 79.9 percent of combined capacity. From December 1, 2006, to November 30, 2007, the net change in combined storage was $-54.326 \mathrm{Bgal}$, or a decrease equivalent to 20.1 percent of combined capacity.

Combined storage for the three reservoirs on the first day of the month was above median in every month from December to April and in November, and below median in every month from May to October (fig. 4). 


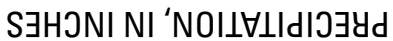

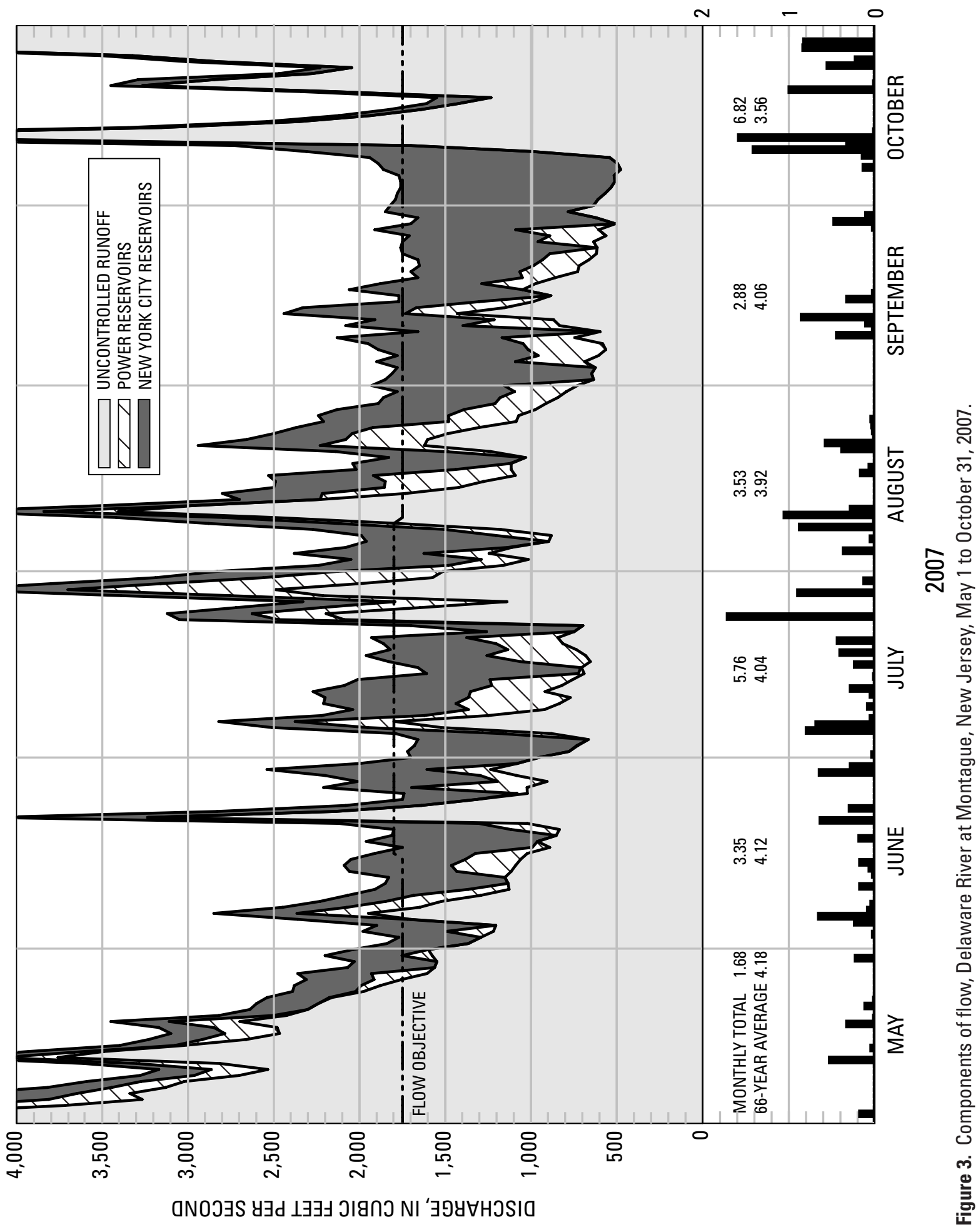




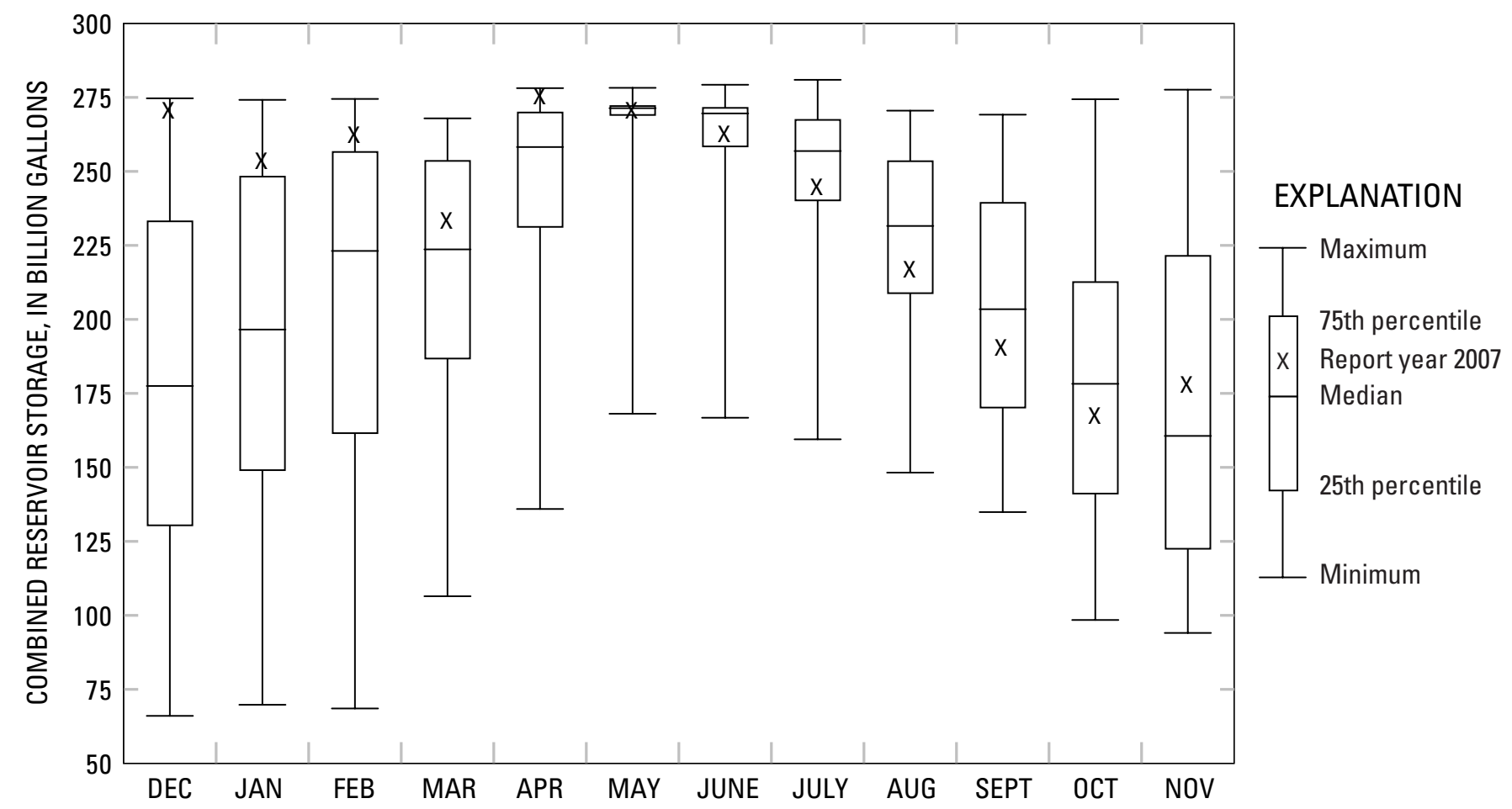

Figure 4. Combined storage in Pepacton, Cannonsville, and Neversink Reservoirs on the first day of the month, December 2006 to November 2007 (this report year), and summary statistics for the reference period, June 1967 to November 2006.

\section{Streamflow}

\section{Components of Flow, Delaware River at Montague, New Jersey}

The data and computations of the various components of flow form the basic operational records used by the River Master to carry out specific responsibilities related to the Montague formula. The operational record has two parts: forecasted flow at Montague, exclusive of controlled releases from New York City's reservoirs (table 8), and segregation of components of daily mean flow at Montague (table 9).

The following components may be present in the flow of the Delaware River at Montague:

1. Controlled releases from Lake Wallenpaupack on Wallenpaupack Creek, for the production of hydroelectric power.

2. Controlled releases from Rio Reservoir on Mongaup River, for the production of hydroelectric power.

3. Runoff from the uncontrolled area above Montague, including spills from New York City reservoirs, Lake Wallenpaupack, and Rio Reservoir.

4. Controlled releases from Pepacton, Cannonsville, and Neversink Reservoirs of New York City.

The releases from New York City's reservoirs necessary to meet the Montague flow objective were computed on the basis of the forecasted flow at Montague, exclusive of controlled releases from the City reservoirs. 


\section{Time of Travel}

Following are average times for the effective travel of water from the various sources of controlled supply to Montague, New Jersey. These times were used for flow routing during the 2007 report year.

\begin{tabular}{lc}
\hline \multicolumn{1}{c}{ Source } & $\begin{array}{c}\text { Travel time, } \\
\text { in hours }\end{array}$ \\
\hline Pepacton Reservoir & 60 \\
Cannonsville Reservoir & 48 \\
Neversink Reservoir & 33 \\
Lake Wallenpaupack & 16 \\
Rio Reservoir & 8 \\
\hline
\end{tabular}

Travel times were computed from reservoir and powerplant operations data and historical streamflow records. The travel times generally are suitable for use in the operations of the River Master. Occasionally, however, significant exceptions are observed. For example, when a large release from Cannonsville Reservoir follows a small release, a substantial portion of the water fills the channel en route, and the remainder may arrive at Montague as much as 66 hours after the time of release. During winter, the formation of ice, together with lower streamflow, gradually increases the resistance to water flow, resulting in increased travel times. Because ice-affected travel times increase gradually over several days, and releases were not directed to meet the Montague flow objective during periods of ice, no adjustments were made to compensate for increased travel times during these periods of the report year.

\section{Segregation of Flow at Montague}

The River Master daily operations record of reservoir releases and segregation of the various components contributing to the flow of the Delaware River at Montague, New Jersey, are presented in table 9. The data are arranged to conform to the downstream movement of water from the various sources to Montague. Summation of data across individual rows in the table is equivalent to routing the various flow contributions to Montague, using the above-noted average travel times. Uncontrolled runoff was computed as a residual by subtracting the flow contributions of all other sources from the observed discharge at Montague.

\section{Computation of Directed Releases}

During the report year, the River Master used the following information for daily operations: (1) discharges computed from recorded or reported stream gage heights, for various 24-hour periods, absent realtime information on any changes in stage-discharge relations; (2) daily discharge from New York City's three Delaware Basin reservoirs, measured with venturi meters; (3) precipitation reports for the previous 24 hours; (4) actual powerplant releases converted to daily discharges; (5) advance estimates of power demand converted to daily discharges; (6) advance estimates of uncontrolled runoff at Montague; and (7) average travel times for routing water from various sources. Although uncertainty is inherent in the advance estimates, this information is used by necessity in the daily design and direction of reservoir releases.

The 60-hour travel time of water from Pepacton Reservoir to Montague is greater than the travel time of water from any other reservoir in the upper Delaware River Basin. Releases from Cannonsville and Neversink Reservoirs were timed to arrive at Montague concurrently with releases from Pepacton Reser- 
voir. To allow for differences in travel times, daily directed releases were scheduled to begin from Pepacton Reservoir at 1200 hours, from Cannonsville Reservoir at 2400 hours, and from Neversink Reservoir at 1500 hours the following day.

Releases from the City's reservoirs required to meet the Montague flow objective were computed from forecasts of releases from Lake Wallenpaupack and Rio Reservoir, and estimates of uncontrolled runoff at Montague. To account for the travel times from these sources to Montague, the computation requires estimates of the following components of flow two or more days in advance: (1) releases from Lake Wallenpaupack; (2) releases from Rio Reservoir; and (3) uncontrolled runoff from the drainage area upstream of Montague. The River Master operations record for computing daily directed release requirements during periods of low flow is given in table 8 .

The electric utilities furnished forecasts of power generation and releases. Because the hydroelectric plants were used chiefly for area regulation or meeting peak power demands, the forecasts were subject to various modifying factors, including the vagaries of weather on electricity demand. In addition, because the power companies are members of regional transmission organizations, demand for power outside of the local service area may unexpectedly affect generation schedules. Consequently, at times, the actual use of water for power generation differs considerably from the forecasts used in the design of reservoir releases.

For computational purposes during periods of low flow, estimates of uncontrolled runoff at Montague were treated as two components: (1) current runoff and (2) forecasted increase in runoff from precipitation. Estimates of these components are given in table 8.

During ice-free conditions, current runoff was computed using a routing and recession procedure based on discharges at 0800 hours at the following USGS gaging stations:

\begin{tabular}{lc}
\hline \multicolumn{1}{c}{ Station Name } & $\begin{array}{c}\text { Drainage Area } \\
\left(\mathbf{m i}^{2}\right)\end{array}$ \\
\hline Beaver Kill at Cooks Falls, New York & 241 \\
Oquaga Creek at Deposit, New York & 67.6 \\
Equinunk Creek at Equinunk, Pennsylvania & 56.3 \\
Callicoon Creek at Callicoon, New York & 110 \\
Tenmile River at Tusten, New York & 45.6 \\
Lackawaxen River at Hawley, Pennsylvania & 290 \\
Shohola Creek near Shohola, Pennsylvania & 83.6 \\
Neversink River at Port Jervis, New York & 336 \\
\hline
\end{tabular}

During winter, the advance estimate of uncontrolled runoff (current conditions) was made on the basis of observed flows at a reduced network of gaging stations and the recession curve for computed uncontrolled flow at Montague.

The forecasted runoff from precipitation is shown in table 8 under the heading "Weather Adjustment." Throughout the year, the NWS office in Binghamton, New York, furnished quantitative forecasts of average precipitation and air temperatures for the 3,480- $\mathrm{mi}^{2}$ drainage basin upstream of Montague, New Jersey. During winter, runoff was estimated on the basis of the current status of snow and ice, along with forecasted precipitation and temperature. During other periods, forecasted precipitation was used to estimate runoff. 
The forecasted flow at Montague, exclusive of releases from New York City's Delaware Basin reservoirs (table 8), is computed as the sum of forecasted releases from power reservoirs, estimated uncontrolled runoff including conservation releases from Rio Reservoir, and weather adjustments. If the computed total flow is less than the flow objective at Montague, then the deficiency is made up by releases from the City's reservoirs, as directed by the River Master.

When forecasts of precipitation or powerplant releases were revised appreciably after a release was directed, the release required from the City's reservoirs was recomputed. Commonly, this procedure resulted in a reduced release requirement for New York City reservoirs for that day. Only final figures for releases from New York City reservoirs are given in table 8.

\section{Analysis of Forecasts}

Forecasts of streamflow at Montague, developed on the basis of anticipated contributions from the components described previously but excluding releases from New York City's reservoirs, differed on most days from observed flow. Occasionally, variations in the components were partially compensating and observed flows compared favorably with forecasted flows.

The forecasted flow of the Delaware River at Montague, exclusive of releases from the New York City reservoirs, was less than the flow objective on most days from May 27 to October 13, 2007. The following tabulation compares estimates of three components of flow at Montague with actual flow during this period.

\begin{tabular}{lcc}
\hline Releases and Runoff & $\begin{array}{c}\text { Forecasted } \\
\text { flow } \\
{\left[\left(\mathbf{f t}^{3} / \mathbf{s}\right)-\mathbf{d}\right]}\end{array}$ & $\begin{array}{c}\text { Actual } \\
\text { flow } \\
{\left[\left(\mathbf{f t}^{3} / \mathbf{s}\right)-\mathbf{d}\right]}\end{array}$ \\
\hline Power releases & & \\
$\quad$ Lake Wallenpaupack & 31,362 & 36,093 \\
$\quad$ Rio Reservoir & 856 & 928 \\
Runoff from uncontrolled area & 132,470 & 164,438 \\
\hline
\end{tabular}

From May 27 to October 13, actual releases from Lake Wallenpaupack averaged 15 percent greater than forecasted releases, and actual and forecasted releases from Rio Reservoir were $0 \mathrm{ft}^{3} / \mathrm{s}$ on most days. Observed runoff from the uncontrolled area was about 24 percent greater than forecasted runoff.

On any given day, forecasted releases and actual releases can differ considerably. The ranges of actual daily releases from May 27 to October 13, 2007, are as follows: daily releases at Lake Wallenpaupack differed from forecasted releases by $155 \mathrm{ft}^{3} / \mathrm{s}$ less to $1,211 \mathrm{ft}^{3} / \mathrm{s}$ greater, and daily releases at Rio Reservoir differed from forecasted releases by $270 \mathrm{ft}^{3} / \mathrm{s}$ less to $195 \mathrm{ft}^{3} / \mathrm{s}$ greater. On the basis of observed flows at Montague, total directed releases from New York City's Delaware Basin reservoirs during the report year were about 18 percent more than required for exact forecasting.

Comparison of hydrographs of forecasted daily runoff and observed daily runoff from the uncontrolled area (fig. 5) indicates that the forecasts generally were suitable for use in designing releases from New York City's Delaware Basin reservoirs. Numerical adjustments to the designs were made when needed to 


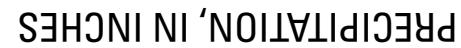

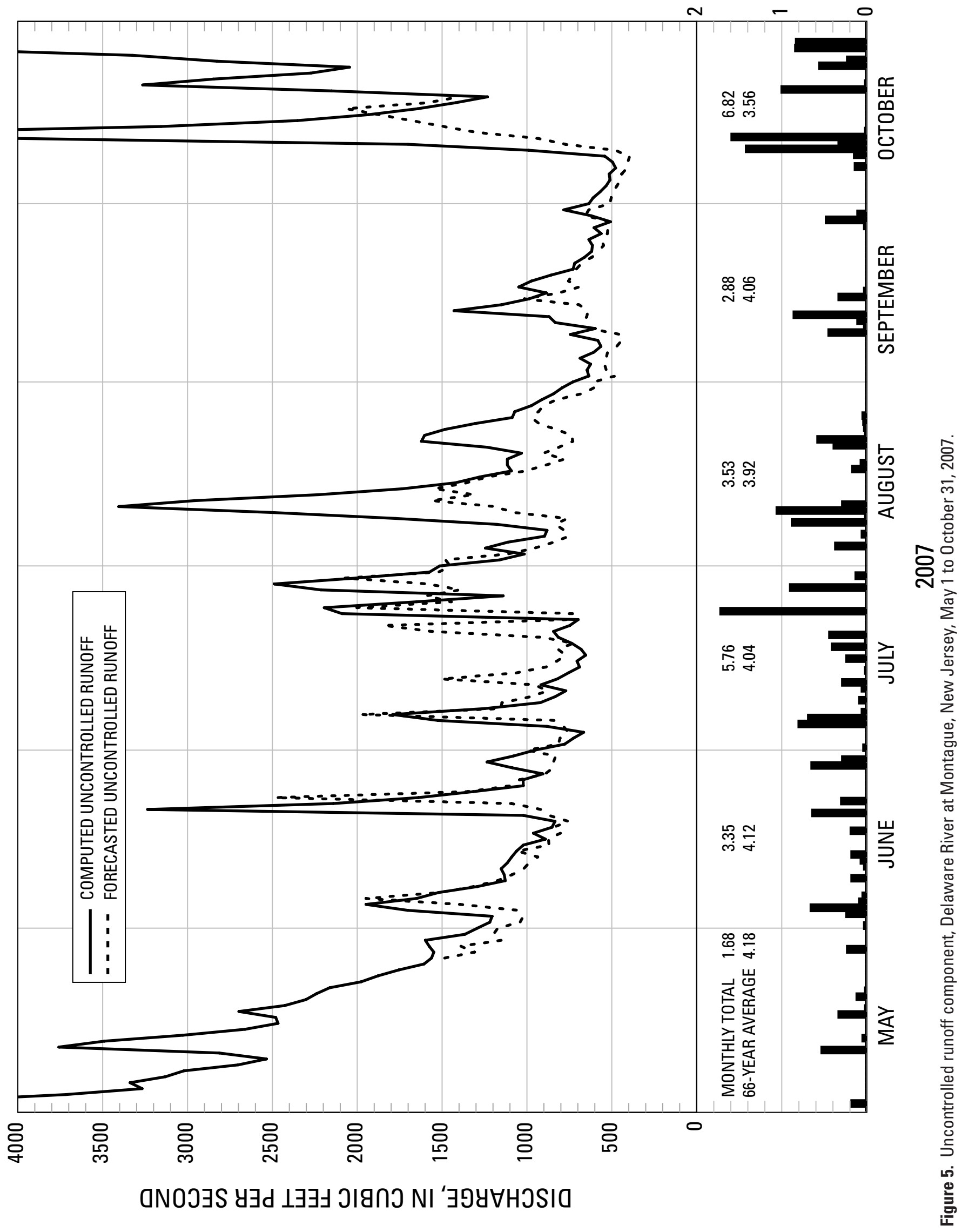


compensate for errors in the forecasts, but, because of travel times, the effects of the adjustments on flows at Montague were not evident until several days after the design date.

Analysis of the precipitation forecasts shows that the total precipitation amount forecasted for the 3-day design periods is reasonably accurate, but often the actual timing of precipitation events may be earlier or later than forecasted. The accuracy of the runoff forecasts is affected greatly by the timing of precipitation events. In addition, if the actual storm track differs from the forecasted track, the amount and timing of runoff can be substantially different than predicted.

\section{Diversions to New York City Water Supply}

The 1954 Amended Decree authorizes New York City to divert water from the Delaware River Basin at a rate not to exceed the equivalent of $800 \mathrm{Mgal} / \mathrm{d}$. The Decree stipulates that the diversion rate shall be computed as the aggregate total diversion beginning June 1 of each year divided by the number of days elapsed since the preceding May 31.

Daily diversions during the report year from Pepacton, Cannonsville, and Neversink Reservoirs to the New York City water-supply system (Rondout Reservoir) are given in table 10. A running account of the average rates of combined diversions from the three reservoirs, computed as stipulated by the Decree, also is shown. The following tabulation shows allowable maximum diversion rates and average actual diversions for various periods during the report year.

\begin{tabular}{lcc}
\hline \multicolumn{1}{c}{ Effective dates } & $\begin{array}{c}\text { Allowable diversion } \\
\text { (Mgal/d) }\end{array}$ & $\begin{array}{c}\text { Average } \\
\text { actual diversion } \\
\text { (Mgal/d) }\end{array}$ \\
\hline December 1, 2006 to May 31, 2007 & 800 & 494 \\
June 1 to November 30, 2007 & 800 & 653 \\
\hline
\end{tabular}

During the report year, a total of 209.424 Bgal of water was diverted to the New York City watersupply system. The allowable diversion was 359.500 Bgal. 


\section{Storage in New York City Reservoirs}

The following tabulation summarizes the "point of maximum depletion" and other pertinent levels and contents of Pepacton, Cannonsville, and Neversink Reservoirs. This information was provided by the New York City Board of Water Supply.

\begin{tabular}{|c|c|c|c|c|c|c|}
\hline \multirow[b]{2}{*}{ Level } & \multicolumn{2}{|c|}{ Pepacton Reservoir } & \multicolumn{2}{|c|}{ Cannonsville Reservoir } & \multicolumn{2}{|c|}{ Neversink Reservoir } \\
\hline & $\begin{array}{l}\text { Elevation } \\
(\mathrm{ft})\end{array}$ & $\begin{array}{c}\text { Contents } \\
\text { (Bgal) }\end{array}$ & $\begin{array}{l}\text { Elevation } \\
\text { (ft) }\end{array}$ & $\begin{array}{c}\text { Contents } \\
\text { (Bgal) }\end{array}$ & $\begin{array}{c}\text { Elevation } \\
\text { (ft) }\end{array}$ & $\begin{array}{c}\text { Contents } \\
\text { (Bgal) }\end{array}$ \\
\hline $\begin{array}{l}\text { Full pool or } \\
\text { spillway crest }\end{array}$ & $1,280.00$ & $* 140.190$ & $1,150.00$ & *95.706 & $1,440.00$ & $* 34.941$ \\
\hline $\begin{array}{l}\text { Point of maxi- } \\
\text { mum depletion }\end{array}$ & $1,152.00$ & $* 3.511$ & $1,040.00$ & $* 1.020$ & $1,319.00$ & $* 0.525$ \\
\hline $\begin{array}{l}\text { Sill of diversion } \\
\text { tunnel }\end{array}$ & $1,143.00$ & $* 4.200$ & $+1,035.00$ & $* 1.564$ & $1,314.00$ & \\
\hline $\begin{array}{l}\text { Sill of river } \\
\quad \text { outlet tunnel }\end{array}$ & $1,126.50$ & & $1,020.50$ & & $1,314.00$ & \\
\hline Dead storage & & 1.800 & & 0.328 & & 1.680 \\
\hline
\end{tabular}

Daily storage in Pepacton, Cannonsville, and Neversink Reservoirs, above the "point of maximum depletion" or minimum full-operating level, is given in tables 3,4 , and 5 .

On December 1, 2006, combined storage in the three reservoirs was 270.220 Bgal, or 99.8 percent of combined capacity. Combined storage remained high throughout the winter, declined seasonally during the summer, and increased steadily in late fall. The three reservoirs spilled a total of $102.145 \mathrm{Bgal}$ during the year. Combined storage reached a maximum for the report year on April 20, 2007, at 279.150 Bgal. Combined storage was 216.317 Bgal, or 79.9 percent of combined capacity, on November 30, 2007.

\section{Comparison of River Master Operations Data With Other Streamflow Records}

River Master operations are conducted on a day-to-day basis and, by necessity, use preliminary data on streamflow. In this section, records used in River Master operations are compared to final data published for selected USGS gaging stations. Data on releases were reported in million gallons per day and converted to cubic feet per second for use in the comparisons.

\section{Releases from New York City Reservoirs}

River Master operations data on controlled releases from Pepacton, Cannonsville, and Neversink Reservoirs to the Delaware River were furnished by the New York City Department of Environmental Protection. These data were obtained from calibrated instruments connected to venturi meters installed in the outlet conduits of the reservoirs.

The USGS gaging station on East Branch Delaware River at Downsville, New York, is 0.5 mile downstream from Downsville Dam (fig. 1). Discharge measured at this station includes releases from Pepacton 
Reservoir and a small amount of seepage and any runoff that enters the channel between the dam and the gaging station. The drainage area is $371 \mathrm{mi}^{2}$ at the dam and $372 \mathrm{mi}^{2}$ at the gaging station.

The following tabulation compares releases from Pepacton Reservoir (table 9), reported by New York City, to the final records for the USGS gaging station on East Branch Delaware River at Downsville, New York (table 11), for the flow objectives shown.

\begin{tabular}{ll|c|c|c}
\hline Flow objective $\left(\mathrm{ft}^{3} / \mathrm{s}\right)$ & 60 & 85 & 185 & 700 \\
Number of USGS daily mean discharge values used in comparison & 42 & 16 & 36 & 43 \\
New York City-measured mean flow $\left(\mathrm{ft}^{3} / \mathrm{s}\right)$ & 60.7 & 84.8 & 185 & 699 \\
USGS-computed mean flow $\left(\mathrm{ft}^{3} / \mathrm{s}\right)$ & 56.7 & 76.4 & 172 & 696 \\
Percent difference & +7.1 & +11.0 & +7.6 & +0.4 \\
\hline
\end{tabular}

The differences at the four flow objectives do not exceed 11 percent. The instruments connected to the venturi meters were recalibrated periodically by New York City to improve the accuracy of the recorded flow data.

The USGS gaging station on West Branch Delaware River at Stilesville, New York, is 1.4 miles downstream from Cannonsville Dam (fig. 1). Discharge measured at this station includes releases from Cannonsville Reservoir and runoff from $2 \mathrm{mi}^{2}$ of drainage area between the dam and the gaging station. The drainage area is $454 \mathrm{mi}^{2}$ at the dam and $456 \mathrm{mi}^{2}$ at the gaging station. The gaging-station records are rated fair at flows greater than $100 \mathrm{ft}^{3} / \mathrm{s}$ and poor at flows less than $100 \mathrm{ft}^{3} / \mathrm{s}$. A rating of "fair" means that about 95 percent of the daily discharges are within 15 percent of the true discharge, whereas a rating of "poor" means that daily discharges have less than "fair" accuracy. The records include runoff from the area between the dam and the gaging station, and seepage near the base of the dam. The final discharge record for the USGS gaging station on West Branch Delaware River at Stilesville, New York, is presented in table 12 .

The USGS gaging station on Neversink River at Neversink, New York, is 1,650 ft downstream from Neversink Dam (fig. 1). Discharge measured at this station includes releases from Neversink Reservoir and, during storms, a small amount of runoff that originates between the dam and the gaging station. The drainage area is $92.5 \mathrm{mi}^{2}$ at the dam and $92.6 \mathrm{mi}^{2}$ at the gaging station.

The following tabulation compares releases from Neversink Reservoir (table 9), reported by New York City, to the final records for the USGS gaging station on Neversink River at Neversink, New York (table 13), for the flow objectives shown.

\begin{tabular}{llllrr}
\hline Flow objective $\left(\mathrm{ft}^{3} / \mathrm{s}\right)$ & 45 & 70 & 85 & 130 & 190 \\
Number of USGS daily mean discharge values used in comparison & 40 & 10 & 69 & 14 & 18 \\
New York City-measured mean flow $\left(\mathrm{ft}^{3} / \mathrm{s}\right)$ & 44.9 & 69.6 & 85.1 & 131 & 190 \\
USGS-computed mean flow $\left(\mathrm{ft}^{3} / \mathrm{s}\right)$ & 45.3 & 67.8 & 84.3 & 120 & 177 \\
Percent difference & -0.9 & +2.7 & +0.9 & +9.2 & +7.3 \\
\hline
\end{tabular}

The differences at all flow objectives are less than 10 percent. 


\section{Delaware River at Montague, New Jersey}

The River Master's operations record for the Delaware River at Montague, New Jersey (table 9), showed 0.1 percent less discharge for the report year than the published USGS record for the gaging station (table 14). Daily values for the two records were in good agreement, except during ice-affected periods and in June.

\section{Diversion Tunnels}

Records of diversions through the East Delaware, West Delaware, and Neversink Tunnels (fig. 1) were furnished by the New York City Department of Environmental Protection. These records were obtained from the City's calibrated instruments connected to venturi meters installed in the tunnel conduits. The measured flows were transmitted electronically on a 15-second interval to a City computer and, on 5-minute intervals, release and diversion quantities for the preceding 5-minute period were computed using the instantaneous rate-of-flow data from each instrument. These 5-minute quantities were then summed to compute daily total flows, which were reported to the River Master's office on a daily basis. On a weekly basis, the diversion figures were checked against the flow meter totalizer readings and corrected when necessary.

The East Delaware Tunnel is used to divert water from Pepacton Reservoir to Rondout Reservoir. Conditions in the outlet channel of the East Delaware Tunnel were unfavorable for flow measurements during the report year because of high water levels in Rondout Reservoir.

The hydroelectric powerplant at the downstream end of the East Delaware Tunnel operated most days of the report year. When the powerplant was not in operation, some water leaked through the wicket gates and was not recorded on the totalizer. A current-meter measurement made in 1989 shows that the (assumed constant) rate of leakage is about $8.0 \mathrm{Mgal} / \mathrm{d}$. Because the powerplant was not in operation for the equivalent of 56 days during the 2007 report year, the estimated quantity of unmeasured leakage was about 0.4 Bgal.

The West Delaware Tunnel is used to divert water from Cannonsville Reservoir to Rondout Reservoir. Inspections of the channel below the outlet, when valves were closed, revealed only negligible leakage. A hydroelectric powerplant uses water diverted through the West Delaware Tunnel, but the plant operates only when diversions are less than $300 \mathrm{Mgal} / \mathrm{d}$. When the powerplant is not operating, the valves on the pipelines to the plant are closed, and there is no leakage through the system.

The Neversink Tunnel is used to divert water from Neversink Reservoir to Rondout Reservoir. A hydroelectric powerplant uses water diverted through the Neversink Tunnel. When the powerplant is not operating and the main valve on the diversion tunnel is open, leakage develops that is not recorded on the venturi instruments. One current-meter measurement made in 1999 showed a leakage rate of $16.2 \mathrm{ft}^{3} / \mathrm{s}$ $(10.5 \mathrm{Mgal} / \mathrm{d})$. When the powerplant is operating, the leakage is included in the recorded flow. No leakage occurs when the main valve on the tunnel is closed. During the 2007 report year, the powerplant did not operate on most days and was not operated the equivalent of 273 days. Using the leakage rate noted above and records of powerplant operation, about 2.9 Bgal of water was diverted but not recorded. 


\section{Diversions by New Jersey}

The Amended Decree authorizes New Jersey to divert water from the Delaware River and its tributaries in New Jersey, to areas outside of the Delaware River Basin, without compensating releases. These diversions may not exceed $100 \mathrm{Mgal} / \mathrm{d}$ as a monthly average, and the daily mean diversion may not exceed $120 \mathrm{Mgal} / \mathrm{d}$. The USGS gaging station on Delaware and Raritan Canal at Port Mercer, New Jersey (fig. 1), is used as the official control point for measuring diversions by New Jersey (table 15).

The following tabulation shows the allowable diversion by New Jersey, the period it was in effect, and the maximum monthly diversion during the report year.

\begin{tabular}{lccc}
\hline Effective dates & $\begin{array}{c}\text { Allowable monthly } \\
\text { average diversion } \\
\text { (Mgal/d) }\end{array}$ & $\begin{array}{c}\text { Maximum monthly } \\
\text { average diversion } \\
\text { (Mgal/d) }\end{array}$ & $\begin{array}{c}\text { Month of maximum } \\
\text { average diversion }\end{array}$ \\
\hline Dec. 1, 2006 to Nov. 30, 2007 & 100 & 96.7 & February \\
\hline
\end{tabular}

The maximum daily mean diversion was 104 Mgal on February 21, 2007. Diversions by New Jersey did not exceed the limits stipulated by the Decree.

\section{Conformance of Operations Under the Amended Decree of the U.S. Supreme Court Entered June 7, 1954}

From December 1, 2006, to November 30, 2007, operations of the Delaware River Master were conducted as stipulated by the Decree.

Diversions from the Delaware River Basin to the New York City water-supply system did not exceed those authorized by the Decree. Under compensating releases of the Montague Formula, New York City released water from its reservoirs at rates designed by the River Master to meet the applicable flow objectives at Montague, New Jersey. During the report year, New York City complied fully with all directives and requests of the River Master.

Diversions from the Delaware River Basin by New Jersey were within limits stipulated by the Decree. New Jersey complied fully with all directives and requests of the River Master. 
Table 1. Precipitation in the Delaware River Basin above Montague, New Jersey.

(Source: National Weather Service, New York City Department of Environmental Protection, and Office of the Delaware River Master)

[All values, except percentages, in inches]

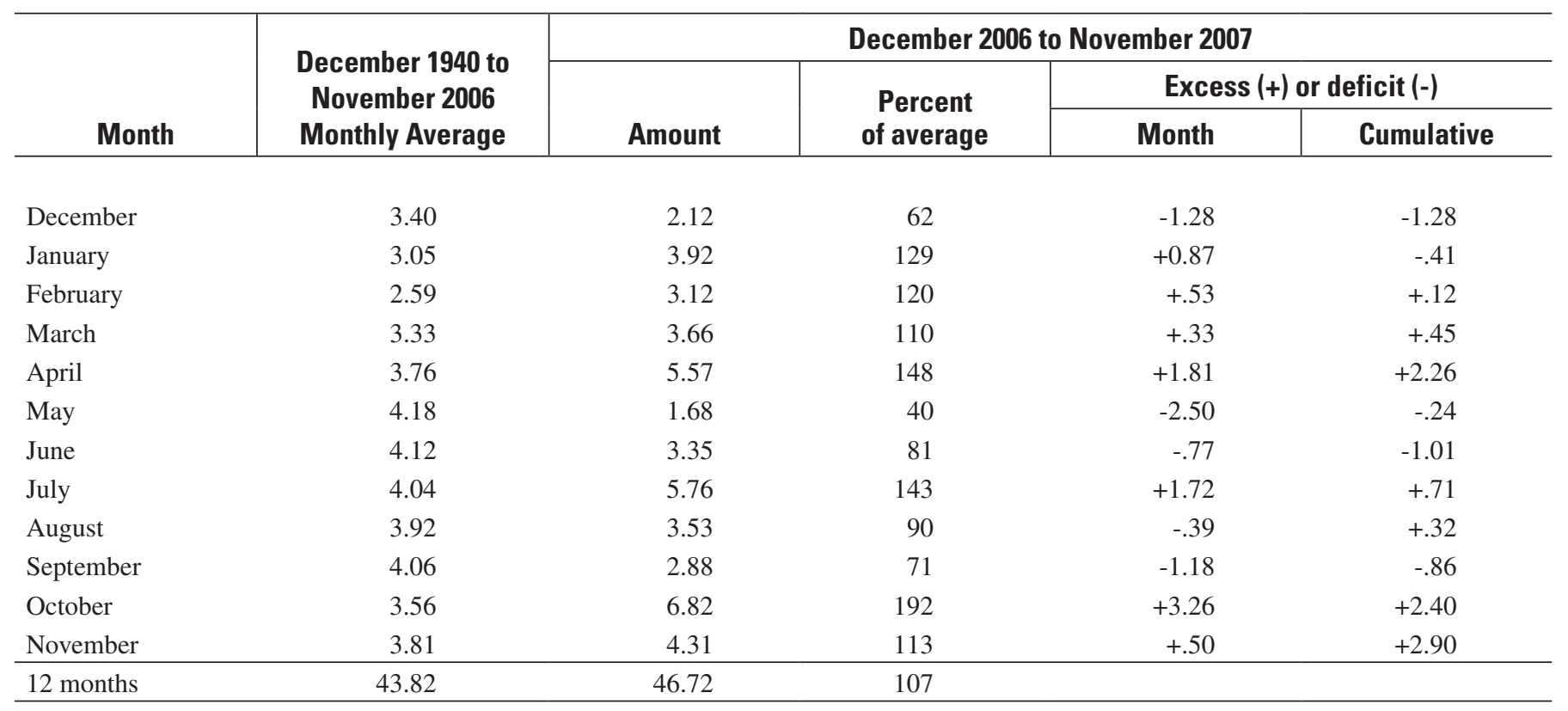

Table 2. Conservation release rates for New York City reservoirs in the Delaware River Basin.

[Source: DRBC Docket No. D-77-20 CP (Revision 7)]

[All values in cubic feet per second]

\begin{tabular}{|c|c|c|c|c|c|}
\hline Reservoir & Effective dates & \multicolumn{4}{|c|}{ Conservation release rates } \\
\hline Pepacton & December 1 to November 30 & 35 & 30 & 25 & 19 \\
\hline \multirow[t]{2}{*}{ Cannonsville } & December 1 to May 31 & 45 & 38 & 32 & 23 \\
\hline & June 1 to August 31 & 60 & 51 & 43 & 23 \\
\hline Neversink & December 1 to November 30 & 25 & 21 & 18 & 15 \\
\hline
\end{tabular}




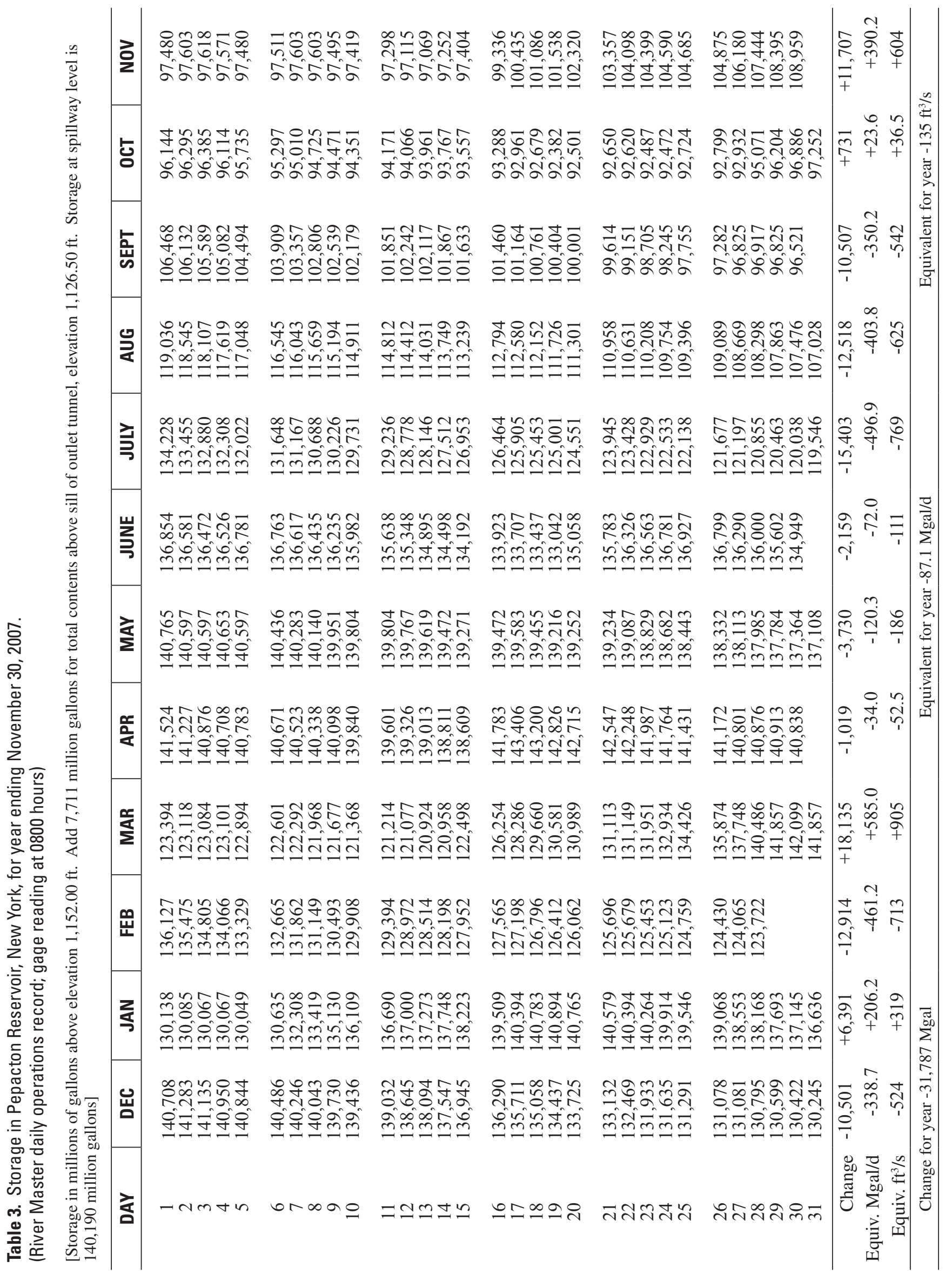




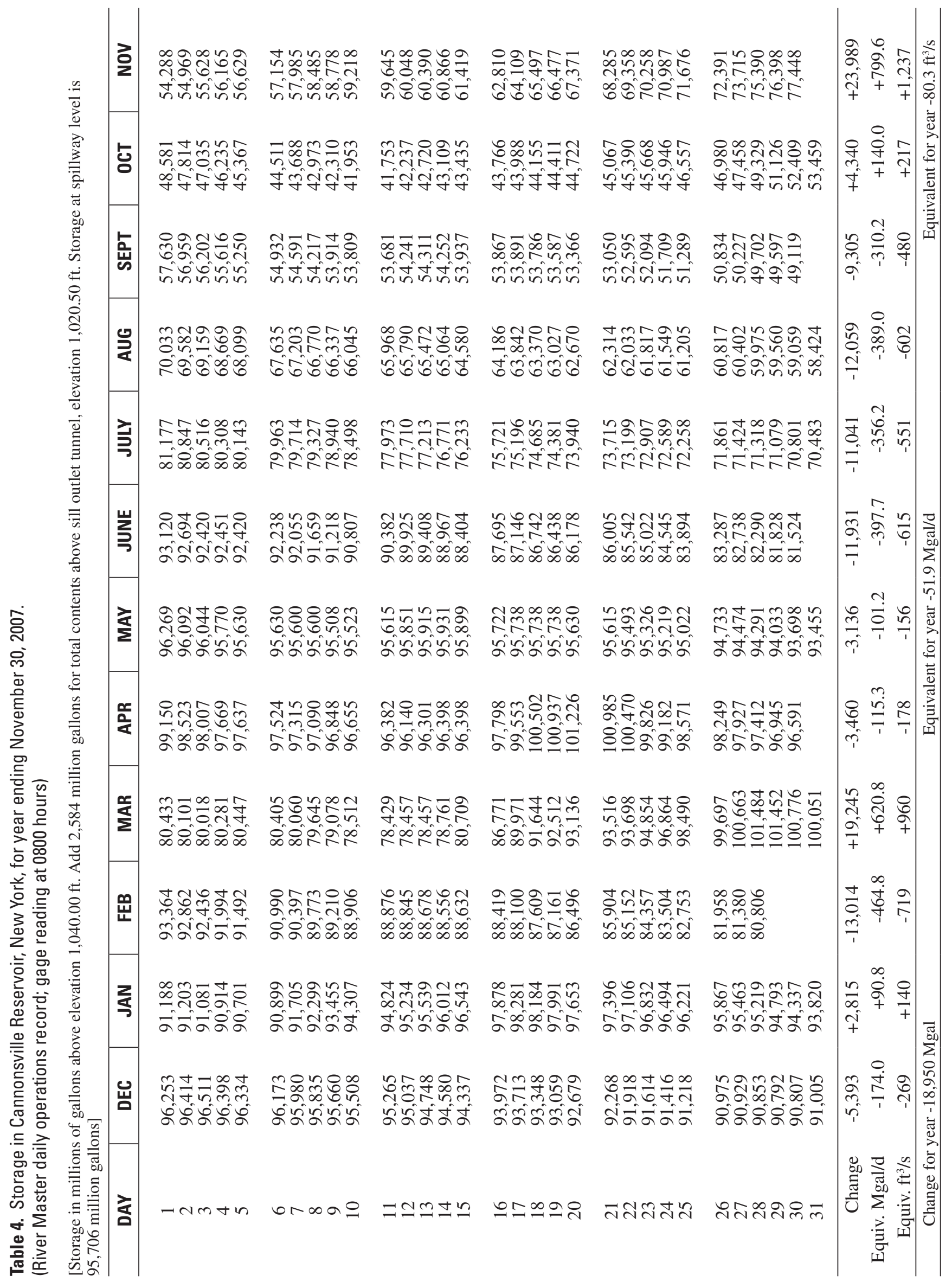




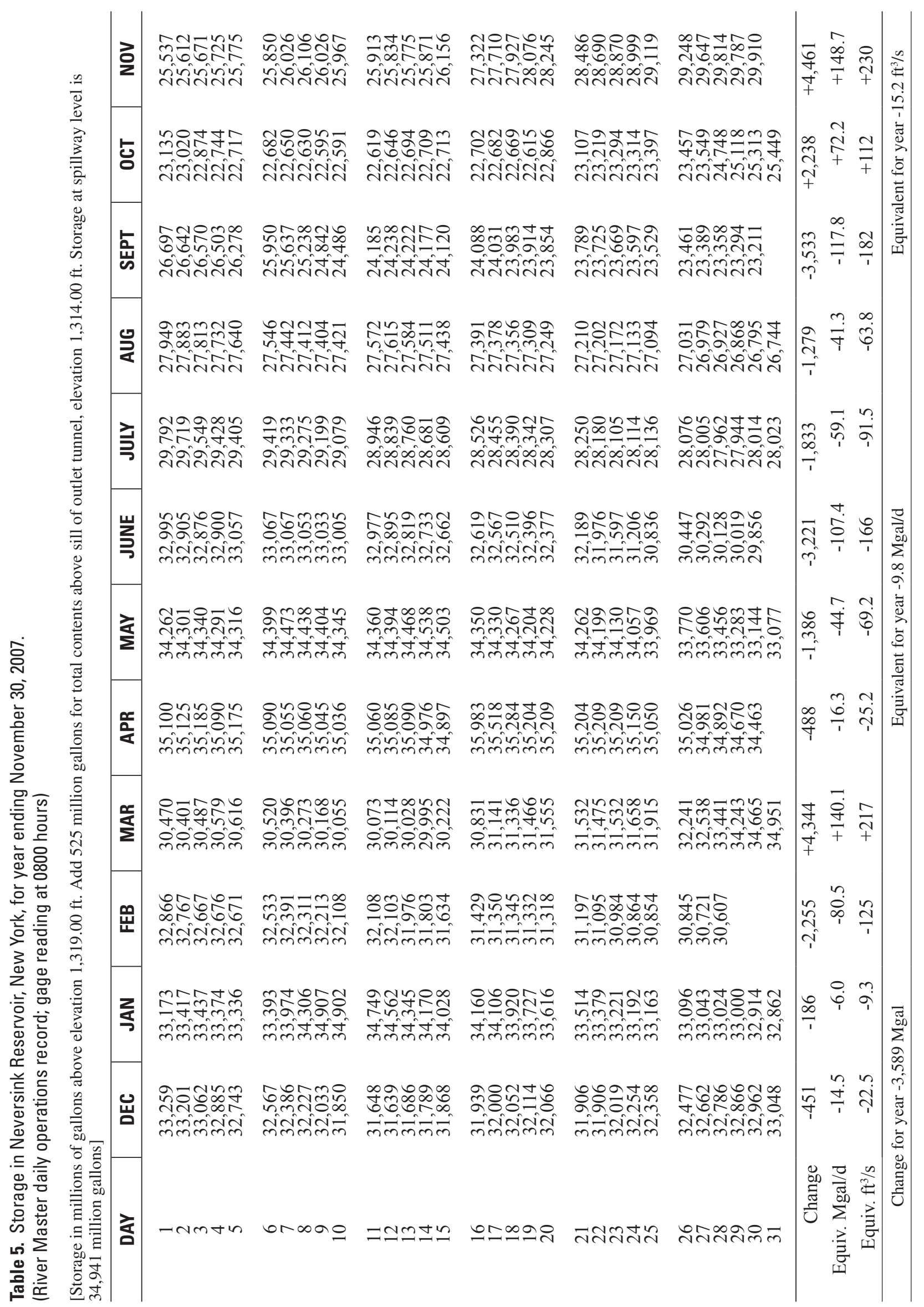


Table 6. Design rates for Delaware River at Montague, New Jersey, gaging station, December 1, 2006, to November 30, 2007. (Source: Office of the Delaware River Master)

[Rates in cubic feet per second]

\begin{tabular}{l|c}
\multicolumn{1}{c|}{ Effective dates } & Montague Design Rate \\
\hline December 1, 2006 to June 14, 2007 & 1,750 \\
June 15 to August 9, 2007 & 1,800 \\
August 10 to November 30, 2007 & 1,750 \\
\hline
\end{tabular}


Table 7. Consumption of water by New York City, 1950 to 2007.

(Source: New York City Department of Environmental Protection, Bureau of Water Supply)

[Mgal/d, million gallons per day; Bgal, billion gallons]

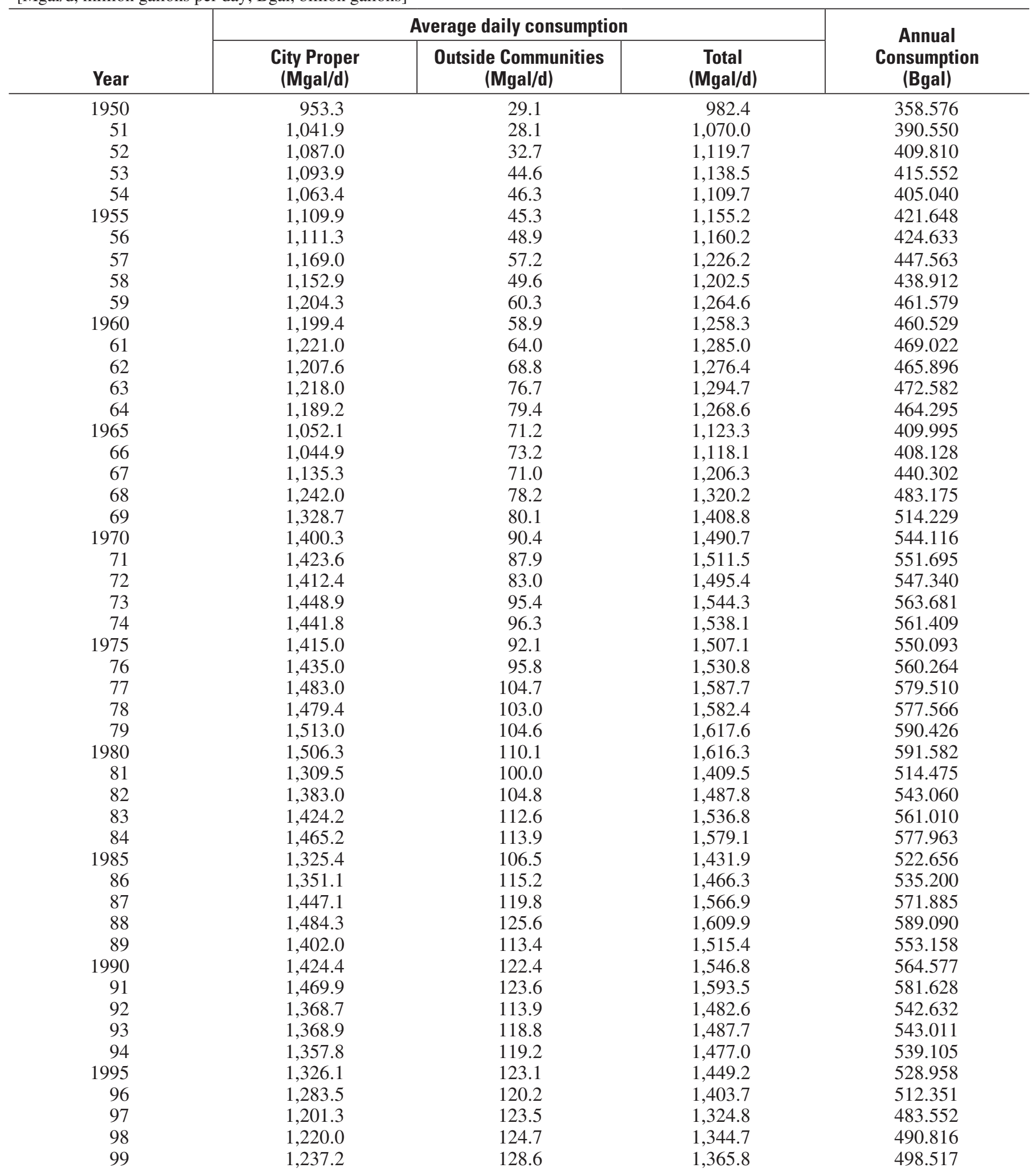


Table 7. Consumption of water by New York City, 1950 to 2007.-Continued

(Source: New York City Department of Environmental Protection, Bureau of Water Supply)

[Mgal/d, million gallons per day; Bgal, billion gallons]

\begin{tabular}{r|c|c|c|c}
\hline \multirow{2}{*}{ Year } & \multicolumn{3}{|c|}{ Average daily consumption } & \multirow{2}{*}{$\begin{array}{c}\text { Annual } \\
\text { Consumption } \\
\text { (Bgal) }\end{array}$} \\
\cline { 2 - 4 } & $\begin{array}{c}\text { City Proper } \\
\text { (Mgal/d) }\end{array}$ & $\begin{array}{c}\text { Outside Communities } \\
\text { (Mgal/d) }\end{array}$ & $\begin{array}{c}\text { Total } \\
\text { (Mgal/d) }\end{array}$ & 499.700 \\
2000 & $1,240.4$ & 124.9 & $1,365.3$ & 479.026 \\
01 & $1,184.0$ & 128.4 & $1,312.4$ & 458.696 \\
02 & $1,135.6$ & 121.1 & $1,256.7$ & 441.516 \\
03 & $1,093.7$ & 115.9 & $1,209.6$ & 449.461 \\
04 & $1,099.6$ & 117.5 & $1,217.1$ & 449.462 \\
2005 & $1,107.6$ & 123.8 & $1,231.4$ & 432.890 \\
06 & $1,069.2$ & 116.8 & $1,186.0$ & 451.505 \\
\hline
\end{tabular}




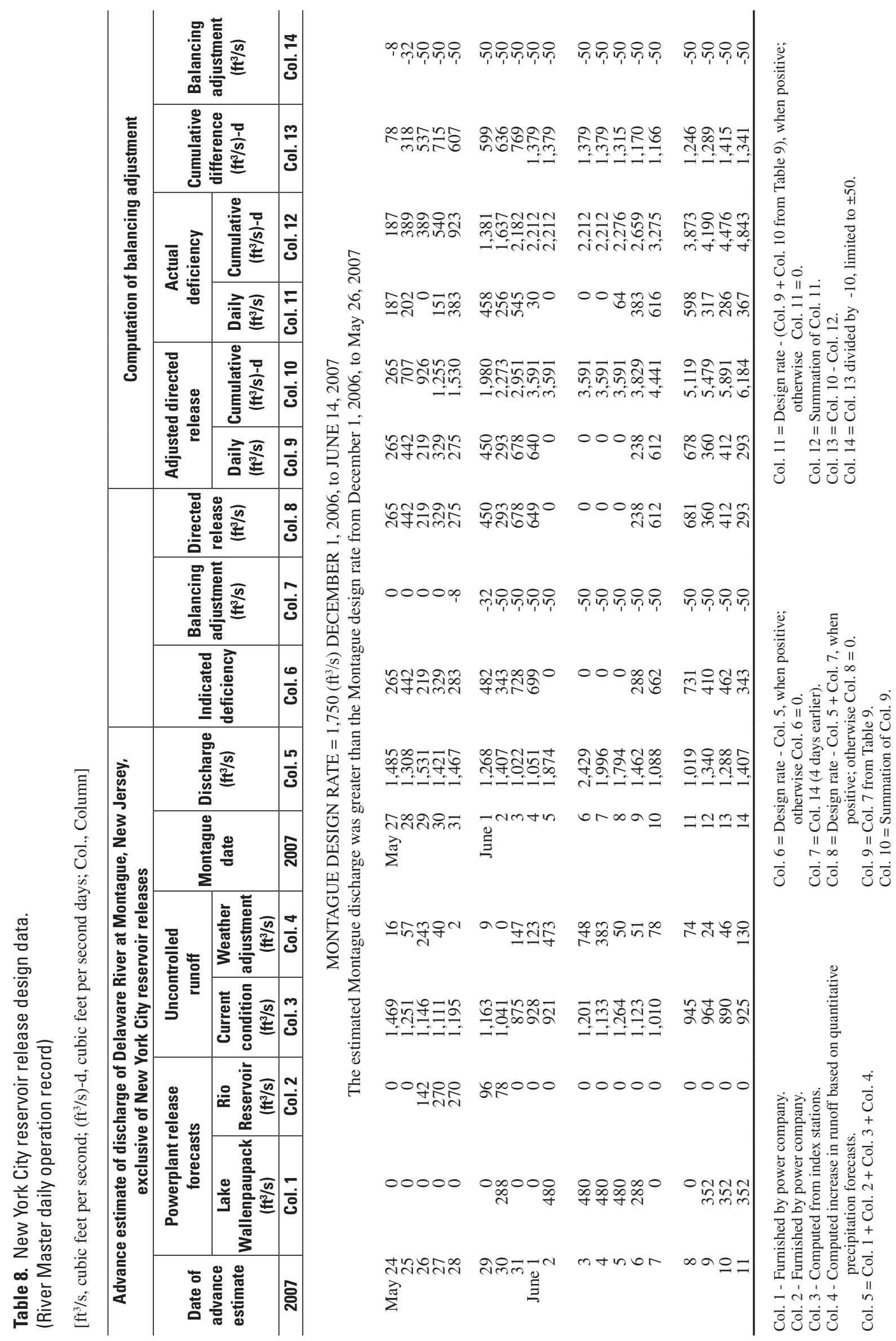




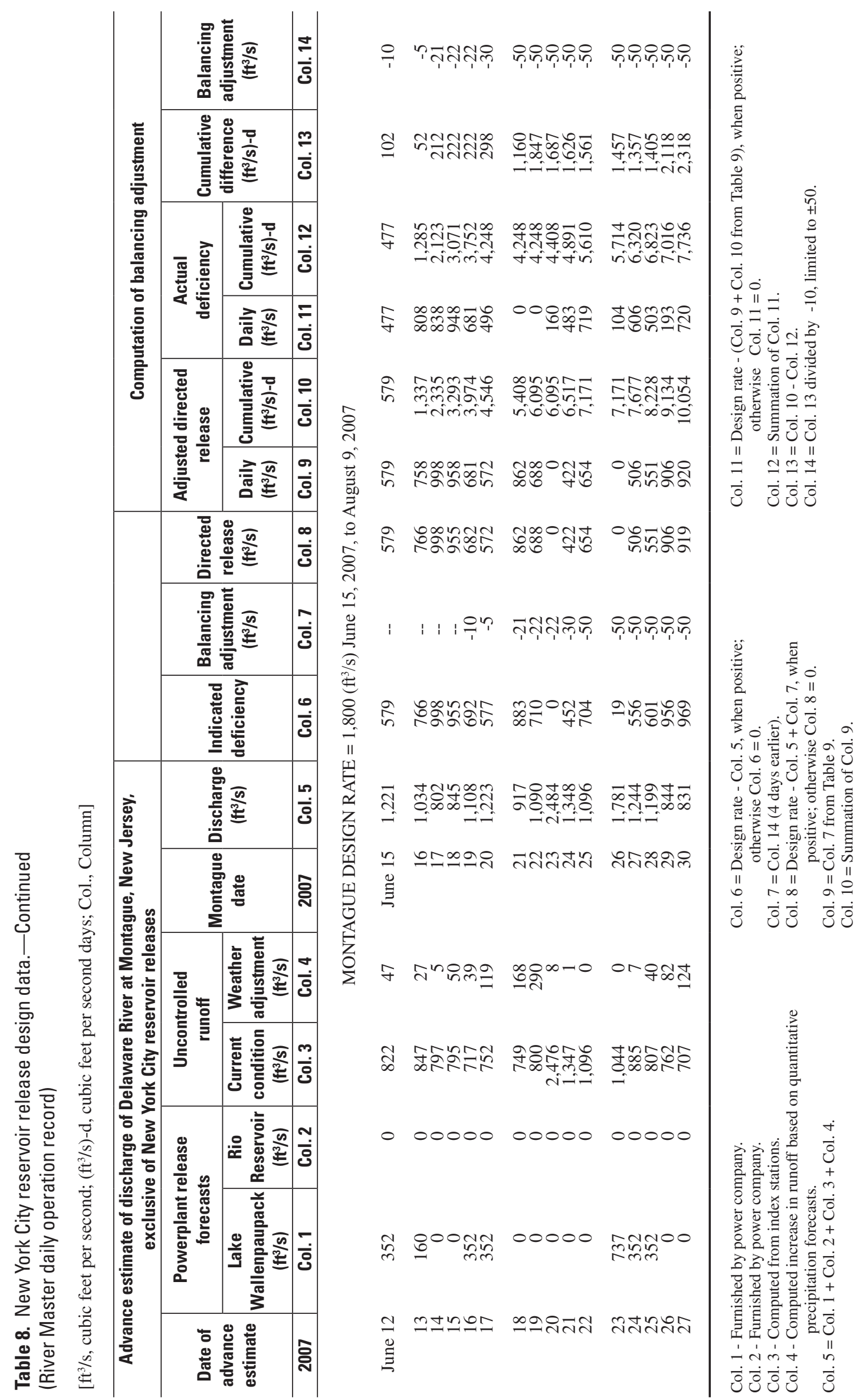




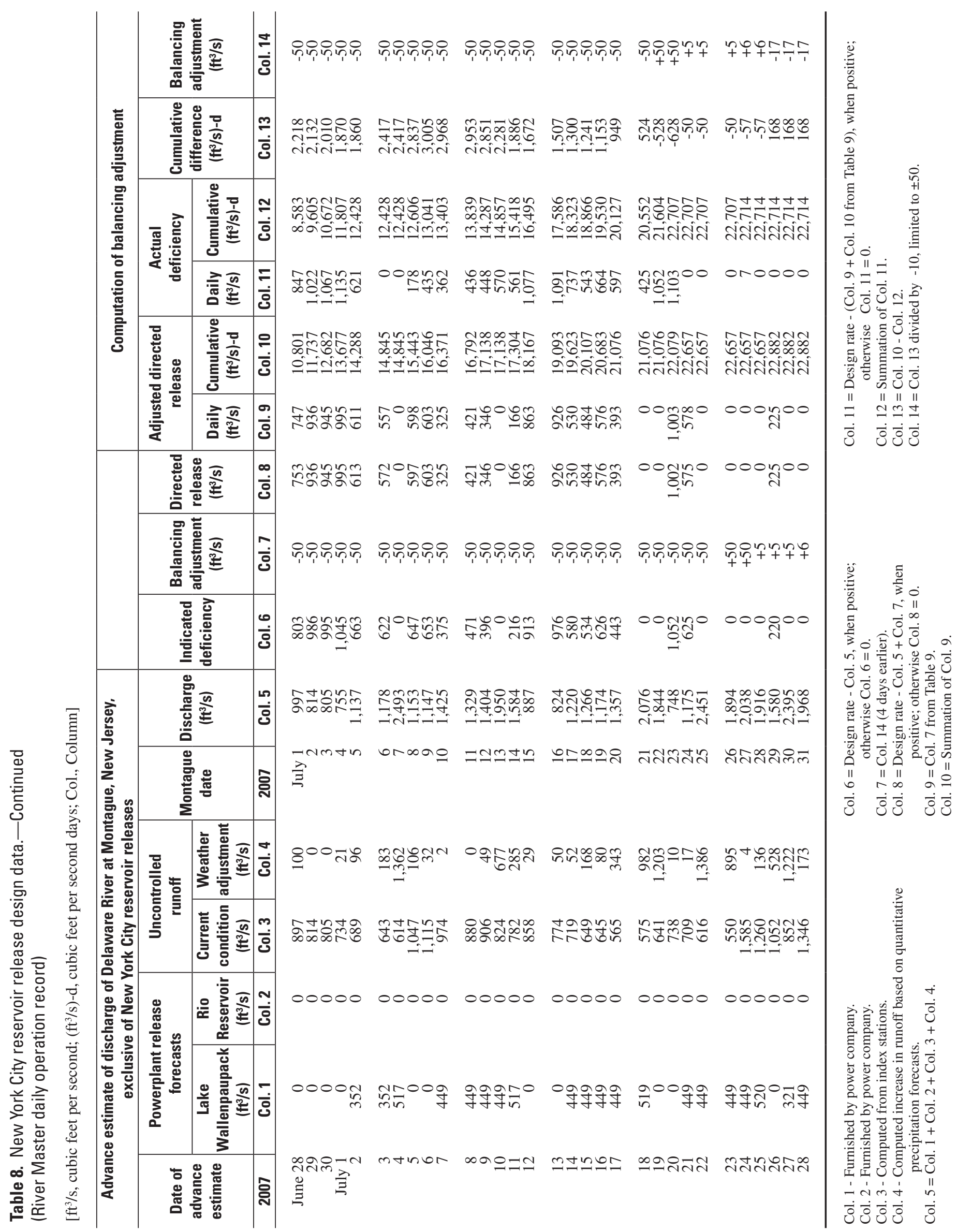




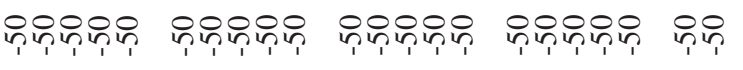

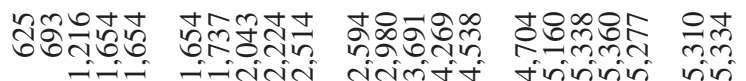

00000 ooo스

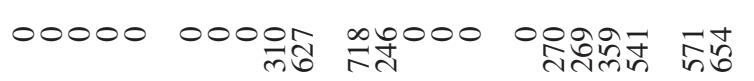

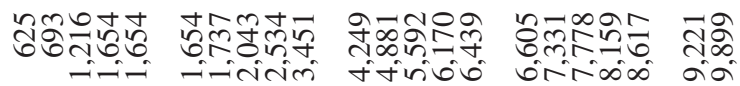

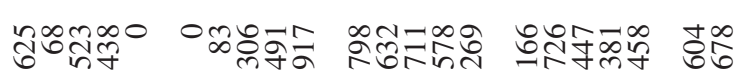

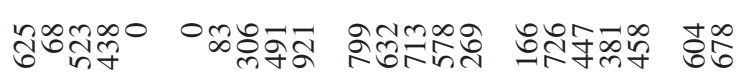

1 1 1 i n

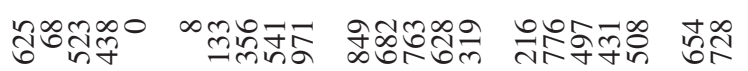

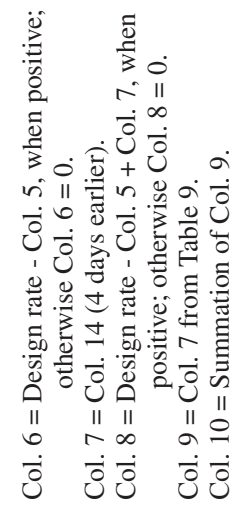

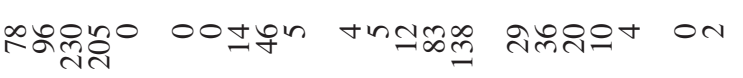

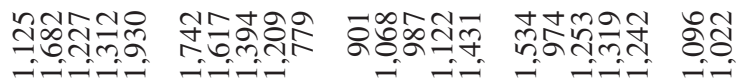

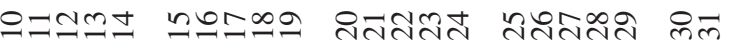

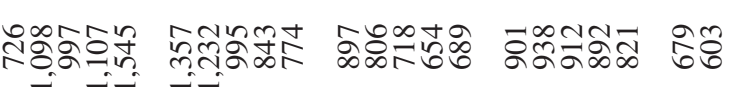

0000000000000000000000

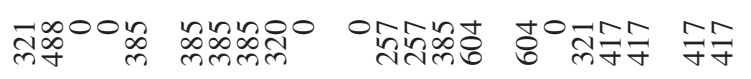

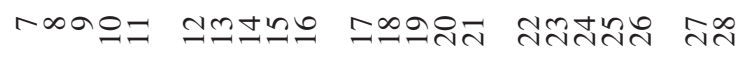

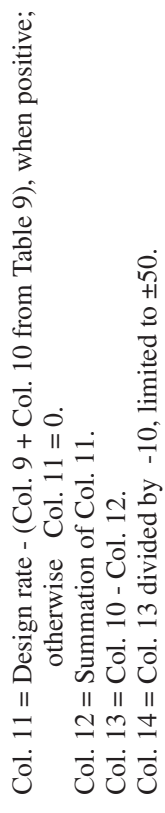




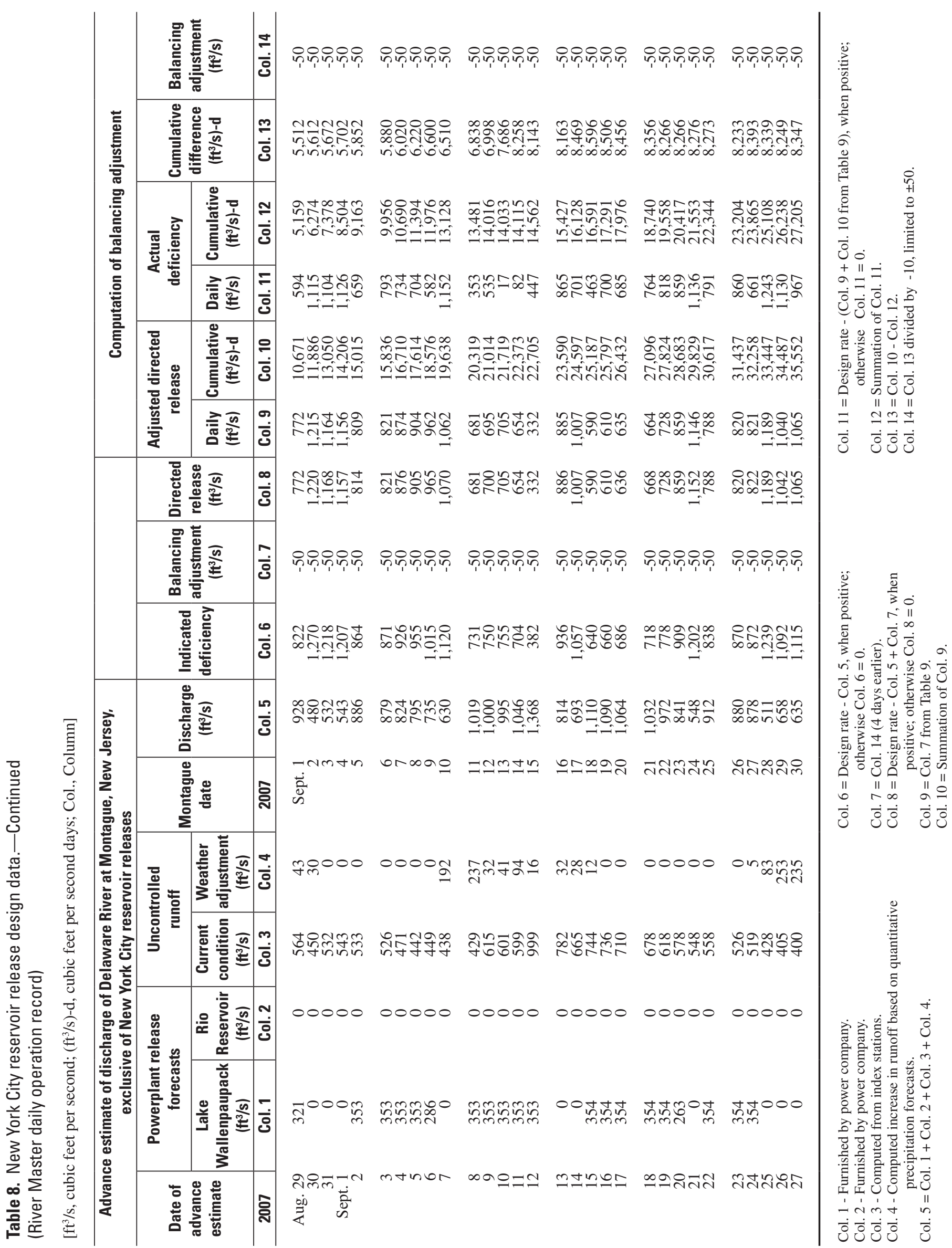




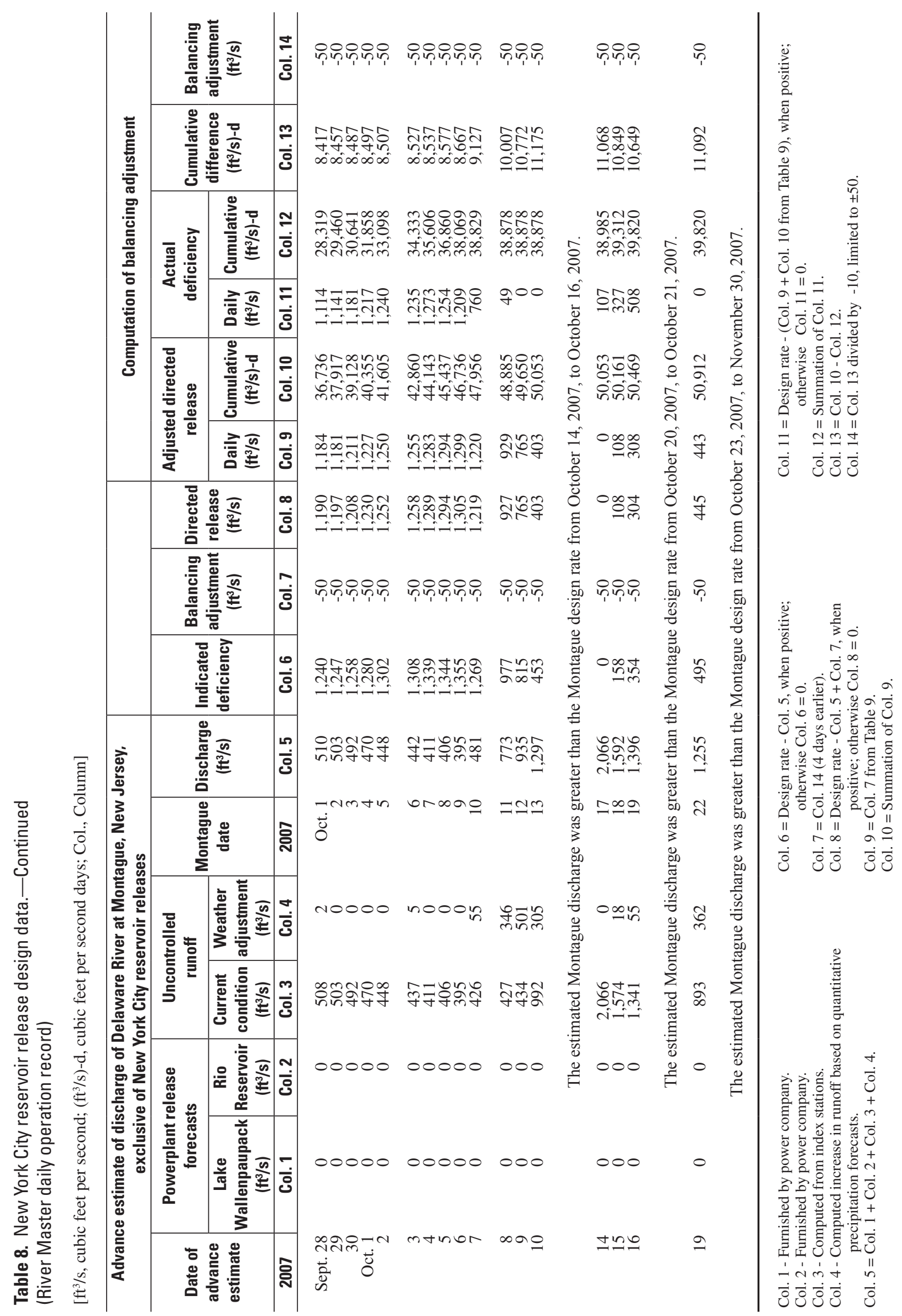




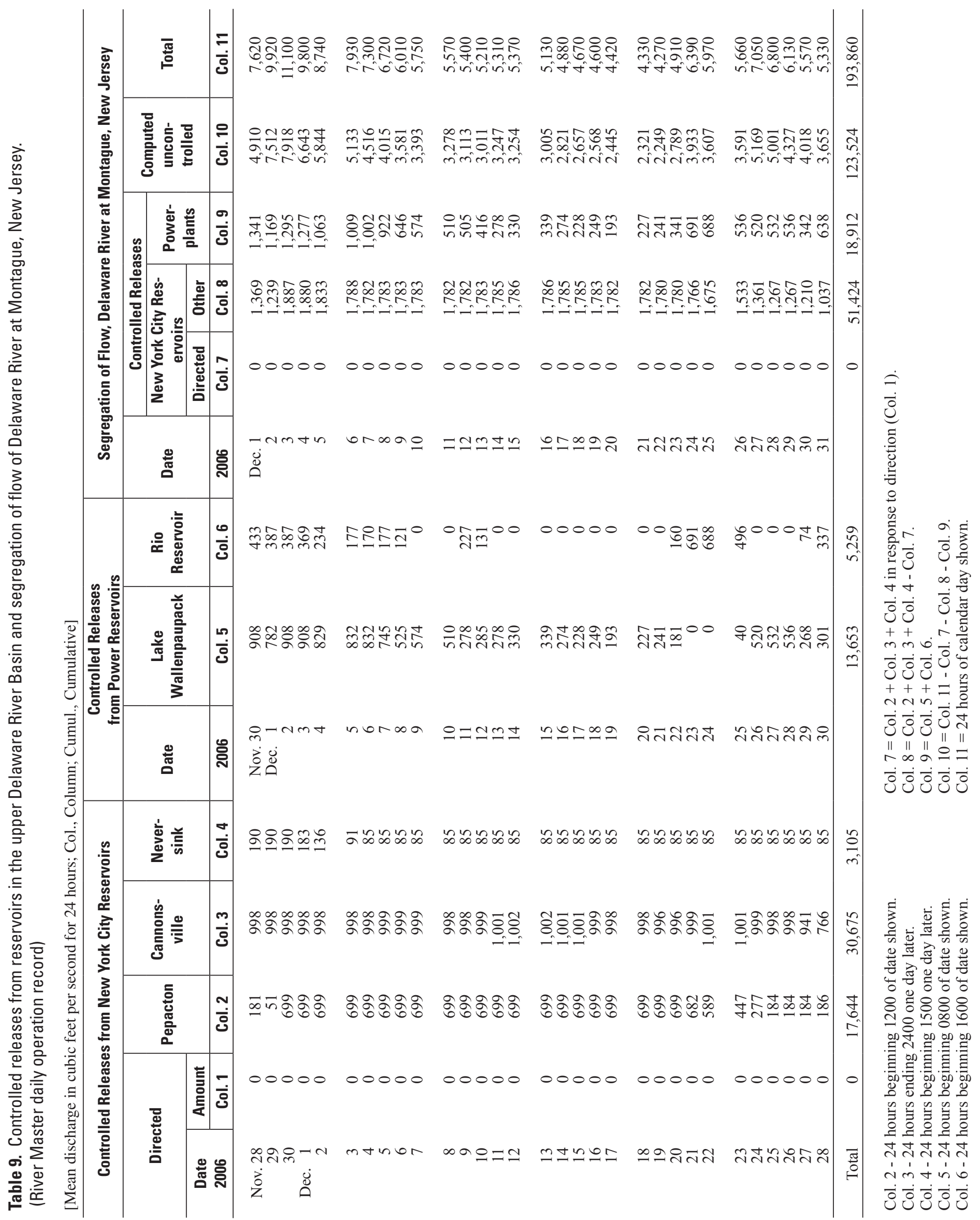




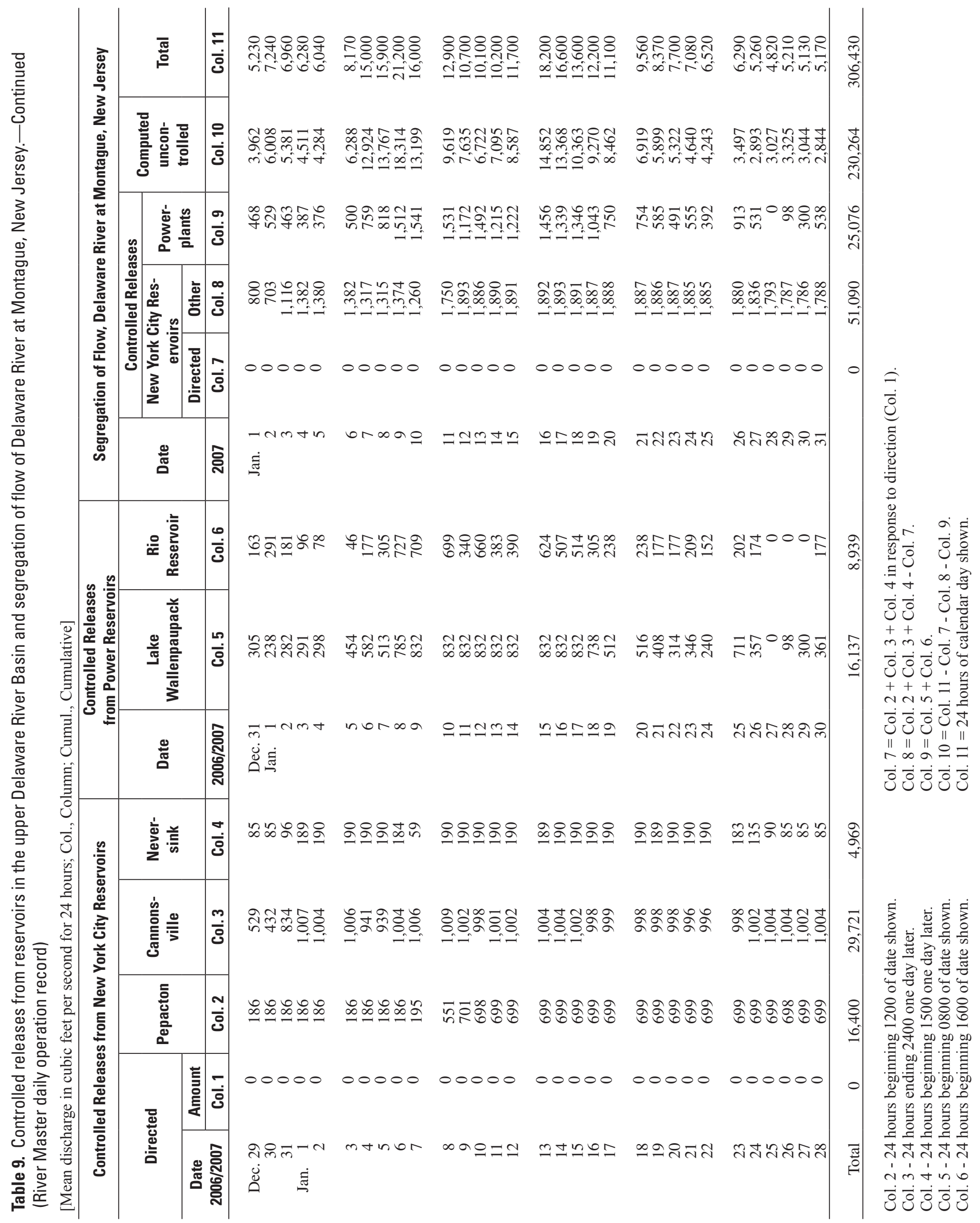




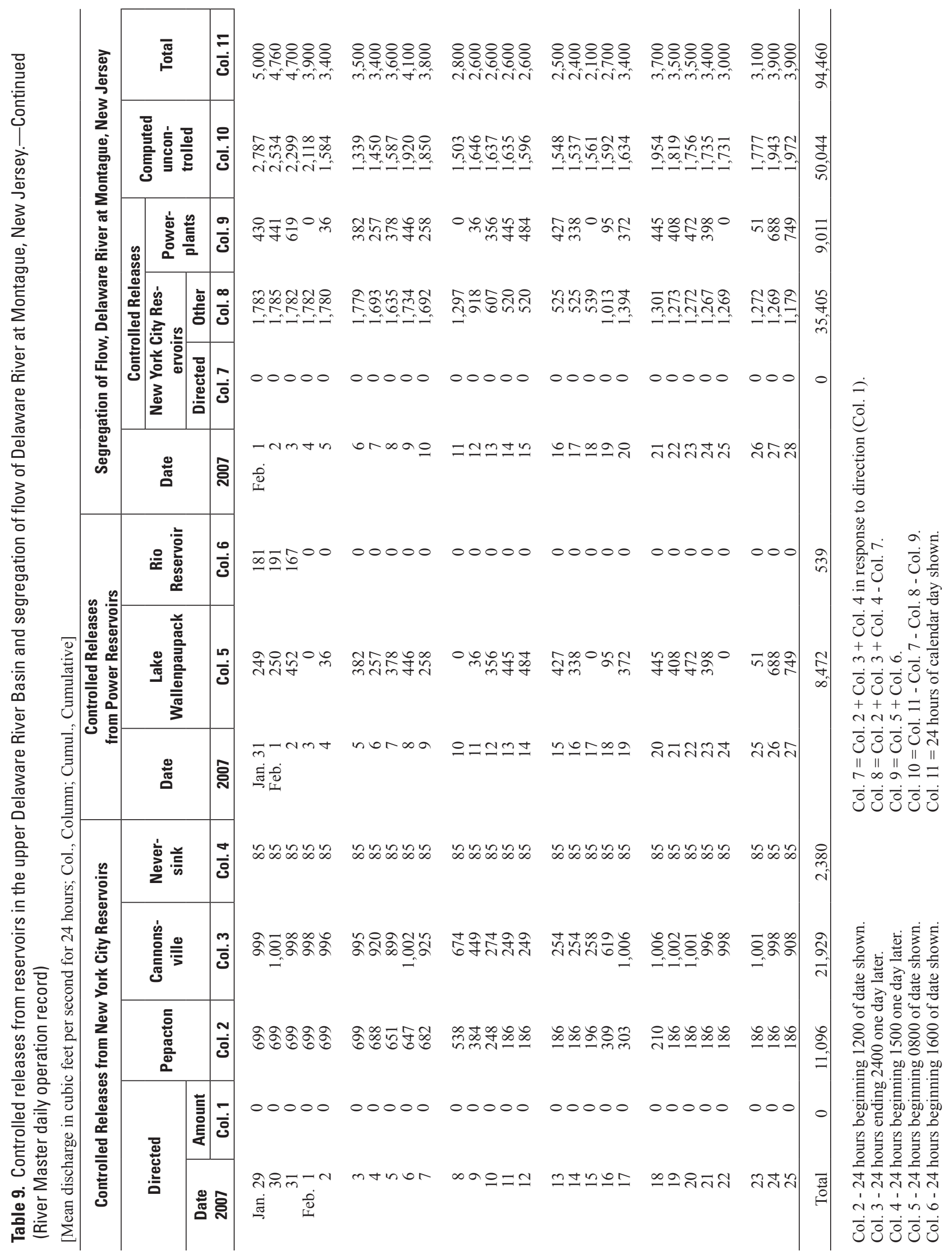




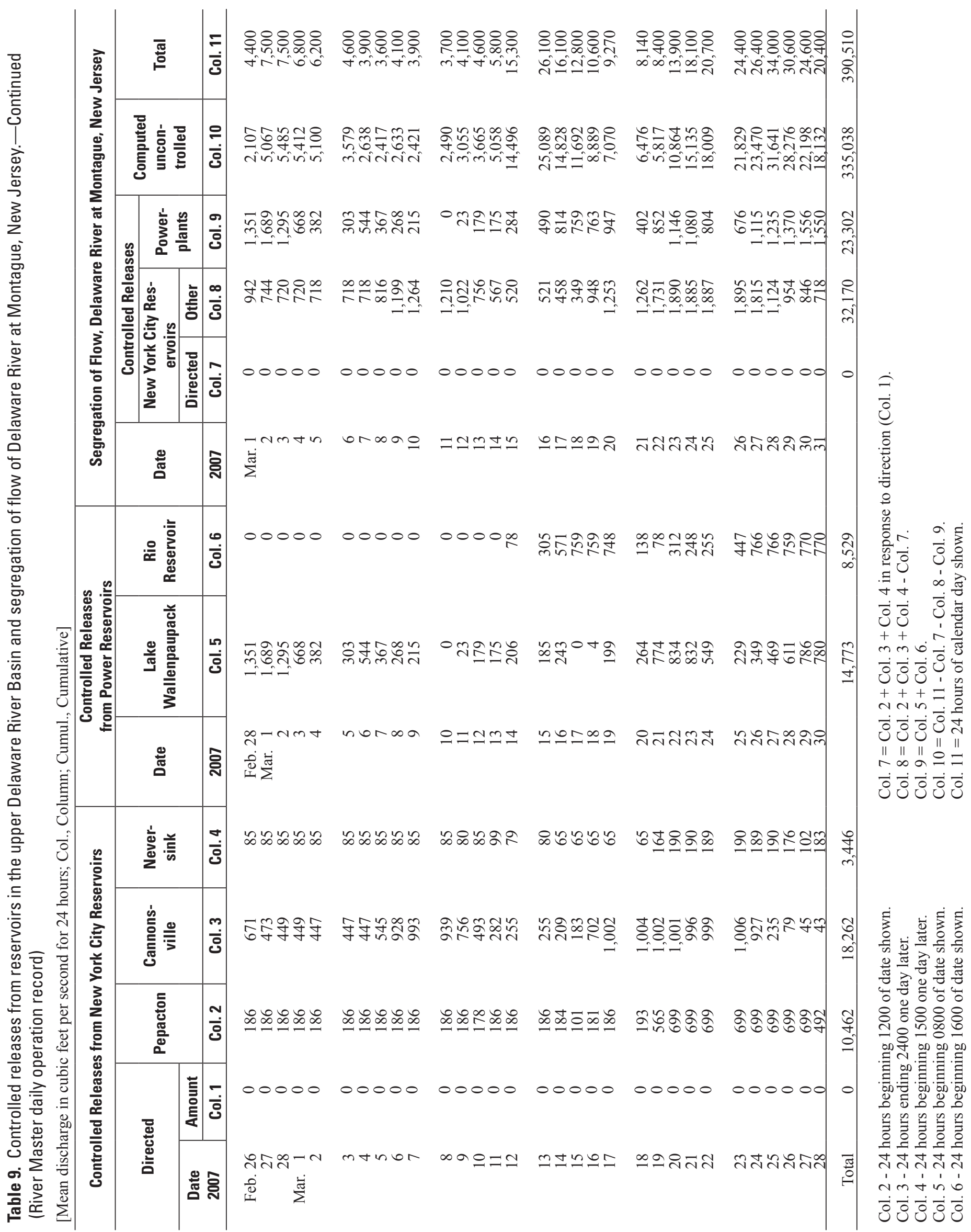




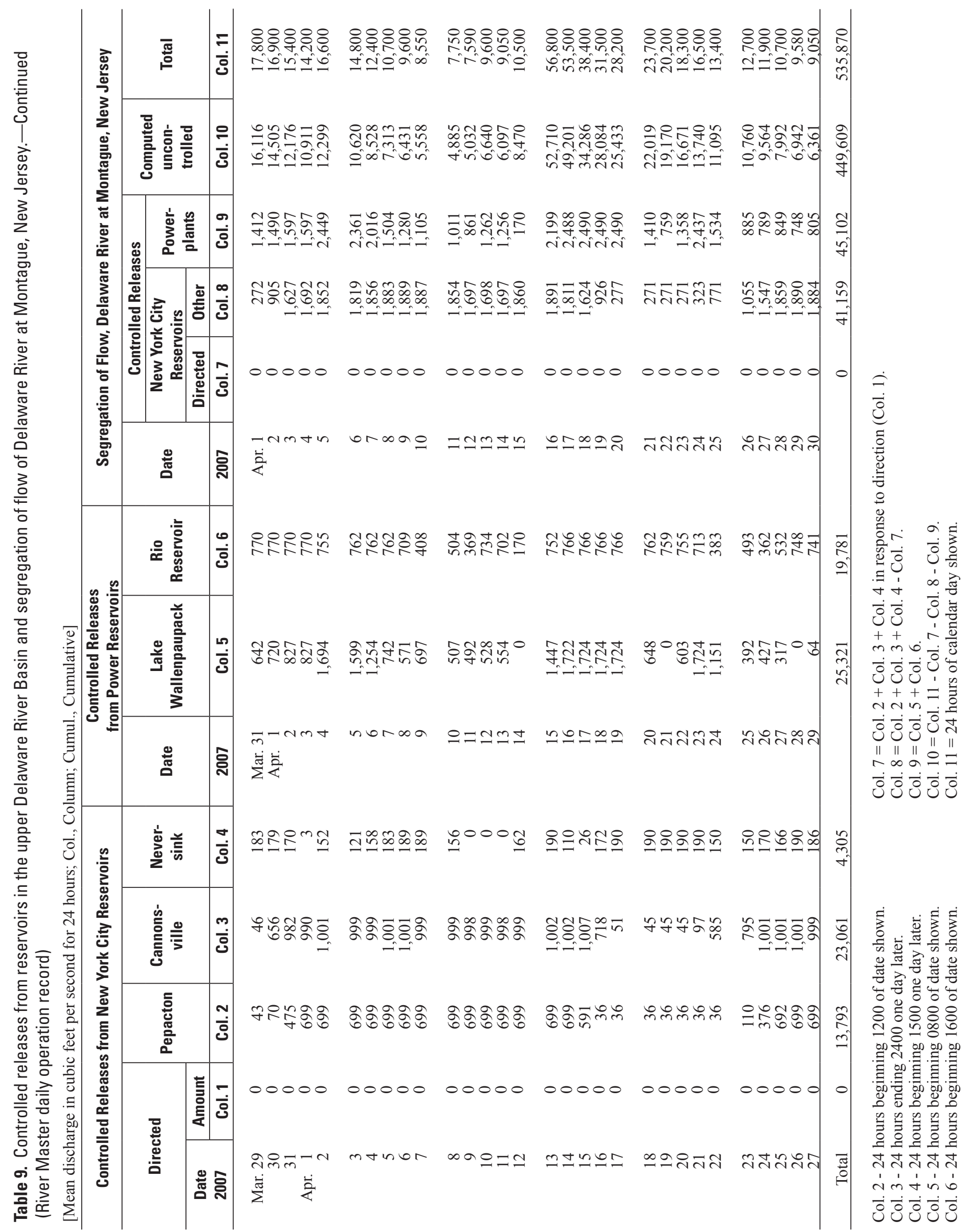




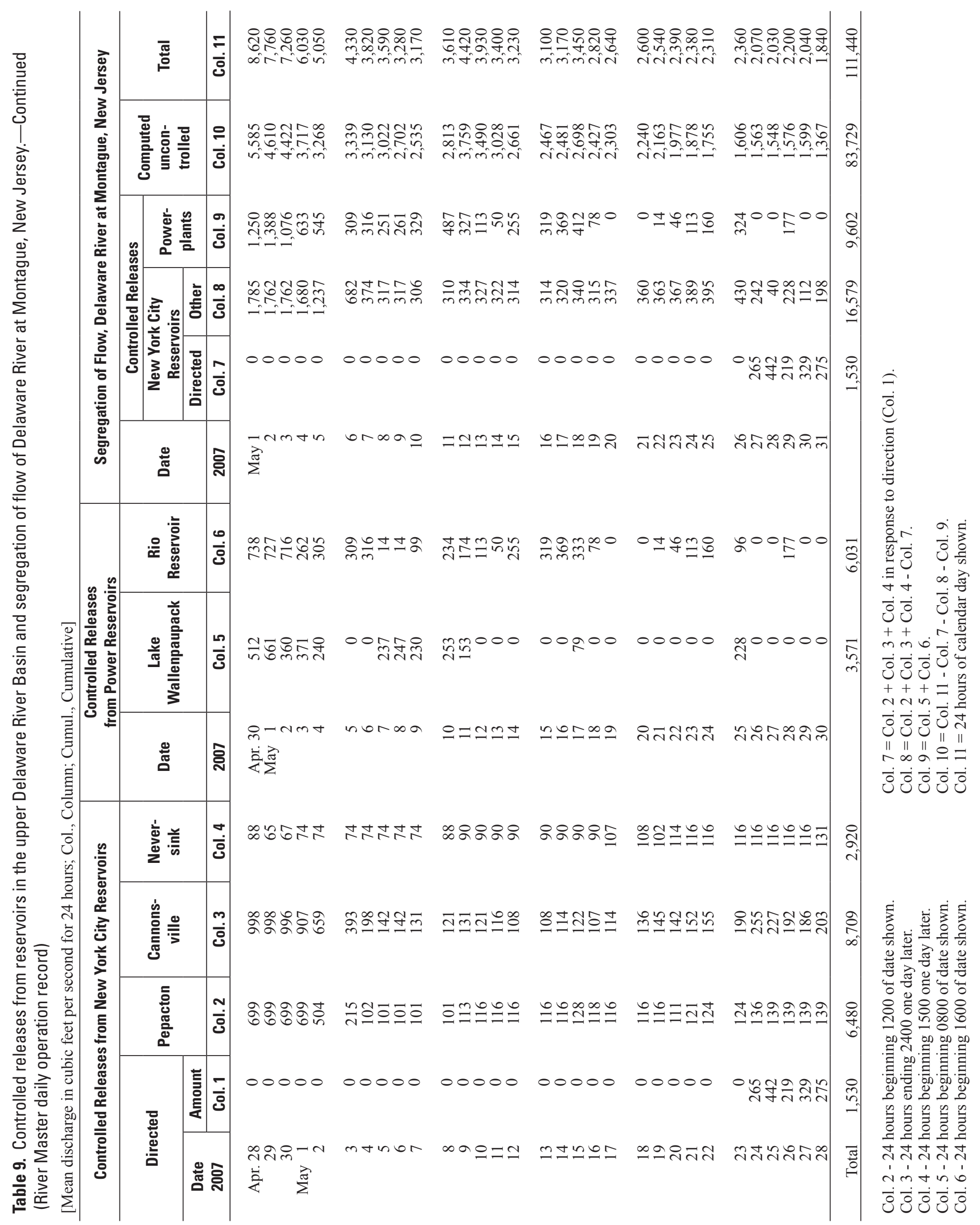




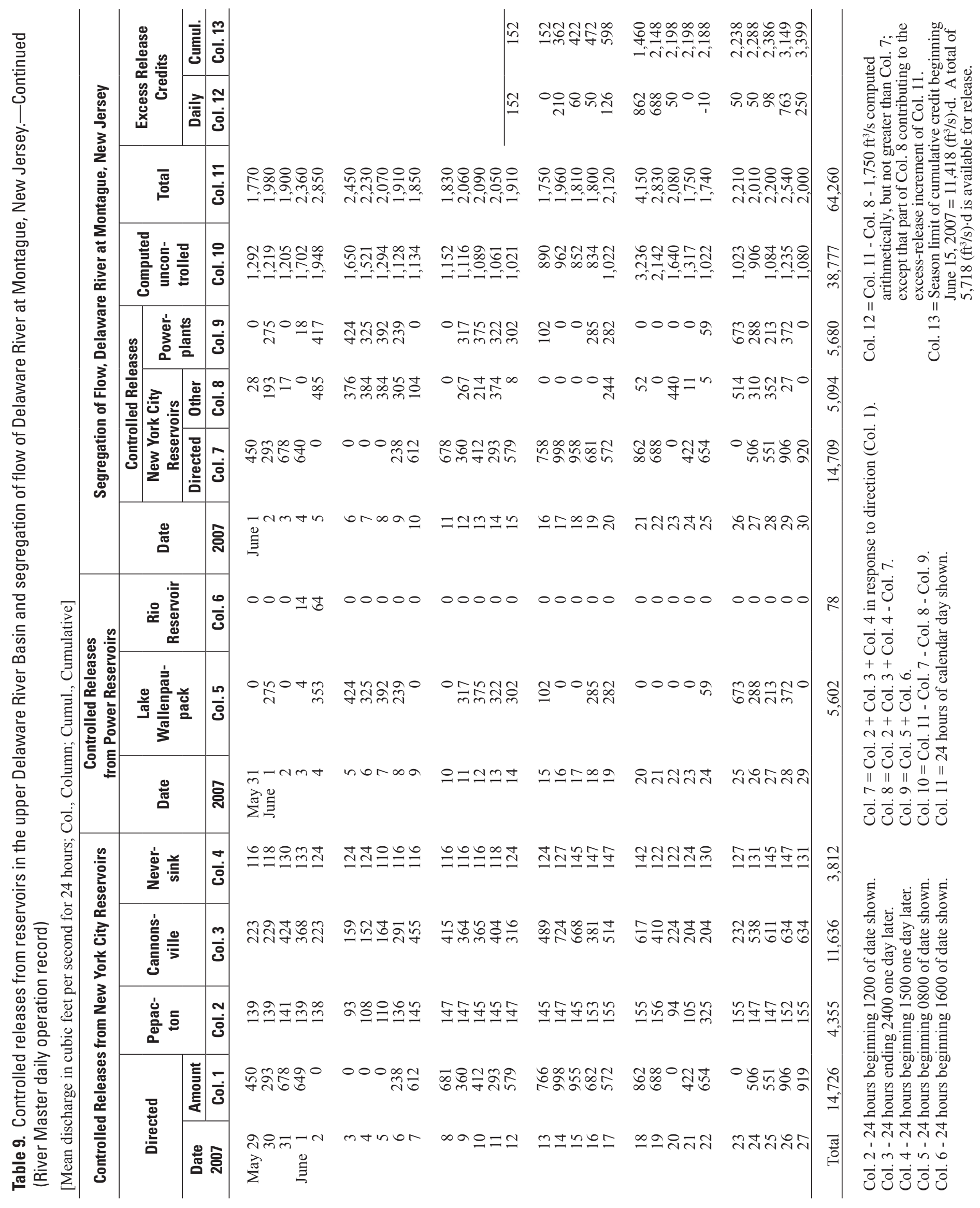




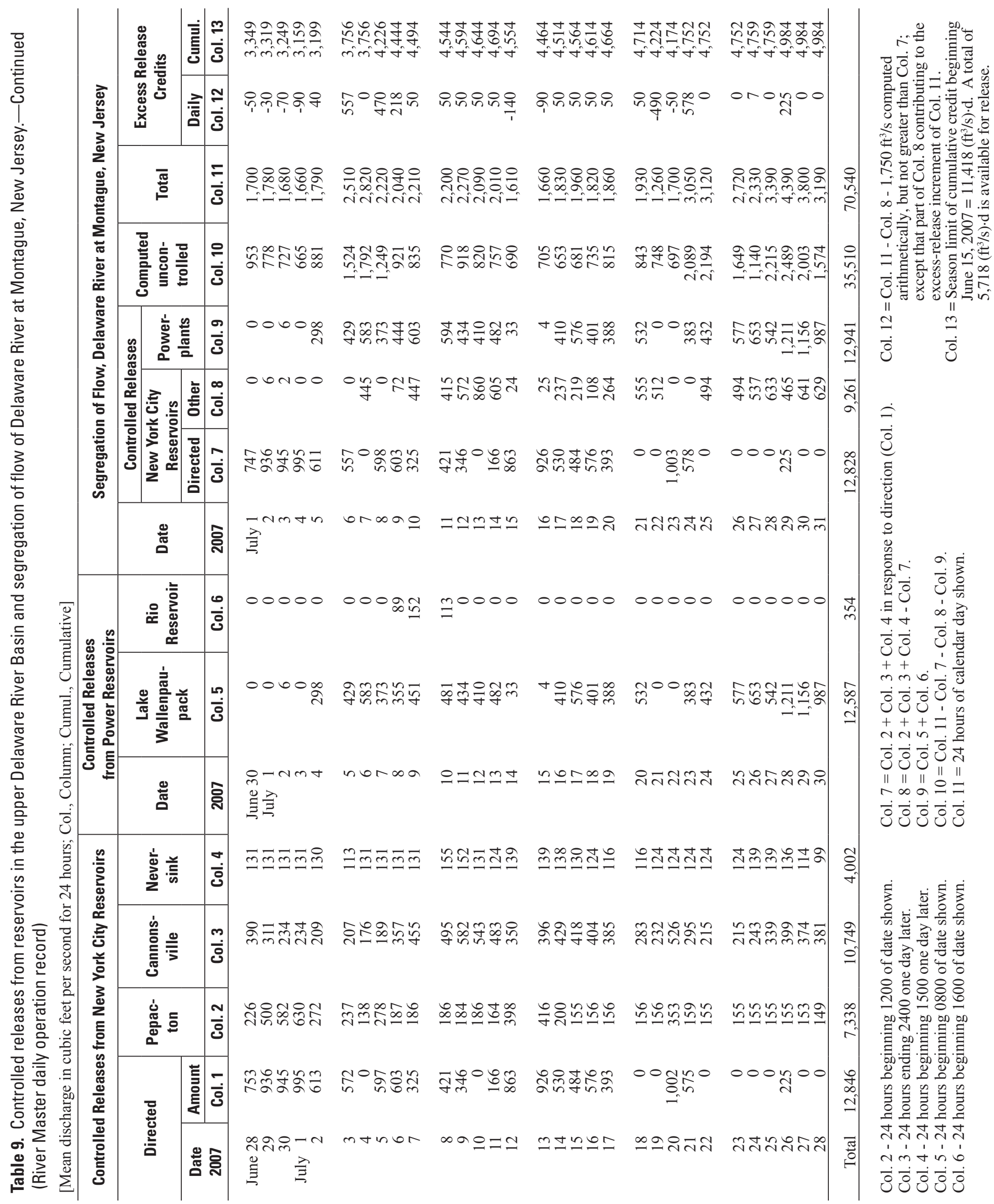




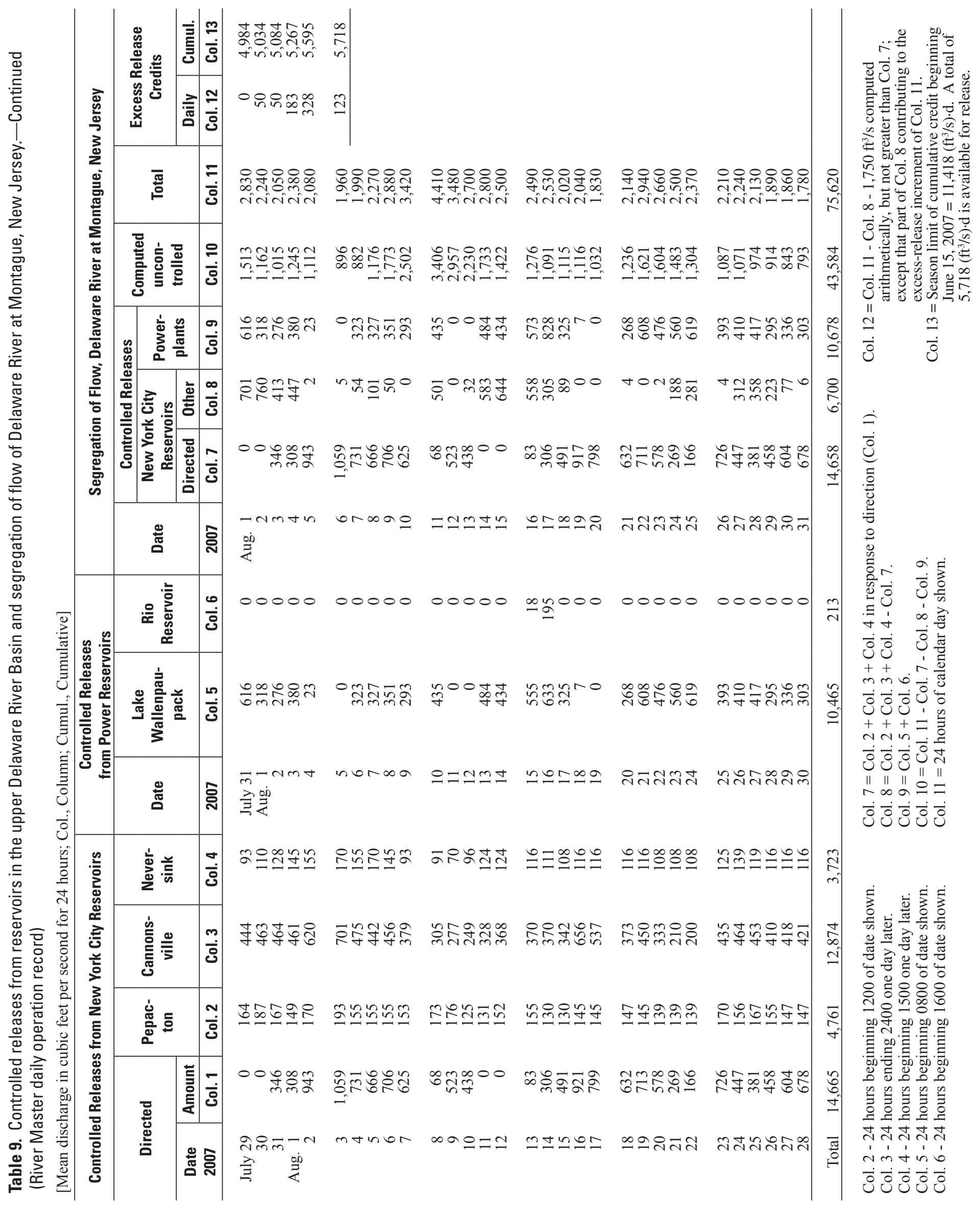




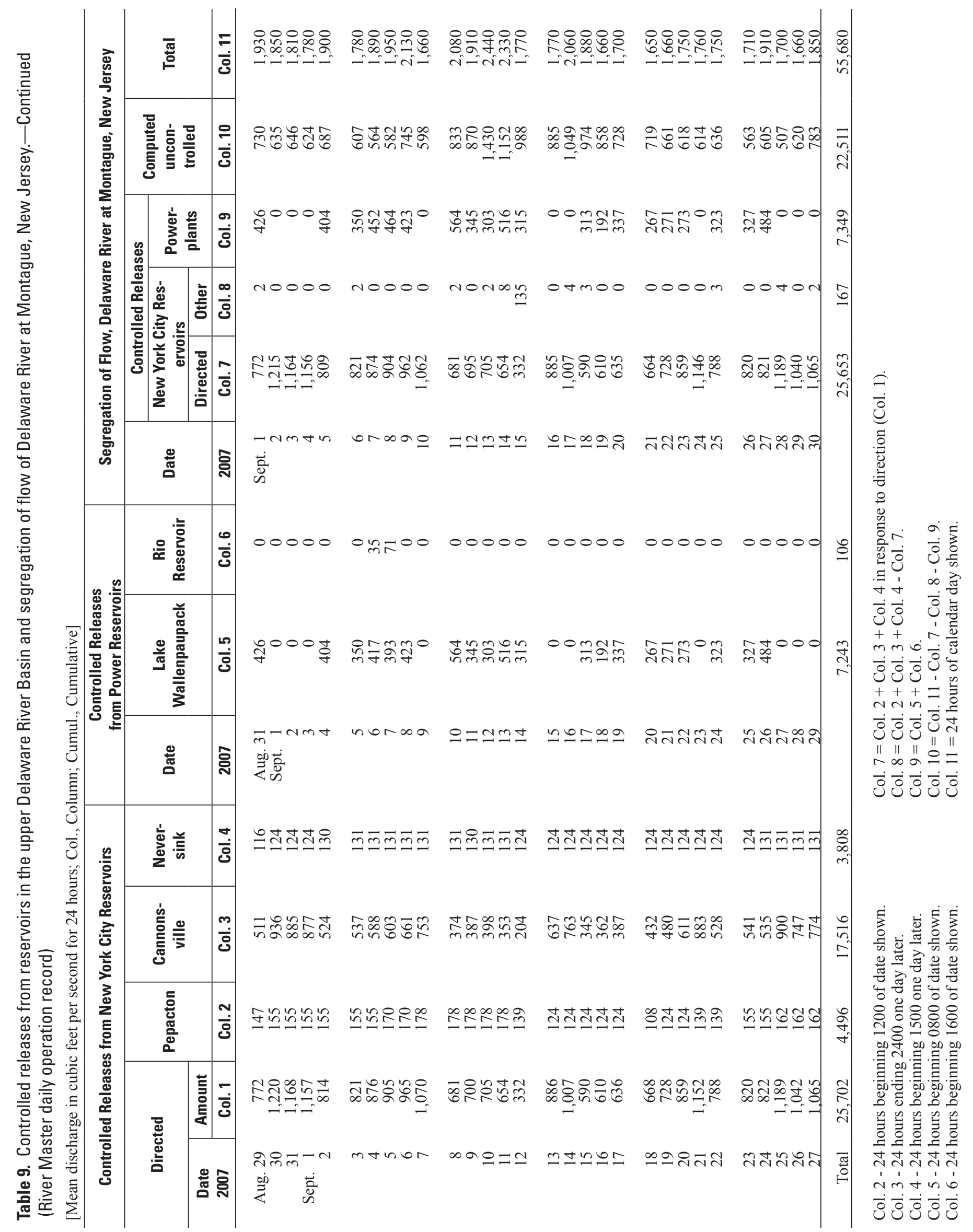




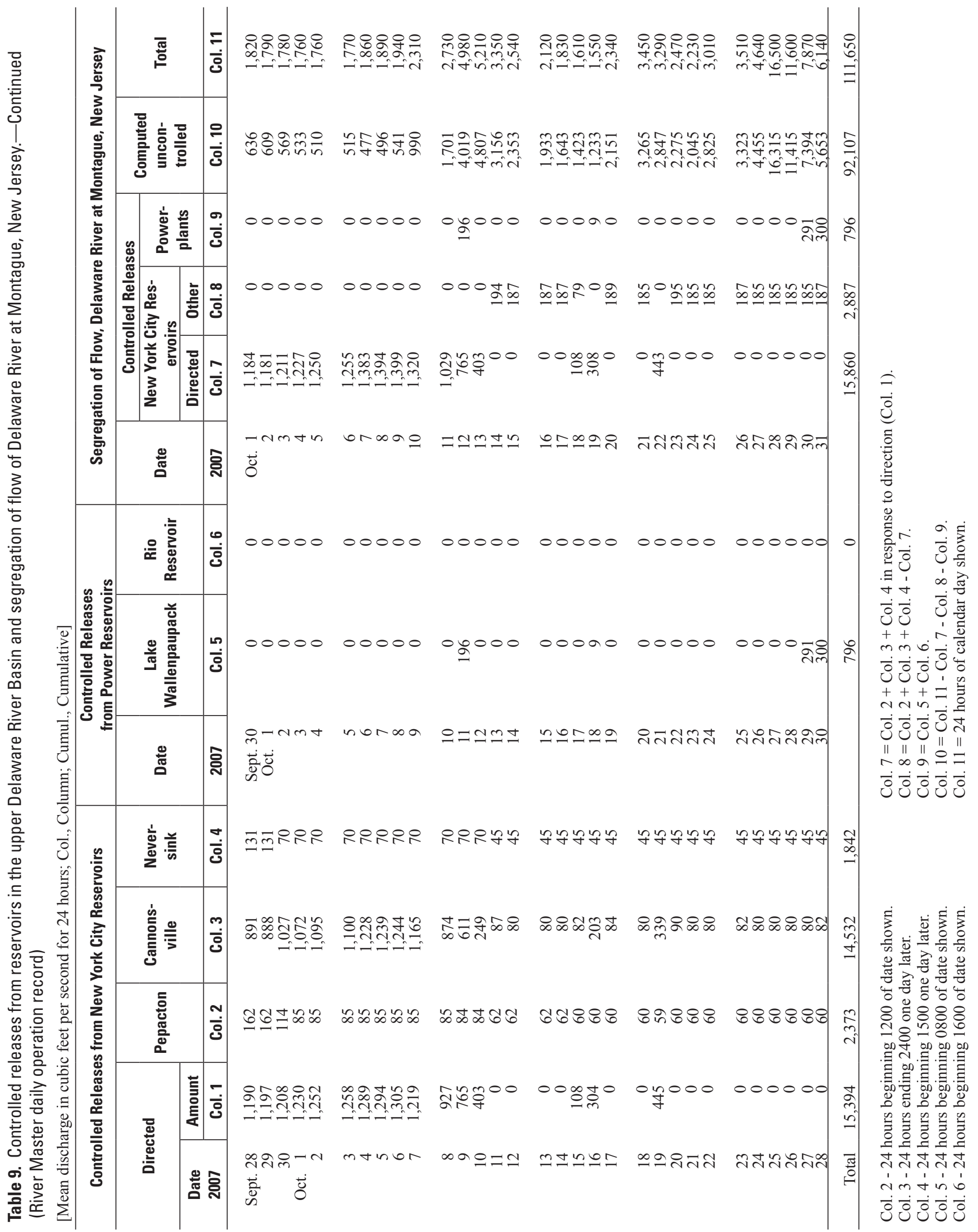




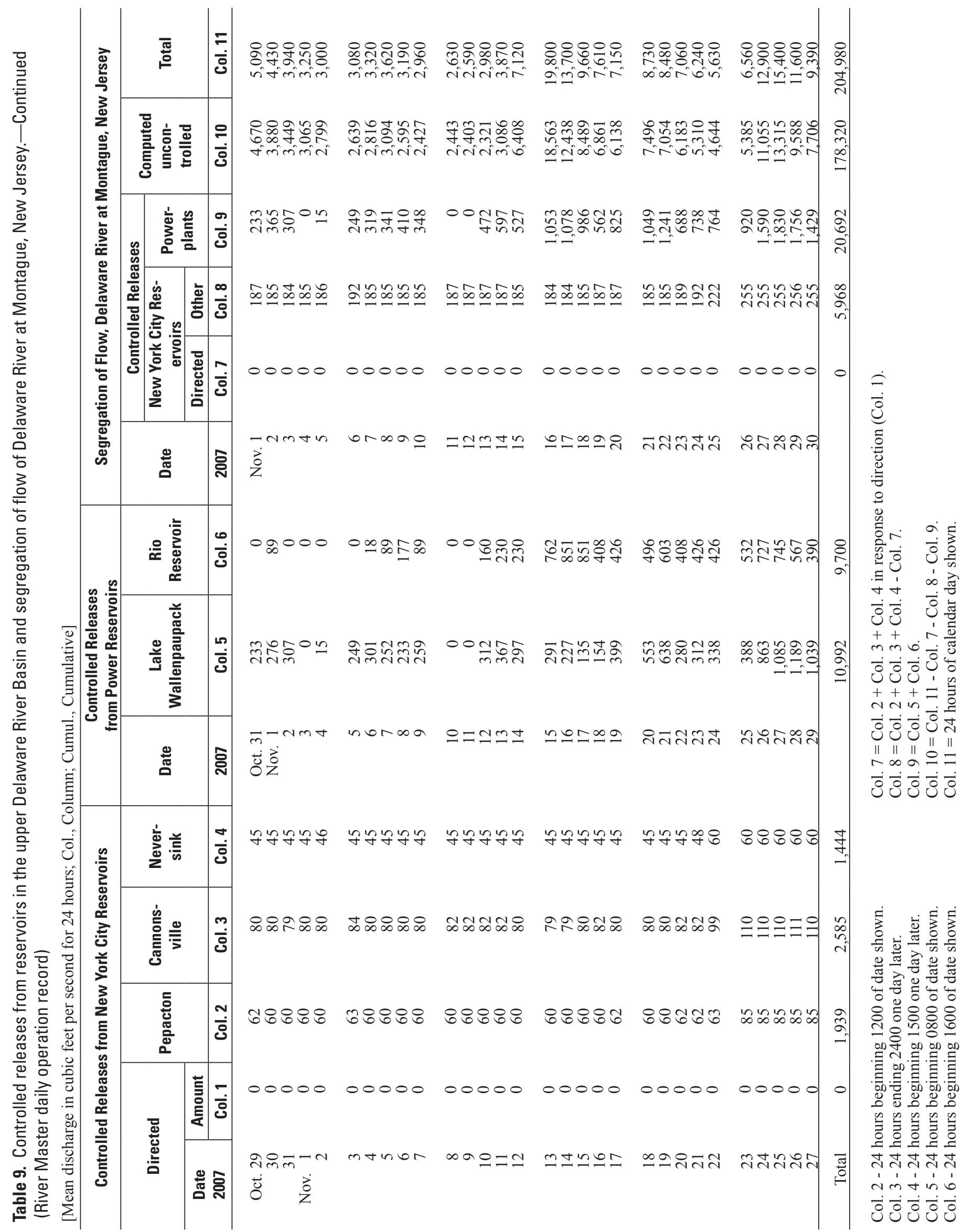




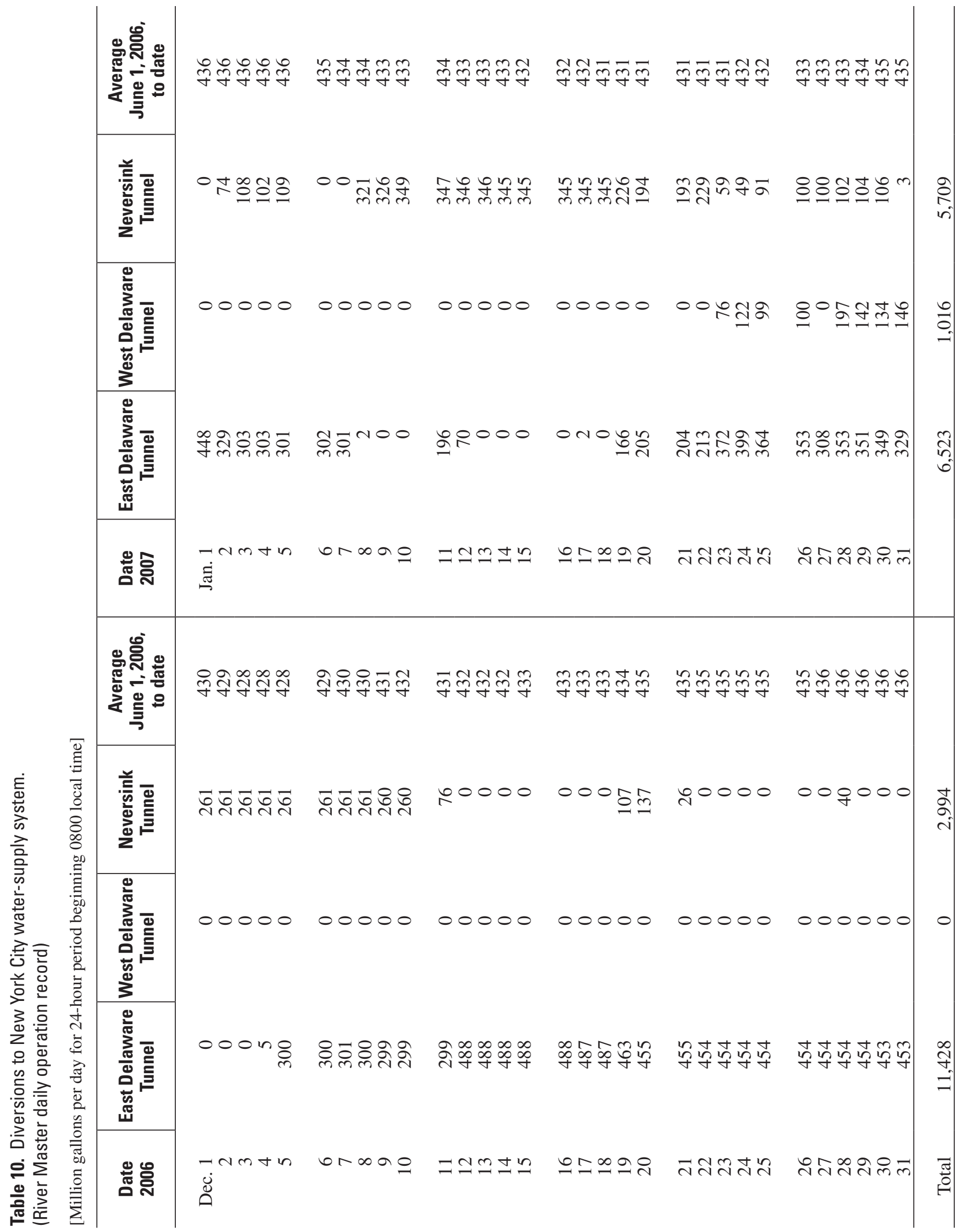




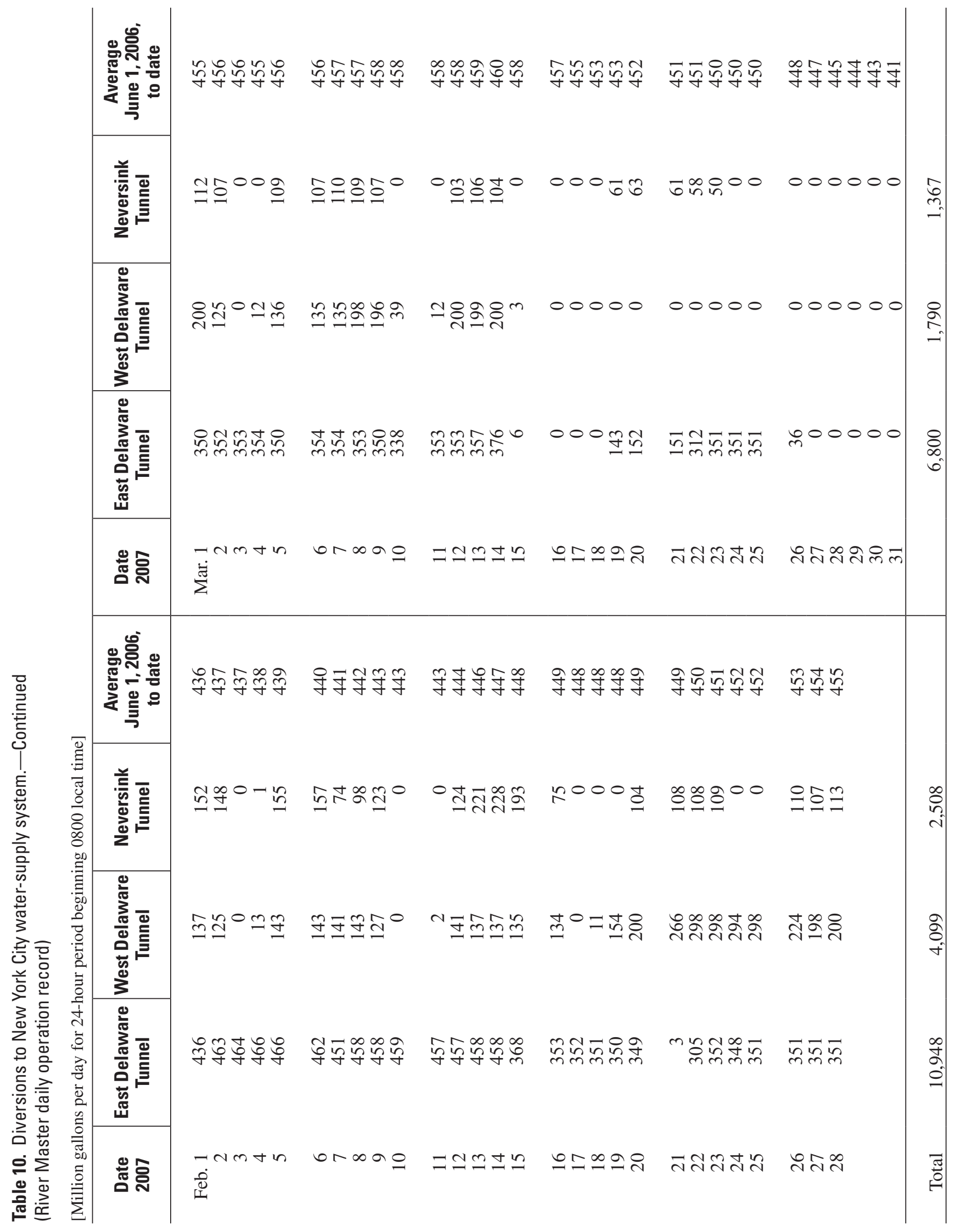




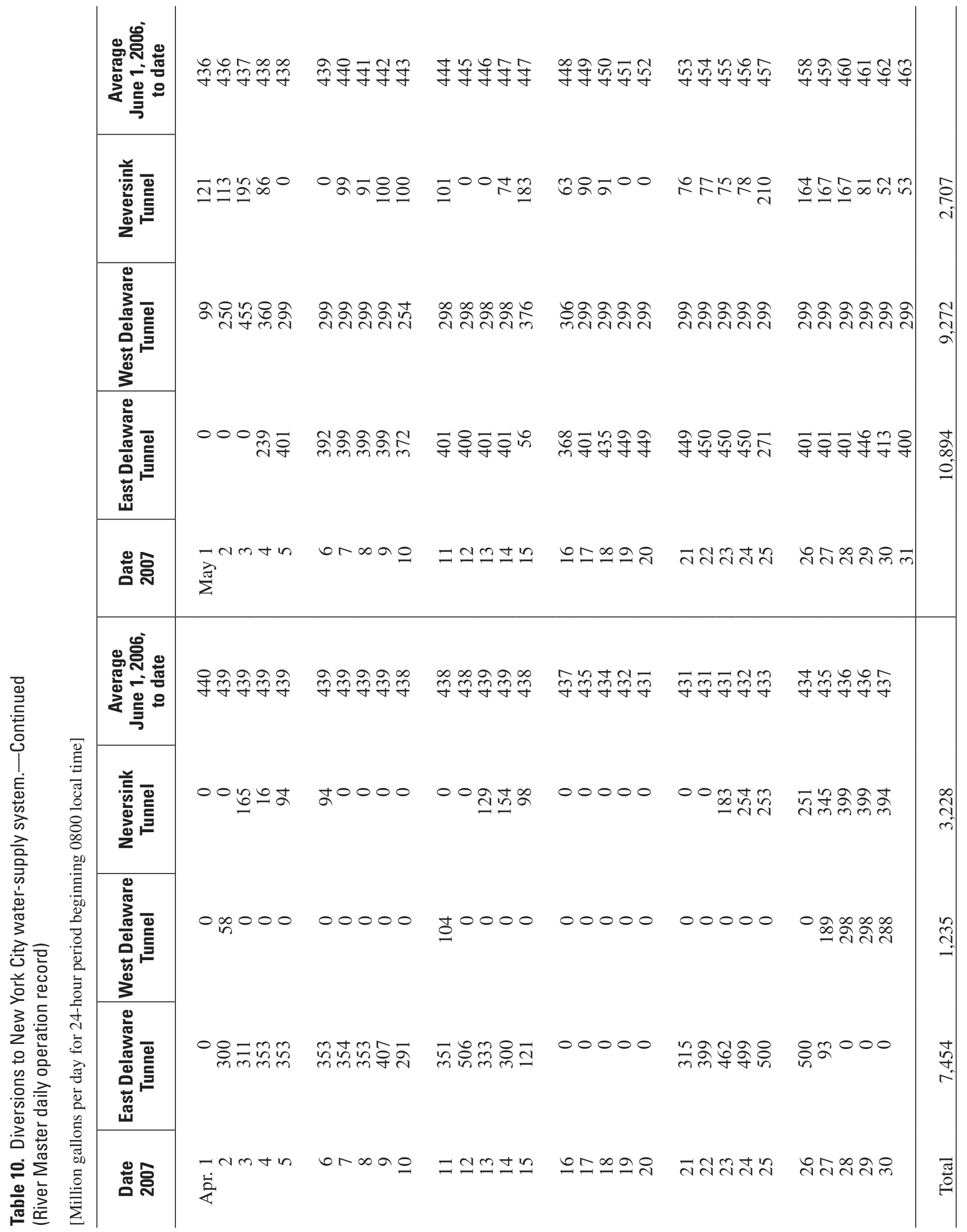




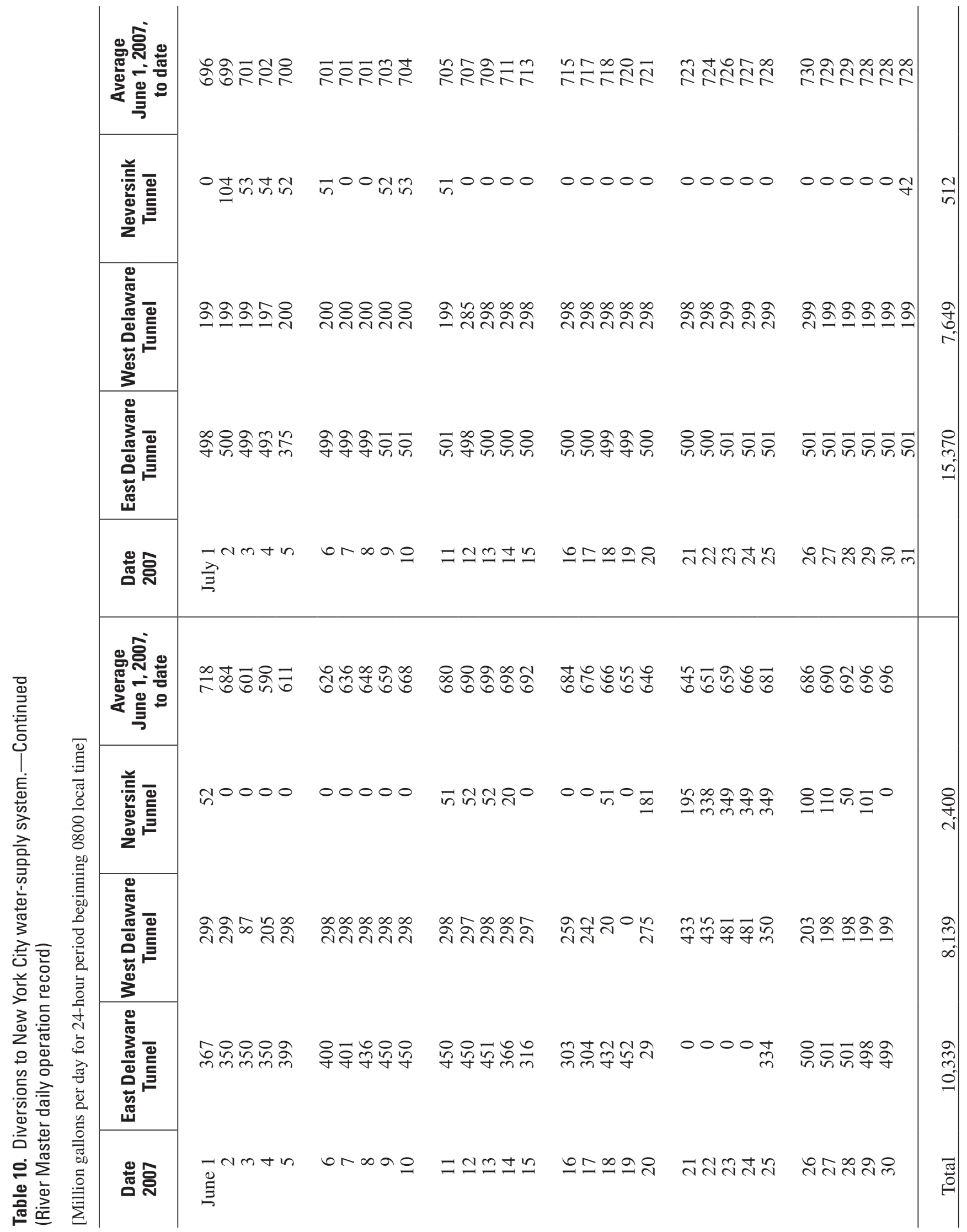




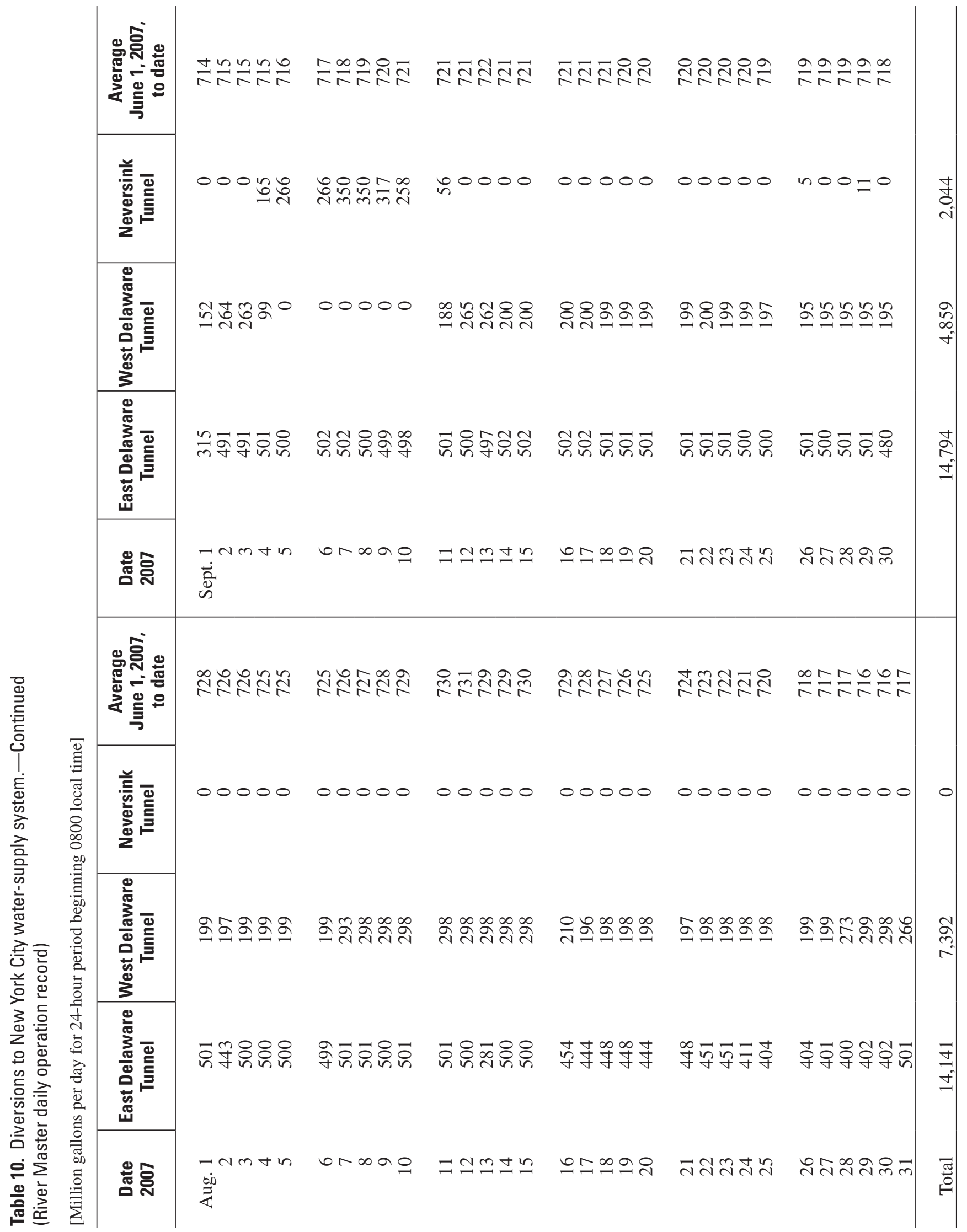




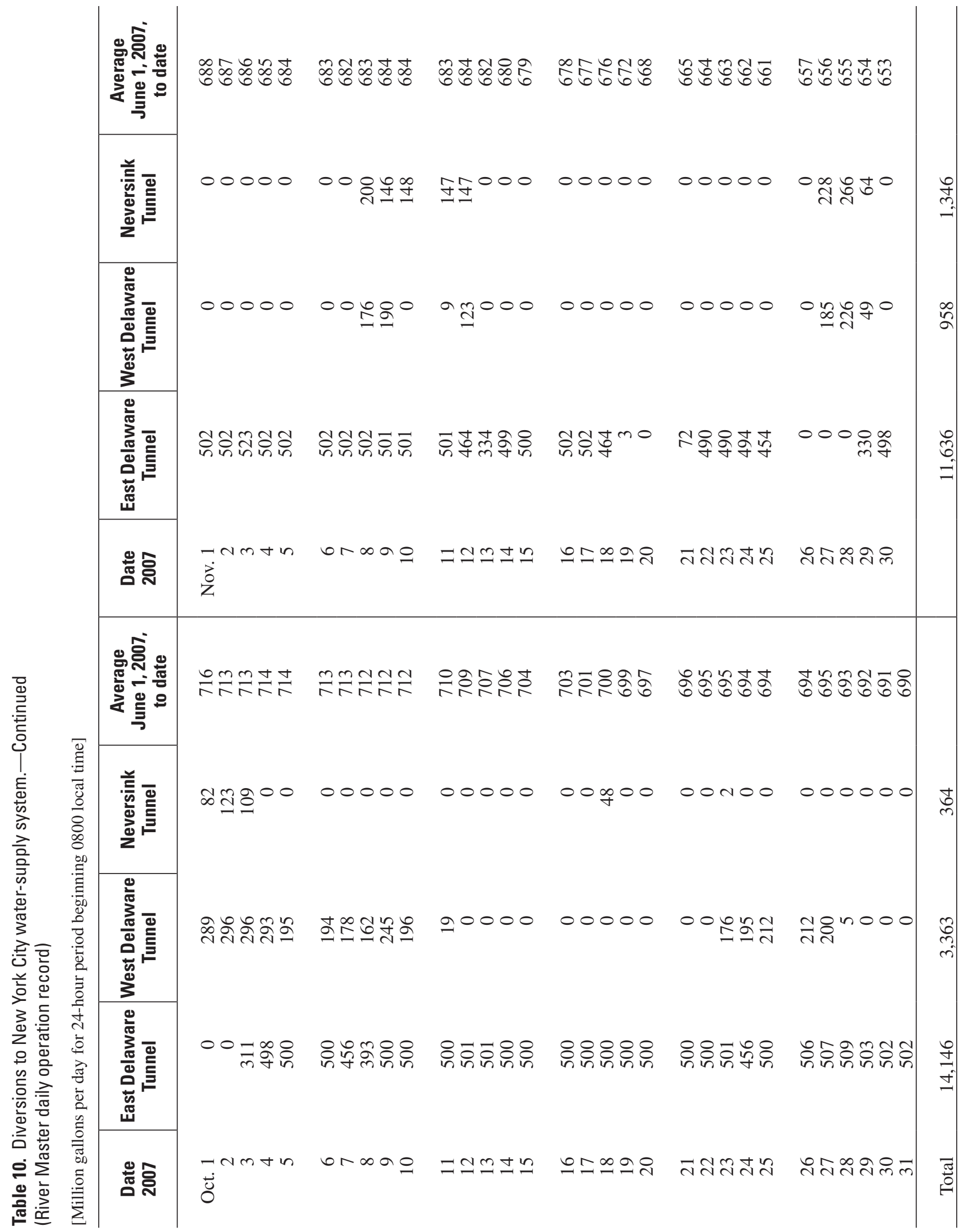




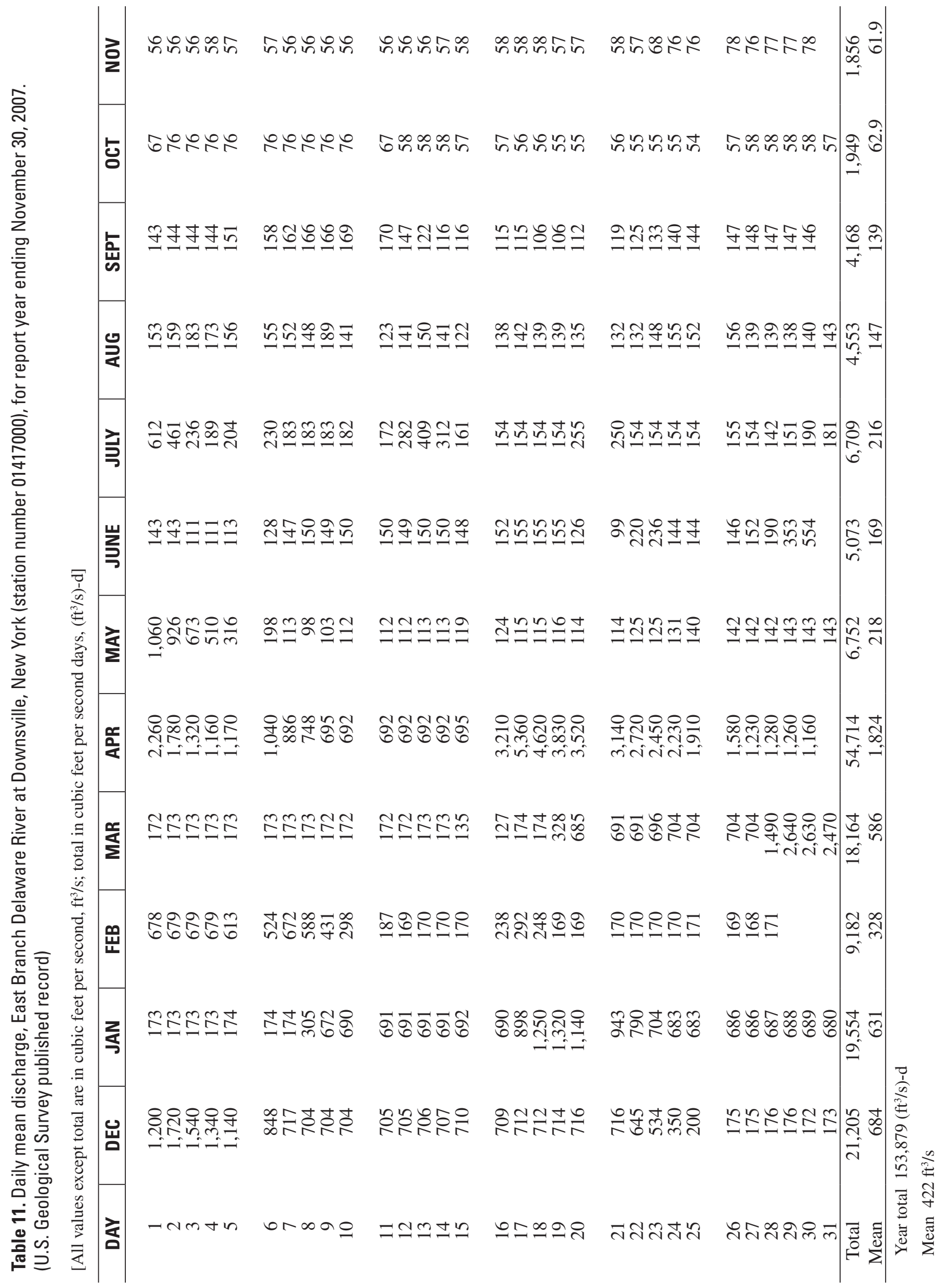




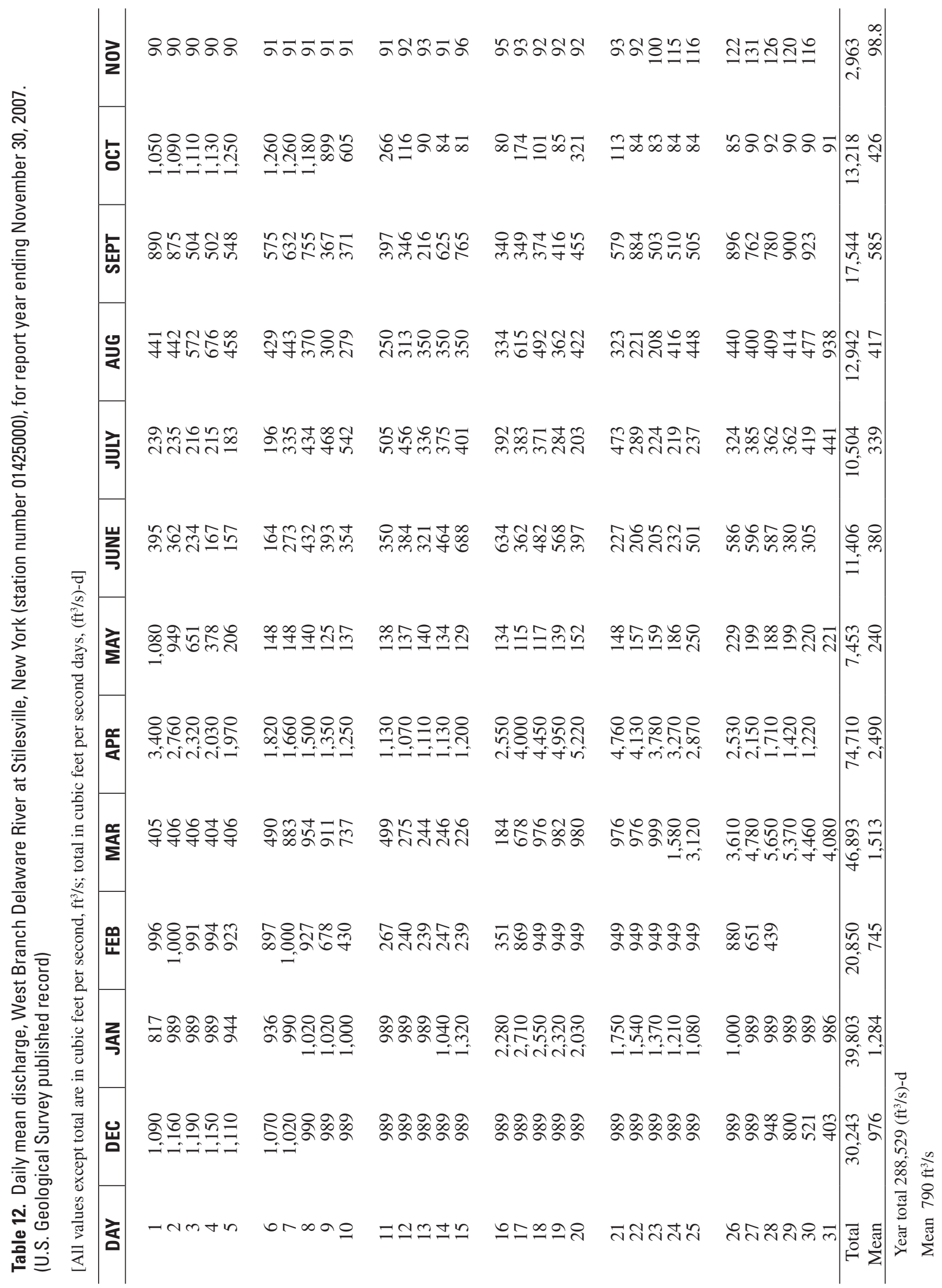




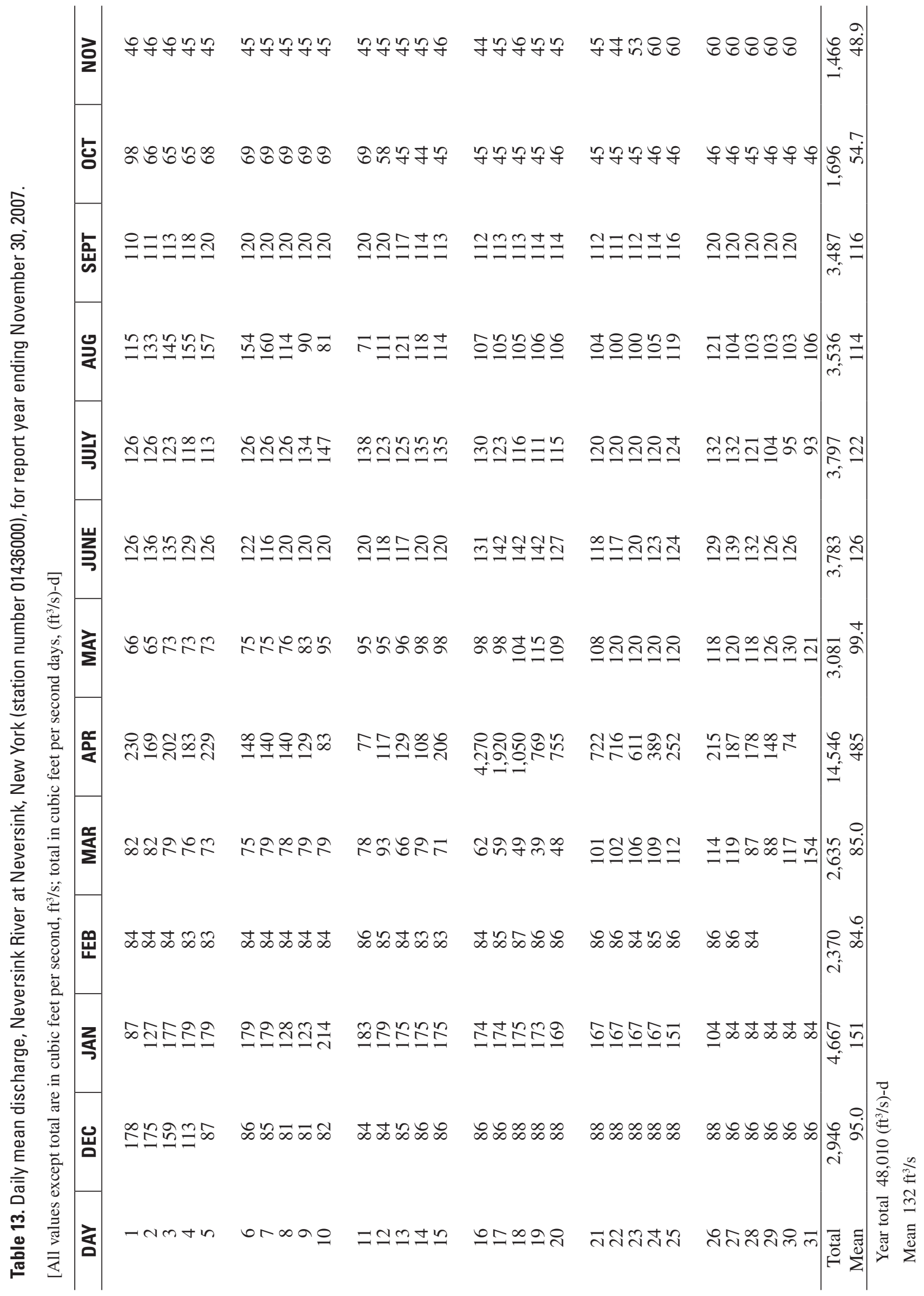




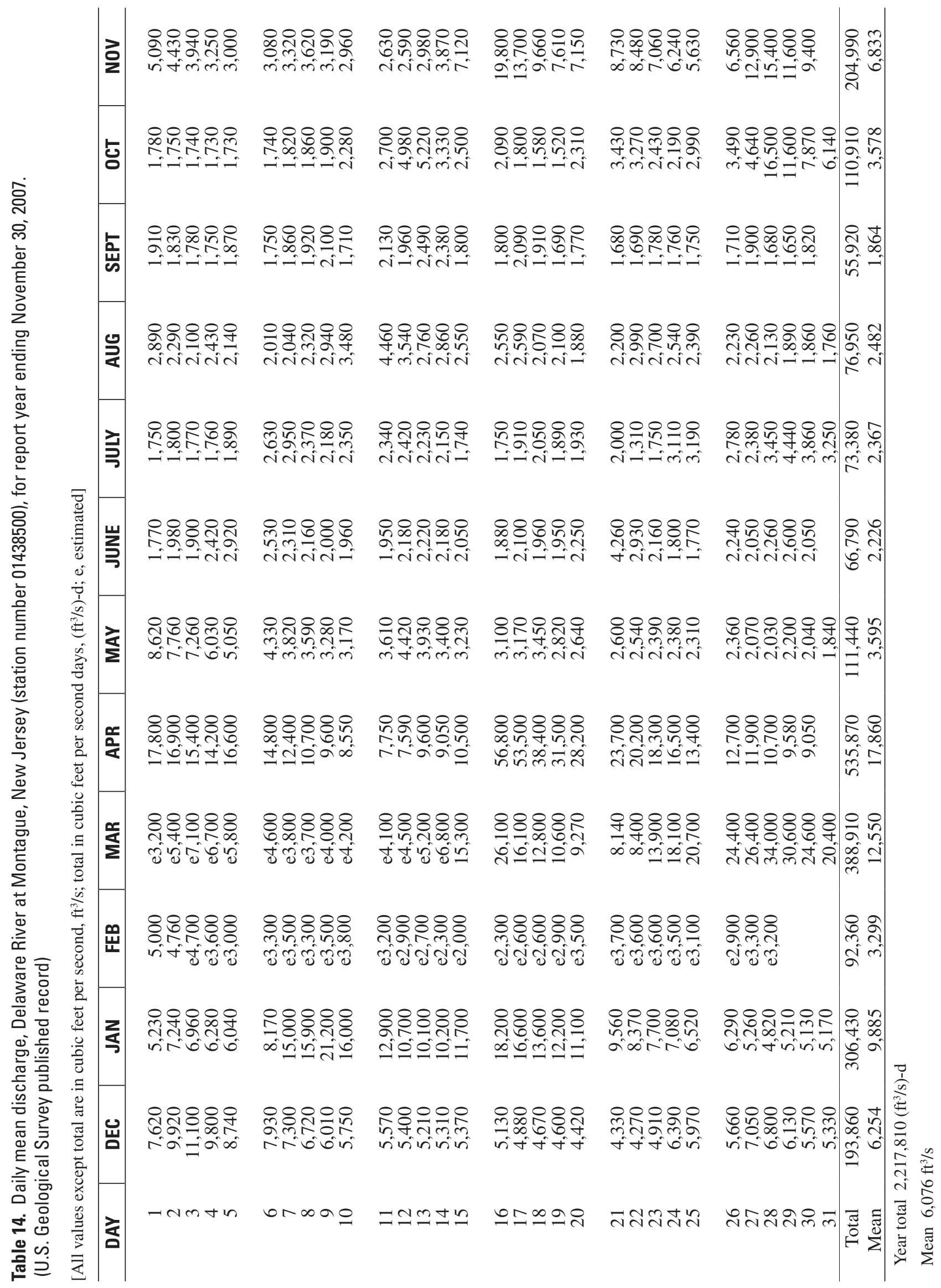




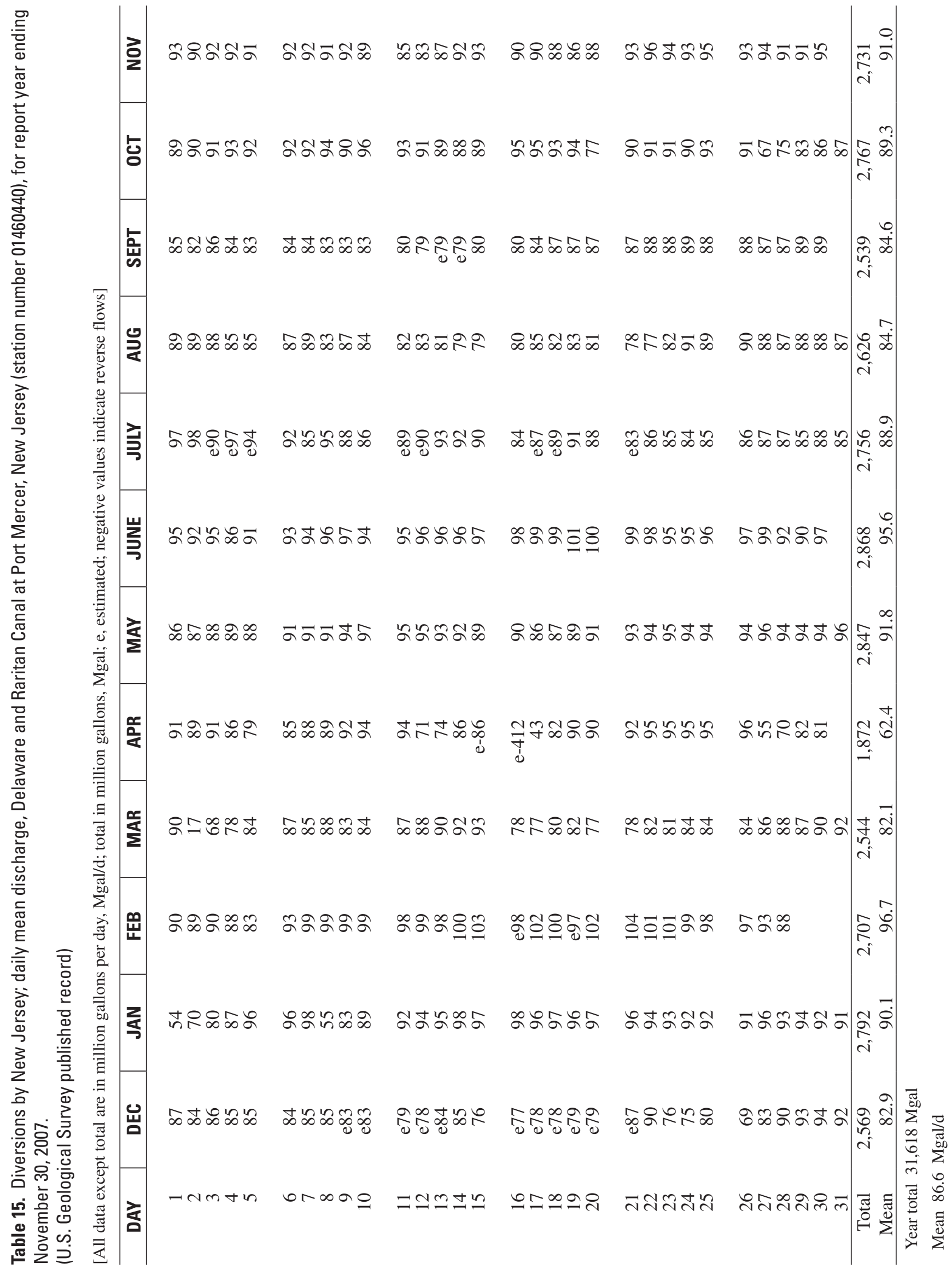




\section{QUALITY OF WATER IN THE DELAWARE ESTUARY}

\section{Introduction}

This section describes the water-quality monitoring program for the Delaware Estuary during the River Master 2007 report year, December 1, 2006, to November 30, 2007. This program is conducted by the USGS, in cooperation with the DRBC. Selected data collected for this program are presented and waterquality conditions are summarized. The DRBC and others use these data to assess water-quality conditions and track the movement of the "salt front" in the Delaware Estuary.

\section{Water-Quality Monitoring Program}

As part of a long-term program, the quality of water in the Delaware Estuary between Trenton, New Jersey, and Reedy Island Jetty, Delaware, is monitored at various locations (fig. 6). Data on water temperature, specific conductance, dissolved oxygen, and $\mathrm{pH}$ were collected by electronic instruments at four sites-Trenton, Benjamin Franklin Bridge (Philadelphia), Chester, and Reedy Island Jetty. Water-quality monitors at Trenton and Reedy Island Jetty were operated continuously throughout the report year and seasonally at the Benjamin Franklin Bridge and Chester.

The frequency of water-quality sampling was monthly in March, June, July, and October, and twicemonthly in April, May, August, and September 2007. Water samples at 19 sites between Biles Channel and Mahon River (sites A-T on fig. 6) were collected and analyzed by the State of Delaware for the DRBC. At each of these sites, water samples were collected near the center of the channel at a depth of 3 feet below the water surface and analyzed for selected physical properties and chemical constituents including, but not limited to, water temperature, chloride, alkalinity, specific conductance, dissolved oxygen, $\mathrm{pH}$, selected nutrients, and trace metals. These analyses consist of field measurements and laboratory determinations.

From March to October, but excluding June, water-quality samples were collected on a monthly basis at three additional sites in the lower Delaware Bay (sites U-W on fig. 6) and analyzed for selected physical properties and chemical constituents.

Data obtained from the electronic water-quality monitors are processed and stored in the USGS National Water Information System database. These data are posted online by the USGS in annual water resources data reports for New Jersey and Pennsylvania. Water-quality data for the other sampling sites are not presented in this report but are available from DRBC and STORET, an environmental quality database operated by the U.S. Environmental Protection Agency. 


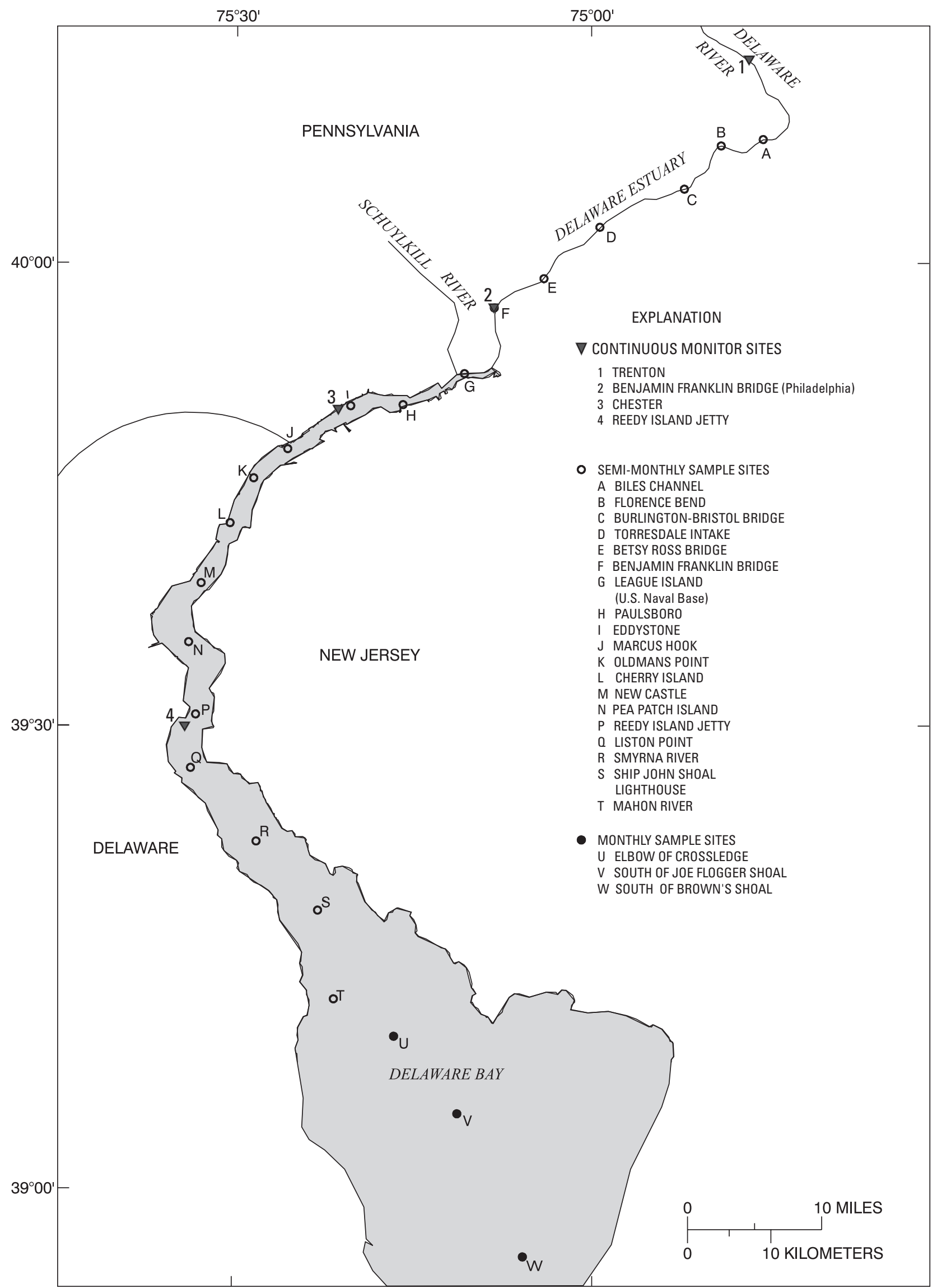

Figure 6. Location of water-quality monitoring sites on the Delaware Estuary. 


\section{Water Quality During the 2007 Report Year}

\section{Streamflow}

Streamflow has a major effect on the quality of water in the Delaware Estuary. High freshwater inflows commonly result in improved water quality by limiting the upstream movement of seawater and reducing the concentration of dissolved substances. High inflows also aid in maintaining lower water temperatures during warm weather and in supporting higher concentrations of dissolved oxygen. Under certain conditions, however, high streamflows can transport large quantities of nutrients to the estuary, which may result in excessive levels of algae.

Streamflow from the Delaware River Basin upstream of Trenton, New Jersey, is the major source of freshwater inflow to the Delaware Estuary. During the report year, monthly mean streamflow measured at the USGS gaging station Delaware River at Trenton, New Jersey, was highest during April 2007 $\left(35,000 \mathrm{ft}^{3} / \mathrm{s}\right)$ and lowest during September 2007 (3,862 ft $3 / \mathrm{s}$; table 16 $\left.{ }^{3}\right)$. Monthly mean streamflows were less than long-term mean monthly flows in February, May, June, July, and September 2007, and greater than the long-term flows in the other seven months. The greatest flow deficiency was in February 2007, when monthly mean streamflow was 54 percent of the long-term mean monthly flow. Long-term monthly mean streamflow was computed on the basis of data for the period from 1913 to 2006. The highest daily mean streamflow during the report year was $111,000 \mathrm{ft}^{3} / \mathrm{s}$ on April 17, 2007. The lowest daily mean streamflow was 3,000 $\mathrm{ft}^{3} / \mathrm{s}$ on October 8, 2007.

\section{Water Temperature}

Water temperature has an important influence on water quality, as it affects various physical, chemical, and biological properties of water. Generally, increases in water temperature have detrimental effects on water quality by decreasing the saturation level of dissolved oxygen and increasing the biological activity of aquatic organisms. Although the primary factors that affect water temperature in the Delaware Estuary are climatic, various kinds of water use, especially powerplant cooling, also can have significant effects.

At the Benjamin Franklin Bridge, Philadelphia, Pennsylvania, water-temperature data were collected continuously from April to November 2007. Monthly mean temperatures were greater than the long-term mean monthly temperatures in May, June, August, September, and October 2007, and were less than the long-term means in April, July, and November 2007. Long-term mean water temperatures were computed using data for the period from 1964 to 2006 (fig. 7). The maximum daily mean water temperature of 28. $3^{\circ} \mathrm{C}$ was recorded on August 9, 2007.

\section{Specific Conductance and Chloride}

Specific conductance is a measure of the capacity of water to conduct an electrical current and is a function of the types and quantities of dissolved substances in water. As concentrations of dissolved ions increase, specific conductance of the water also increases. Specific conductance measurements are good indicators of dissolved solids content and total ion concentrations. Seawater and some man-made constituents can cause the specific conductance of estuary water to increase substantially. Dilution associated

\footnotetext{
${ }^{3}$ All numbered tables in the section "Quality of Water in the Delaware Estuary" are grouped at the end of this section, beginning on page 67.
} 


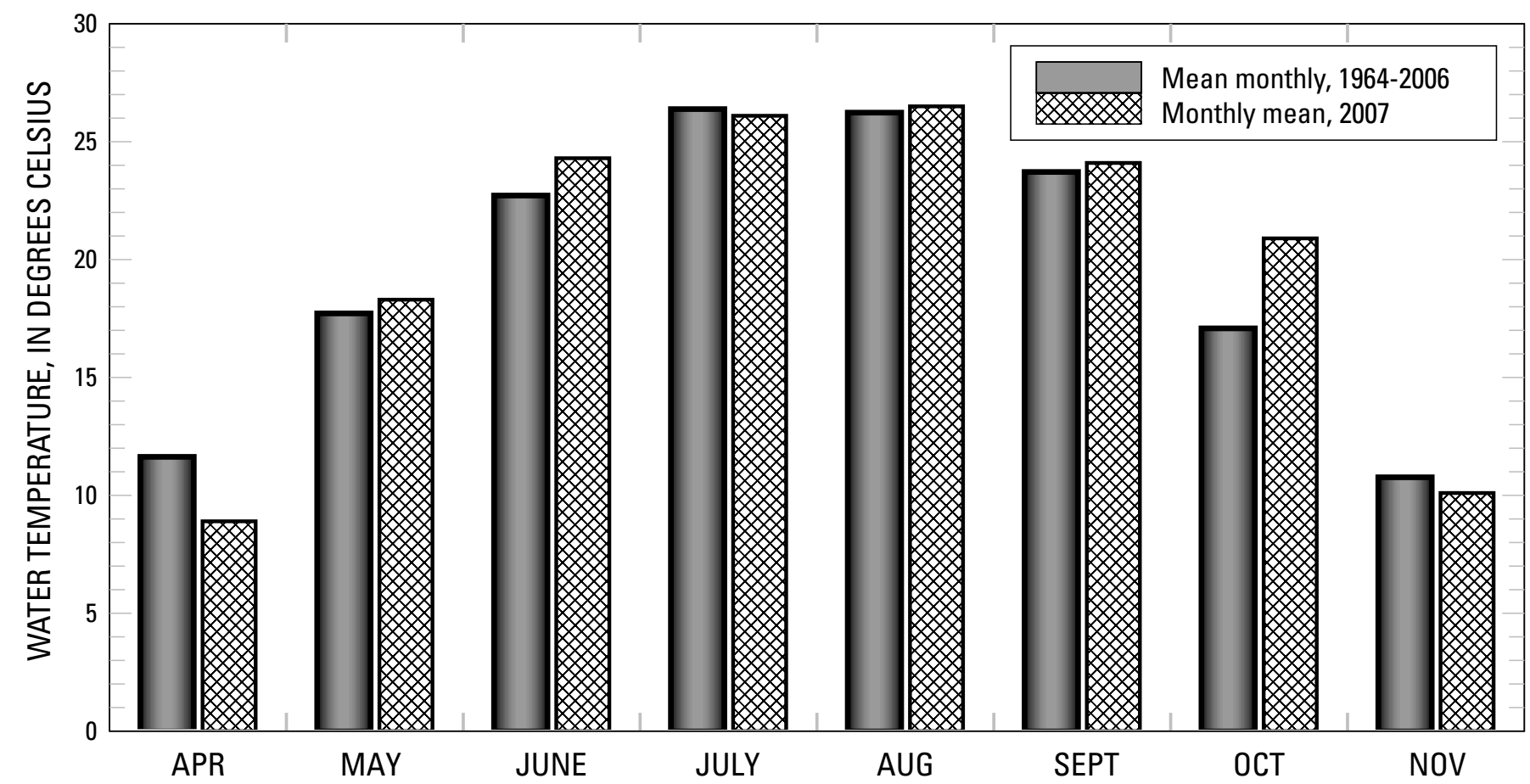

Figure 7. Water temperature in the Delaware Estuary at Benjamin Franklin Bridge at Philadelphia, Pennsylvania, April to November.

with high freshwater inflows results in decreased levels of dissolved solids and lower specific conductance, whereas low inflows have the opposite effect.

The upstream movement of seawater and the accompanying increase in chloride concentrations is an important concern for water supplies obtained from the Delaware Estuary. Water with chloride concentrations greater than 250 milligrams per liter $(\mathrm{mg} / \mathrm{L})$ is considered undesirable for domestic use, and water with concentrations exceeding $50 \mathrm{mg} / \mathrm{L}$ is unsatisfactory for chemically sensitive consumers and some industrial processes. Chloride concentrations in the estuary increase in a downstream direction, with increasing proximity to the Atlantic Ocean.

Chloride concentration was not measured directly at the monitor site at Reedy Island Jetty, Delaware. Rather, a mathematical relation between specific conductance and chloride concentration, developed on the basis of long-term field measurements of specific conductance and laboratory analyses of chloride was used to estimate chloride concentrations from specific conductance values. Chloride concentrations estimated from the relation are presented in table 17. The specific conductance-chloride relation is less reliable when chloride concentrations are less than $30 \mathrm{mg} / \mathrm{L}$, because other chemical substances may be present in quantities large enough to affect the relation. Thus, chloride concentrations estimated from specific conductance data are not presented when concentrations of less than $30 \mathrm{mg} / \mathrm{L}$ result from the relation. Instead, estimated values less than $30 \mathrm{mg} / \mathrm{L}$ are reported as $<30 \mathrm{mg} / \mathrm{L}$. Chloride concentrations at Chester, Pennsylvania (table 18), were measured directly by Kimberly Clark Chester Operations and are not derived from specific conductance data.

At Chester, the greatest daily maximum chloride concentration was $700 \mathrm{mg} / \mathrm{L}$ on September 10, 2007 (table 18). During the report year, daily maximum concentrations exceeded $50 \mathrm{mg} / \mathrm{L}$ on 70 percent of the days. The lowest daily minimum chloride concentration was $28 \mathrm{mg} / \mathrm{L}$ on April 18, 2007. Daily minimum 
concentrations exceeded $50 \mathrm{mg} / \mathrm{L}$ on 55 percent of the days. Chloride concentrations were persistently high from April 29 to September 30, 2007, when daily minimum concentrations exceeded $50 \mathrm{mg} / \mathrm{L}$ on most days.

At Reedy Island Jetty, the greatest daily maximum chloride concentration was 9,400 mg/L on February 14, 2007 (table 17). Daily maximum chloride concentrations during the report year exceeded $1,000 \mathrm{mg} / \mathrm{L}$ on 90 percent of the days. The lowest daily minimum chloride concentration was $<30 \mathrm{mg} / \mathrm{L}$ on several days in April and May 2007. Daily minimum chloride concentrations exceeded 1,000 mg/L on nearly 60 percent of the days. From December to May, daily maximum chloride concentrations at Reedy Island Jetty ranged from $<30$ to $9,400 \mathrm{mg} / \mathrm{L}$. From June to November, daily maximum chloride concentrations ranged from 3,400 to $7,900 \mathrm{mg} / \mathrm{L}$.

\section{Dissolved Oxygen}

Dissolved oxygen in water is necessary for the respiratory processes of aquatic organisms and for chemical reactions in aquatic environments. Fish and many other clean-water species require relatively high dissolved-oxygen concentrations at all times. The major source of dissolved oxygen in the Delaware Estuary is diffusion from the atmosphere, and, to a lesser extent, photosynthetic activity of aquatic plants. The principal factors that affect dissolved-oxygen concentrations in the estuary are water temperature, biochemical oxygen demand, freshwater inflow, phytoplankton, turbidity, salinity, and tidal- and wind-driven mixing.

Concentrations of dissolved oxygen at several sites on the Delaware Estuary have been measured since 1962 by the USGS. Two of these sites, Delaware River at Benjamin Franklin Bridge at Philadelphia, Pennsylvania, and Delaware River at Chester, Pennsylvania, have nearly continuous records and are in the reach of the estuary most affected by effluent discharges. The mean, and minimum daily mean, dissolvedoxygen concentrations from July to September at these stations during each of the 1965-2007 report years are shown in figure 8. Although concentrations have increased considerably over this 43-year period, mean concentrations can vary considerably from year to year.

Concentrations of dissolved oxygen in the Delaware Estuary generally are greatest near Trenton and decrease in a downstream direction. In an area just downstream of the Benjamin Franklin Bridge, concentrations commonly reach minimum levels. During the report year, daily mean concentrations of dissolved oxygen at the Benjamin Franklin Bridge monitor site were lowest in mid-June, and the lowest recorded daily mean concentration was $3.2 \mathrm{mg} / \mathrm{L}$ on June 13 (table 19). Daily mean concentrations of dissolved oxygen were consistently $6.0 \mathrm{mg} / \mathrm{L}$ or greater on all days from April 1 to May 21; September 25 to October 3; and October 13 to November 30, 2007. At Chester, daily mean dissolved-oxygen concentrations were lowest in mid-June, and the lowest recorded daily mean concentration was $4.7 \mathrm{mg} / \mathrm{L}$ on June 13, 2007 (table 20).

Histograms of hourly dissolved-oxygen concentrations at the Benjamin Franklin Bridge and Chester monitor sites during the critical summer period-July to September 2007_are presented in figure 9. Hourly concentrations at the Benjamin Franklin Bridge were $4 \mathrm{mg} / \mathrm{L}$ or less in nearly 14 percent of this period. At Chester, hourly dissolved-oxygen concentrations were $4 \mathrm{mg} / \mathrm{L}$ or less during nearly 3 percent of the 2007 critical summer period. Dissolved-oxygen concentrations less than $4 \mathrm{mg} / \mathrm{L}$ can have adverse, and possibly lethal, effects on fish and other aquatic organisms. 


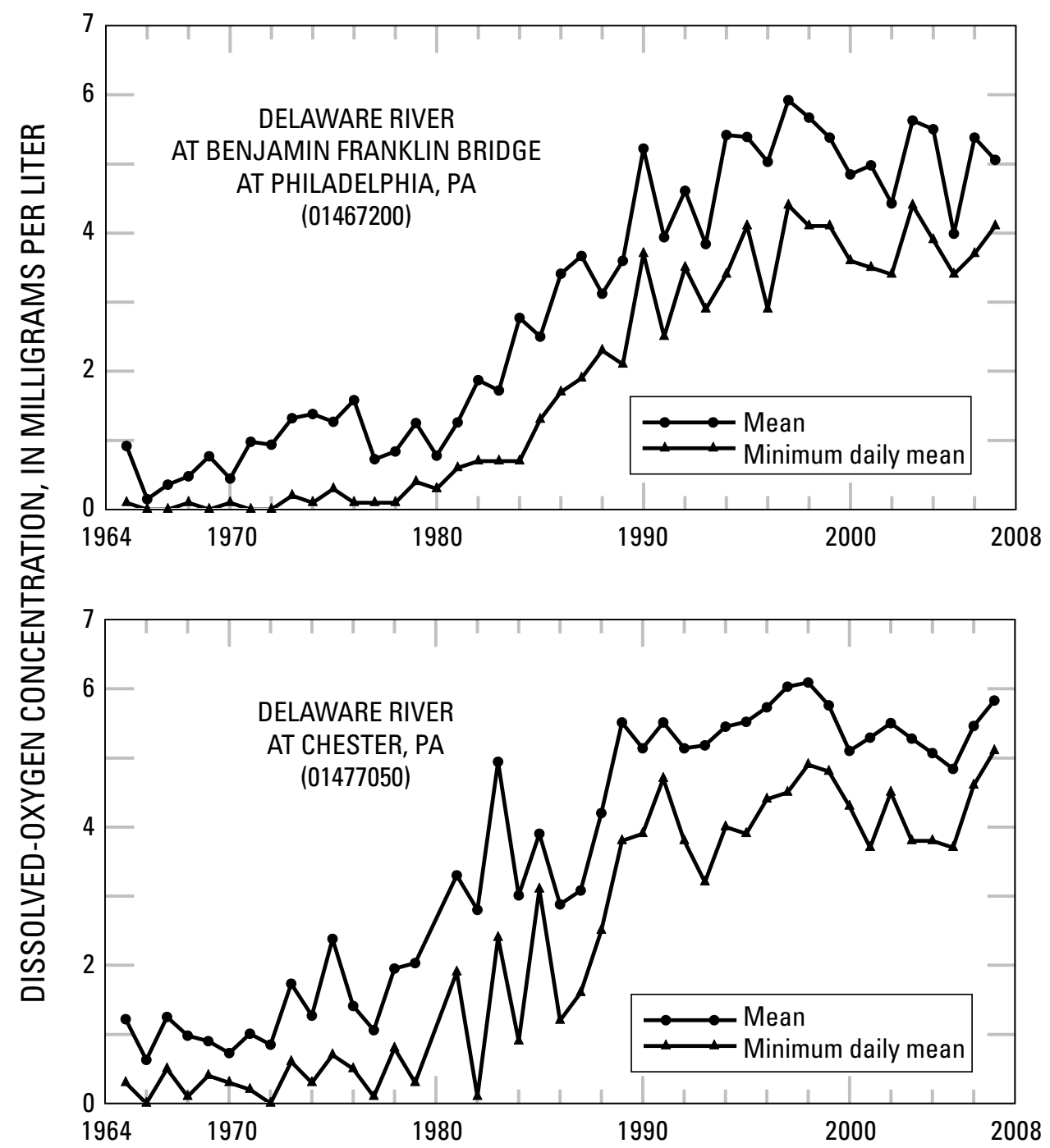

Figure 8. Mean and minimum daily mean dissolved-oxygen concentrations from July to September at two monitor sites on the Delaware Estuary, 1965-2007.

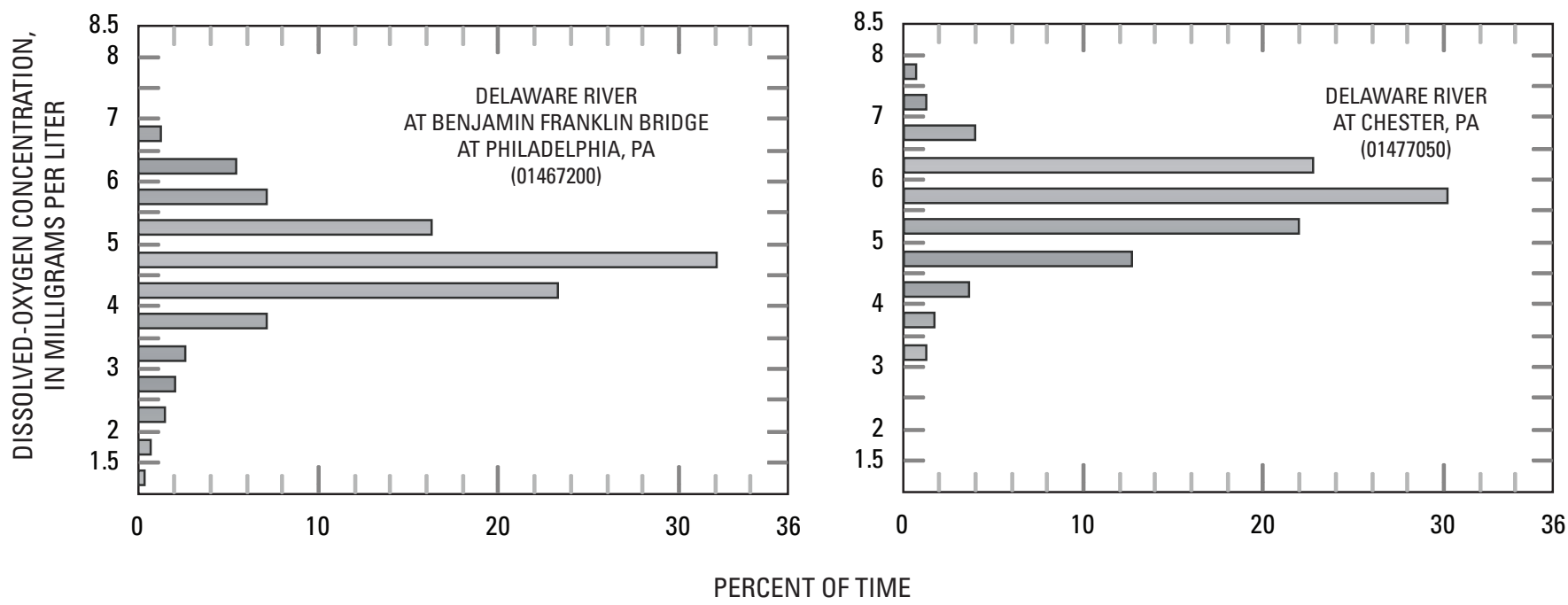

Figure 9. Distribution of hourly dissolved-oxygen concentrations at two monitor sites on the Delaware Estuary, July to September 2007. 


\section{Hydrogen-Ion Activity (pH)}

The $\mathrm{pH}$ of a solution is a measure of the effective concentration (activity) of dissolved hydrogen ions. Solutions having $\mathrm{pH}$ less than 7 are characterized as acidic, whereas solutions with $\mathrm{pH}$ greater than 7 are considered basic or alkaline. The $\mathrm{pH}$ of uncontaminated surface water generally ranges from 6.5 to 8.5. Major factors affecting the $\mathrm{pH}$ of surface water include the geologic composition of the drainage basin and human inputs, including wastewater discharges. In addition, photosynthetic activity, and dissolved gases including carbon dioxide, hydrogen sulfide, and ammonia can have a considerable effect on $\mathrm{pH}$. During the report year, $\mathrm{pH}$ was measured seasonally at the Benjamin Franklin Bridge and Chester monitor sites, and continuously at the Reedy Island Jetty site. During these periods, the ranges of daily median $\mathrm{pH}$ measured at these stations were as follows: Benjamin Franklin Bridge, 7.1 to 7.5; Chester, 6.9 to 7.4; and Reedy Island Jetty, 7.1 to 7.9. Generally, the $\mathrm{pH}$ of water in the Delaware Estuary is lowest near Trenton, New Jersey, and increases (that is, water becomes more alkaline) in a downstream direction. The $\mathrm{pH}$ of water in the Delaware Estuary between the Benjamin Franklin Bridge and Reedy Island Jetty is not a limiting factor for aquatic health or other beneficial uses of the water. 


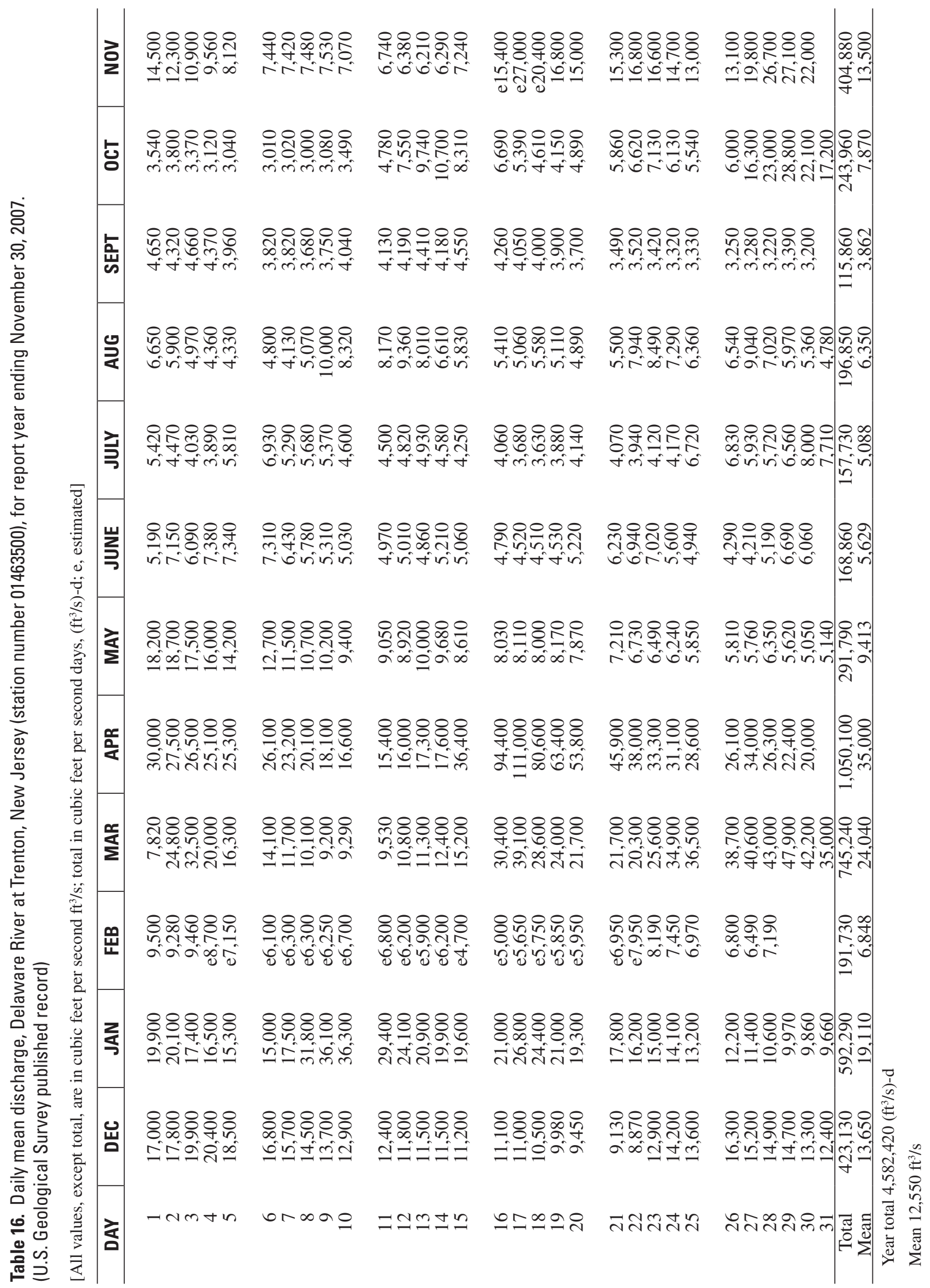




\begin{tabular}{|c|c|c|c|c|c|c|c|c|}
\hline \multirow{2}{*}{ 흘 } & \multirow{2}{*}{ 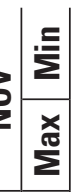 } & 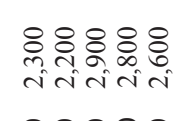 & 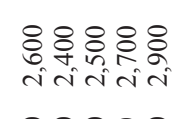 & 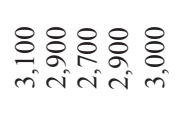 & 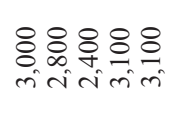 & 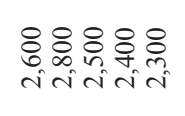 & 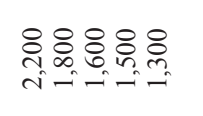 & 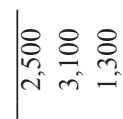 \\
\hline & & 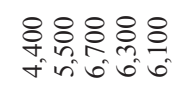 & 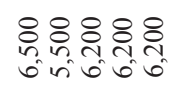 & 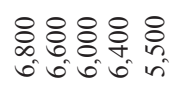 & 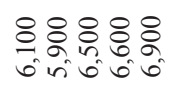 & 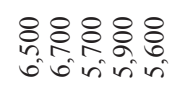 & 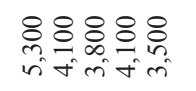 & 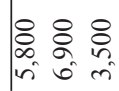 \\
\hline \multirow{2}{*}{ 능 } & $\bar{\Sigma}$ & 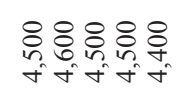 & 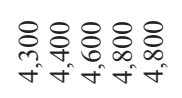 & 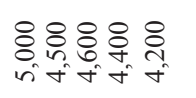 & 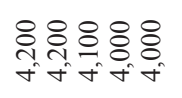 & 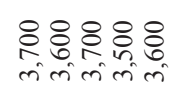 & 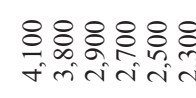 & \\
\hline & \begin{tabular}{|l|}
$x$ \\
$\mathbf{m}$ \\
$\mathbf{m}$
\end{tabular} & 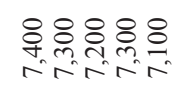 & 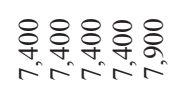 & 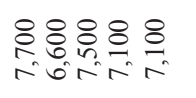 & 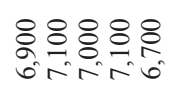 & 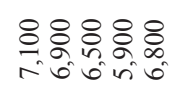 & 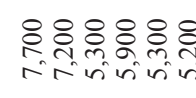 & \\
\hline \multirow{2}{*}{ 占 } & $\underline{\Sigma}$ & 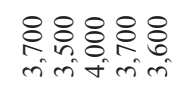 & $\begin{array}{l}8 \\
\text { | } \\
\text { m } \\
\text { miñ }\end{array}$ & 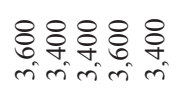 & 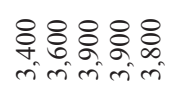 & 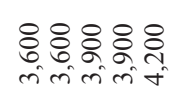 & 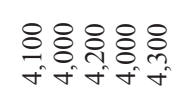 & \\
\hline & 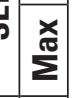 & 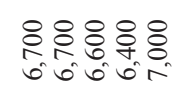 & $\mid \begin{array}{l}88 \% \\
1 \\
1\end{array}$ & 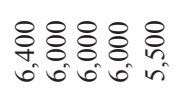 & 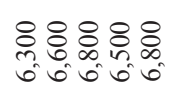 & 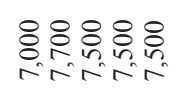 & 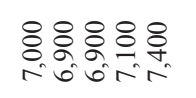 & \\
\hline \multirow{2}{*}{ 旁 } & $\overline{\mathbf{E}}$ & 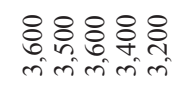 & 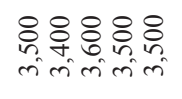 & 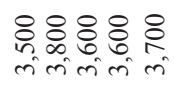 & 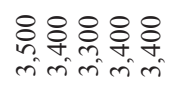 & 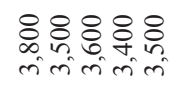 & 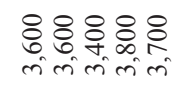 & \\
\hline & \begin{tabular}{|l|} 
\\
\\
\\
\end{tabular} & 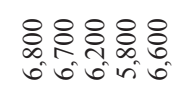 & 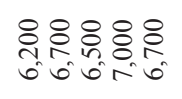 & 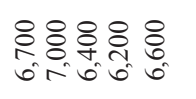 & 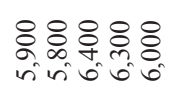 & 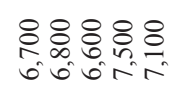 & 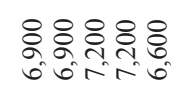 & \\
\hline \multirow{2}{*}{ 方 } & $\bar{\Sigma}$ & 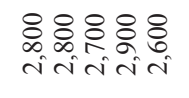 & 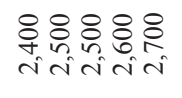 & 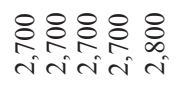 & 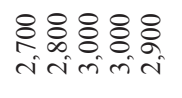 & 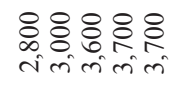 & $8:$ & \\
\hline & 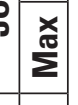 & 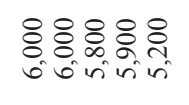 & 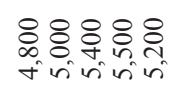 & 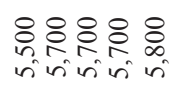 & 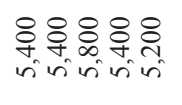 & 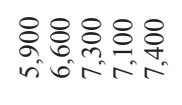 & & \\
\hline \multirow{2}{*}{ 岂 } & $\bar{\Sigma}$ & 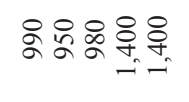 & ৪্রి & 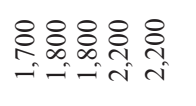 & 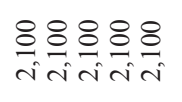 & 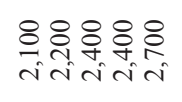 & 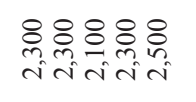 & \\
\hline & 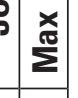 & 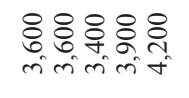 & 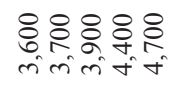 & 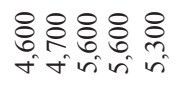 & 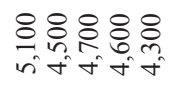 & 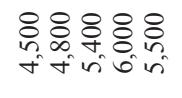 & 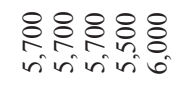 & \\
\hline \multirow{2}{*}{ 彥 } & $\bar{\Sigma}$ & চ্ণি & 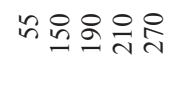 & 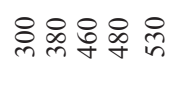 & 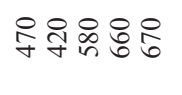 & 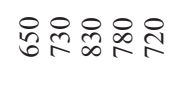 & \&: & \\
\hline & $\begin{array}{l}\mathbf{x} \\
\mathbf{m} \\
\mathbf{m} \\
\end{array}$ & 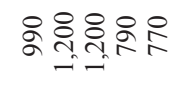 & : & 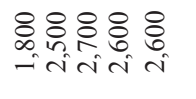 & 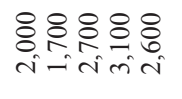 & 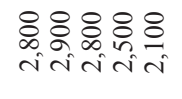 & 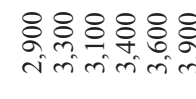 & \\
\hline \multirow{2}{*}{$\frac{\alpha}{\frac{\alpha}{\alpha}}$} & $=$ & 형워용 & 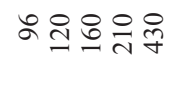 & 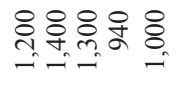 & 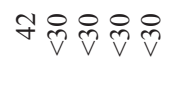 & 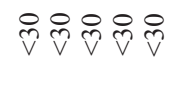 & 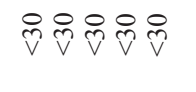 & $\rightarrow 8$ \\
\hline & $\begin{array}{l}x \\
\mathbf{m} \\
\mathbf{m} \\
\end{array}$ & 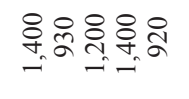 & 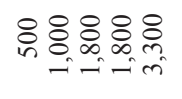 & 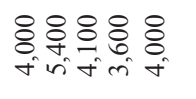 & 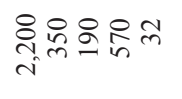 & రిలిలి & 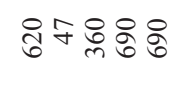 & \\
\hline \multirow{2}{*}{ 哭 } & 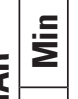 & 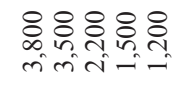 & 욤유. & 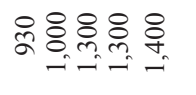 & 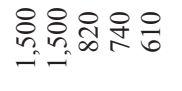 & 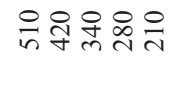 & & \\
\hline & $=\begin{array}{l}x \\
\mathbf{m} \\
\mathbf{m}\end{array}$ & 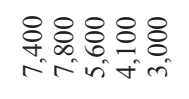 & 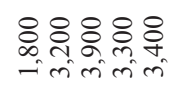 & 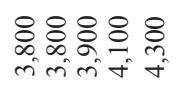 & 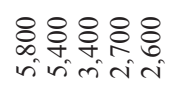 & \&: & 정유윳요 & \\
\hline \multirow{2}{*}{ 出 } & $\bar{\Sigma}$ & 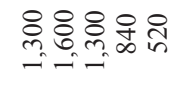 & 뉸응옹유용 & 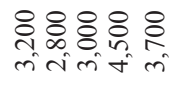 & 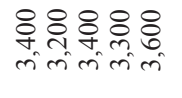 & 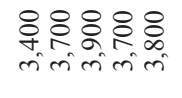 & 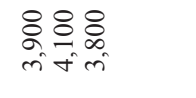 & \\
\hline & $\begin{array}{l}x \\
\text { mat } \\
\mathbf{m} \\
\end{array}$ & $\begin{array}{l}8: 8: 8 \\
8: 08: \\
\text { ninti }\end{array}$ & 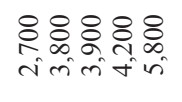 & 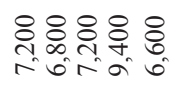 & 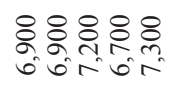 & 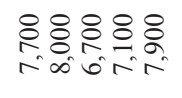 & 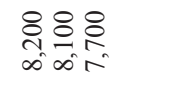 & \\
\hline \multirow{2}{*}{$\frac{z}{5}$} & $\bar{\Sigma}$ & 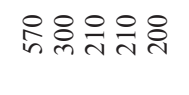 & 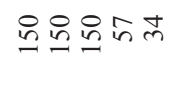 & mং: & 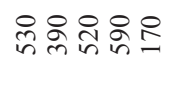 & 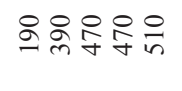 & & \\
\hline & $\begin{array}{l}x \\
\substack{\mathbf{m} \\
\mathbf{m}} \\
\end{array}$ & 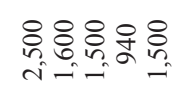 & $\mathrm{O}_{-}$ & 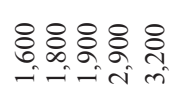 & 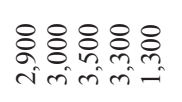 & 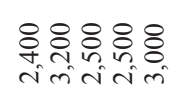 & 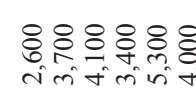 & \\
\hline \multirow{2}{*}{ 㟔 } & E & 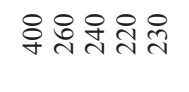 & 윳엥워웜 & 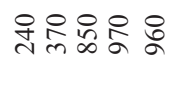 & 음영옷으용 & 옹용은욤 & 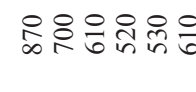 & \\
\hline & \begin{tabular}{|l|} 
\\
a \\
\\
\end{tabular} & 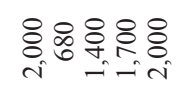 & 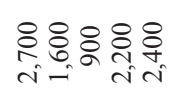 & 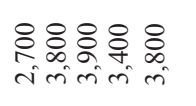 & 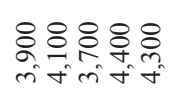 & 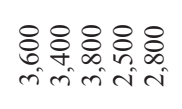 & & \\
\hline & 衣 & $-r$ & oro & $=\simeq 9$ & $\stackrel{2}{\sim} \underset{\sim}{\sim} \Omega$ ㄱ. & 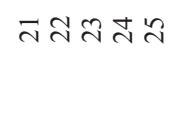 & & \\
\hline
\end{tabular}




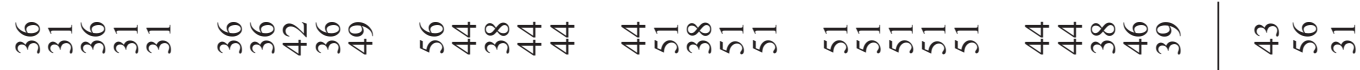

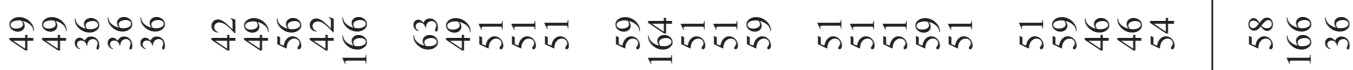

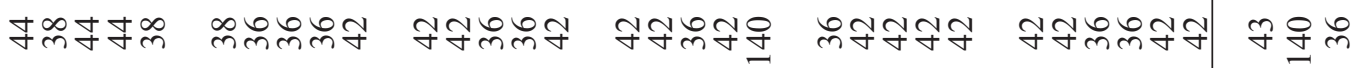

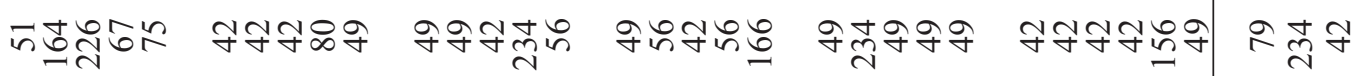

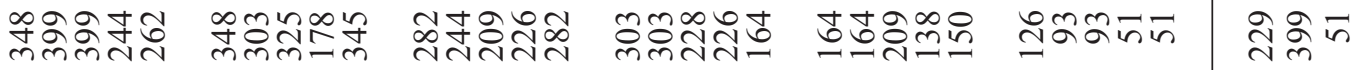

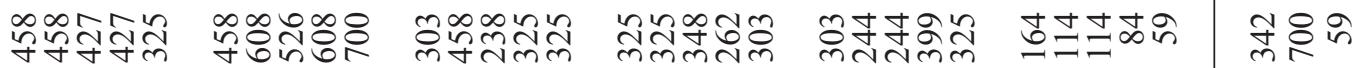

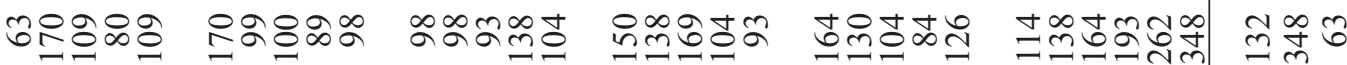

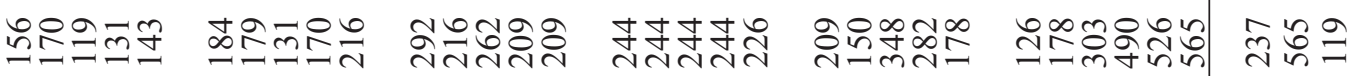

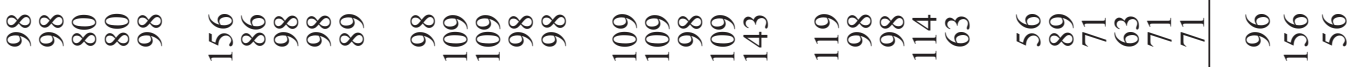

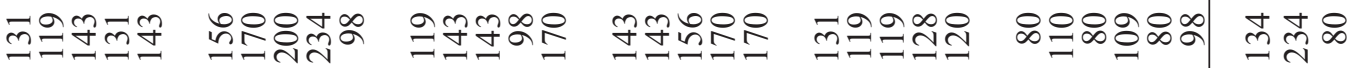

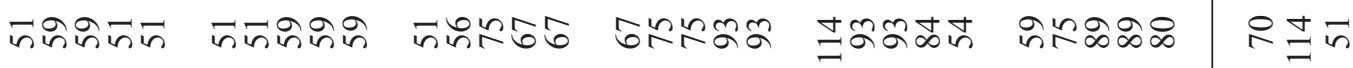

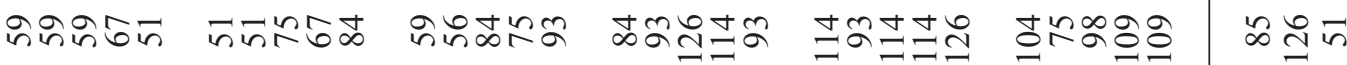

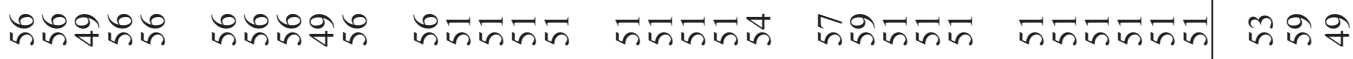

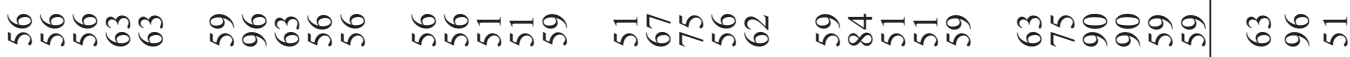

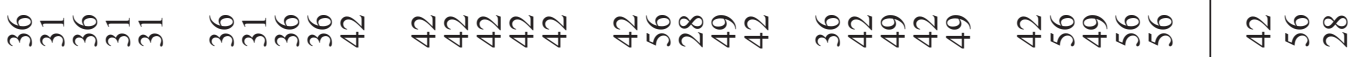

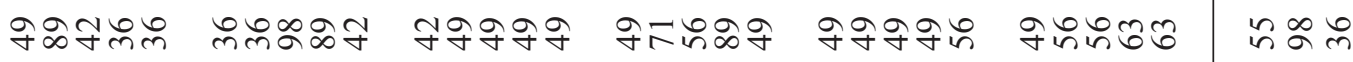

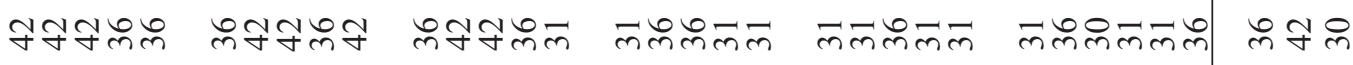

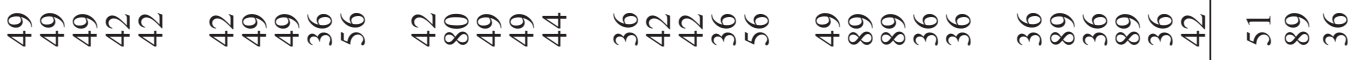

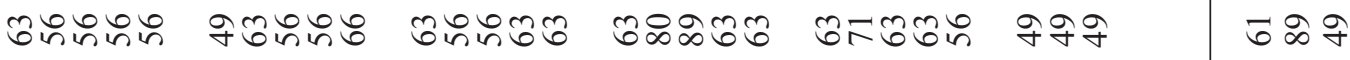

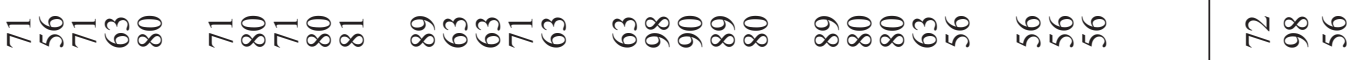

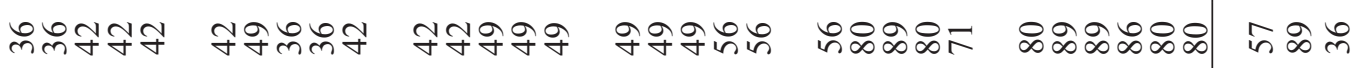

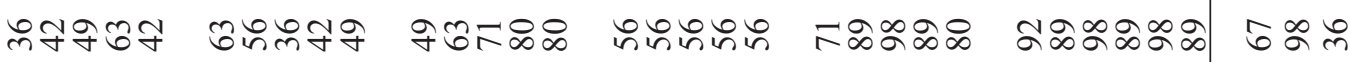

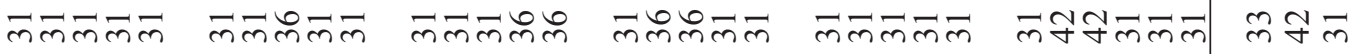

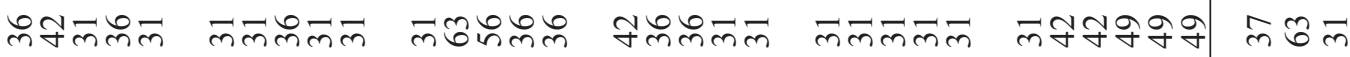

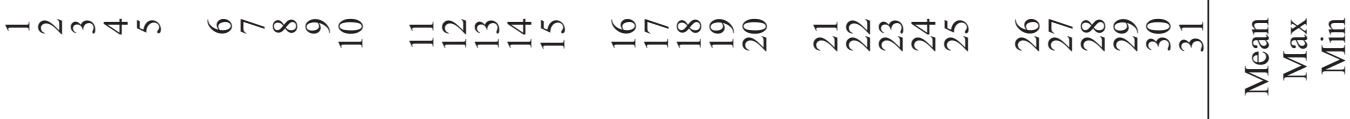


Table 19. Daily mean dissolved-oxygen concentration, Delaware River at Benjamin Franklin Bridge at Philadelphia, Pennsylvania (station number 01467200), April 1 to November 30, 2007.

(U.S. Geological Survey published record)

[Concentrations in milligrams per liter; Max, maximum value; Min, minimum value; --, missing data]

\begin{tabular}{|c|c|c|c|c|c|c|c|c|}
\hline DAY & APR & MAY & JUNE & JULY & AUG & SEPT & OCT & NOV \\
\hline 1 & 11.1 & 9.0 & 4.9 & 5.2 & 4.6 & -- & 6.0 & 8.5 \\
\hline 2 & 11.2 & 8.9 & 5.0 & 5.3 & 4.6 & -- & 6.0 & 8.8 \\
\hline 3 & 11.2 & 9.0 & 4.6 & 5.4 & 4.7 & -- & 6.0 & 8.9 \\
\hline 4 & 11.1 & 9.0 & 4.3 & 5.5 & 4.7 & -- & 5.8 & 9.1 \\
\hline 5 & 10.9 & 8.9 & 4.0 & 5.3 & 4.7 & -- & 5.8 & 9.3 \\
\hline 6 & 10.9 & 8.9 & 3.9 & 5.1 & 4.5 & -- & 5.7 & 9.3 \\
\hline 7 & 10.8 & 8.6 & 3.9 & 5.1 & 4.4 & -- & 5.7 & 9.5 \\
\hline 8 & 10.6 & 8.5 & 3.8 & 5.2 & 4.4 & -- & 5.7 & 9.5 \\
\hline 9 & 10.8 & 8.1 & 3.7 & 5.3 & 4.6 & -- & 5.9 & 9.4 \\
\hline 10 & 11.0 & 7.8 & 3.8 & 5.3 & 4.6 & -- & 5.7 & 9.4 \\
\hline 11 & 11.1 & 7.6 & 3.7 & 5.2 & 4.7 & -- & 5.6 & 9.3 \\
\hline 12 & 11.1 & 7.5 & 3.4 & 4.8 & 4.7 & -- & 5.9 & 9.4 \\
\hline 13 & 11.3 & 7.3 & 3.2 & 4.7 & 4.8 & -- & 6.3 & 9.4 \\
\hline 14 & 11.3 & 7.4 & 3.4 & 4.7 & 4.8 & -- & 6.5 & 9.2 \\
\hline 15 & 11.0 & 7.5 & 3.4 & 4.8 & 4.8 & -- & 6.7 & 9.3 \\
\hline 16 & 10.8 & 7.5 & 3.4 & 5.0 & 4.7 & -- & 6.8 & 9.6 \\
\hline 17 & 10.6 & 6.9 & 3.6 & 5.0 & 4.7 & -- & 6.7 & 10.1 \\
\hline 18 & 11.1 & 6.9 & 3.8 & 4.8 & 4.6 & 5.4 & 6.5 & 10.6 \\
\hline 19 & 11.4 & 6.5 & 4.0 & 4.6 & 4.6 & 5.6 & 6.4 & 11.1 \\
\hline 20 & 11.5 & 6.3 & 3.9 & 4.7 & 4.4 & 5.7 & 6.4 & 11.6 \\
\hline 21 & 11.3 & 6.0 & 3.9 & 4.9 & 4.5 & 5.8 & 6.4 & 11.7 \\
\hline 22 & 11.1 & 5.8 & 4.3 & 5.3 & 4.6 & 5.8 & 6.5 & 11.7 \\
\hline 23 & 10.8 & 5.4 & 4.8 & 5.4 & 4.7 & 5.8 & 6.7 & 11.9 \\
\hline 24 & 10.4 & 5.3 & 5.1 & 5.5 & 4.7 & 5.9 & 6.9 & 12.0 \\
\hline 25 & 10.1 & 5.3 & 5.3 & 5.5 & 4.6 & 6.0 & 6.9 & 12.0 \\
\hline 26 & 9.8 & 5.3 & 5.4 & 5.3 & 4.1 & 6.1 & 7.1 & 12.0 \\
\hline 27 & 9.4 & 5.0 & 5.4 & 5.3 & -- & 6.1 & 7.1 & 12.0 \\
\hline 28 & 9.2 & 4.8 & 5.3 & 5.2 & -- & 6.0 & 7.8 & 12.1 \\
\hline 29 & 9.2 & 4.9 & 5.2 & 5.0 & -- & 6.1 & 8.1 & 12.4 \\
\hline 30 & 9.1 & 5.0 & 5.1 & 4.8 & -- & 6.2 & 8.2 & 12.6 \\
\hline 31 & & 5.0 & & 4.7 & -- & & 8.4 & \\
\hline Mean & 10.7 & 7.0 & 4.2 & 5.1 & 4.6 & 5.9 & 6.5 & 10.4 \\
\hline Max & 11.5 & 9.0 & 5.4 & 5.5 & 4.8 & 6.2 & 8.4 & 12.6 \\
\hline Min & 9.1 & 4.8 & 3.2 & 4.6 & 4.1 & 5.4 & 5.6 & 8.5 \\
\hline
\end{tabular}


Table 20. Daily mean dissolved-oxygen concentration, Delaware River at Chester, Pennsylvania (station number 01477050), April 1 to November 30, 2007.

(U.S. Geological Survey published record)

[Concentrations in milligrams per liter; Max, maximum value; Min, minimum value; --, missing data]

\begin{tabular}{|c|c|c|c|c|c|c|c|c|}
\hline DAY & APR & MAY & JUNE & JULY & AUG & SEPT & OCT & NOV \\
\hline 1 & 11.7 & 9.4 & 6.5 & 5.6 & 5.4 & 5.2 & 7.1 & 7.3 \\
\hline 2 & 11.6 & 9.1 & 6.1 & 5.8 & 5.3 & 5.3 & 7.1 & 7.5 \\
\hline 3 & 11.5 & 8.9 & -- & 6.0 & 5.4 & 5.5 & 7.1 & 7.8 \\
\hline 4 & 11.4 & 8.7 & -- & 6.3 & 5.4 & 5.5 & 7.1 & 8.0 \\
\hline 5 & 11.6 & 8.5 & 5.5 & 6.5 & 5.5 & 5.6 & 7.0 & 8.0 \\
\hline 6 & 11.9 & 8.7 & 5.3 & 6.2 & 5.7 & 5.6 & 6.9 & 8.3 \\
\hline 7 & 11.9 & 8.8 & 5.1 & 6.0 & 5.6 & 5.7 & 6.9 & 8.6 \\
\hline 8 & 12.1 & 8.7 & 4.9 & 6.0 & 5.5 & 5.8 & 7.1 & 8.7 \\
\hline 9 & 12.4 & 8.4 & 4.8 & 6.0 & 5.4 & 5.7 & 7.2 & 8.6 \\
\hline 10 & 12.5 & 8.3 & 4.9 & -- & 5.4 & 5.6 & -- & 8.6 \\
\hline 11 & 12.4 & 8.0 & -- & -- & 5.6 & 5.6 & 6.8 & 8.6 \\
\hline 12 & 12.4 & 7.9 & -- & 5.9 & 5.6 & 5.7 & 7.0 & 8.7 \\
\hline 13 & 12.4 & 7.9 & 4.7 & 5.8 & -- & 5.7 & 7.1 & 8.6 \\
\hline 14 & 12.5 & 7.9 & 5.1 & 5.8 & -- & 5.8 & 7.1 & 8.5 \\
\hline 15 & 12.4 & 8.0 & 4.9 & 6.1 & -- & 5.8 & 7.1 & 8.5 \\
\hline 16 & 13.0 & 8.0 & 4.8 & 6.0 & 5.7 & 6.0 & 6.9 & -- \\
\hline 17 & 13.2 & 7.6 & 4.9 & 5.9 & 5.5 & 6.2 & 6.9 & -- \\
\hline 18 & 13.1 & 7.4 & 4.9 & 5.9 & 5.3 & 6.5 & 6.6 & -- \\
\hline 19 & 13.0 & 7.1 & 5.1 & 5.6 & 5.2 & 6.7 & -- & -- \\
\hline 20 & 13.0 & 7.0 & 5.0 & 5.6 & 5.1 & 6.7 & -- & -- \\
\hline 21 & 12.7 & 6.9 & 5.0 & 5.7 & 5.4 & 6.6 & -- & -- \\
\hline 22 & 12.4 & 6.8 & 5.2 & 5.8 & -- & 6.5 & -- & -- \\
\hline 23 & 12.1 & 6.7 & 5.3 & 6.0 & -- & 6.4 & -- & -- \\
\hline 24 & 11.7 & 6.8 & 5.5 & 6.2 & -- & 6.5 & -- & -- \\
\hline 25 & 11.4 & 6.8 & 5.7 & 6.2 & -- & 6.6 & -- & 9.5 \\
\hline 26 & 11.1 & 6.8 & 5.7 & 6.0 & -- & 6.6 & -- & 9.6 \\
\hline 27 & -- & 6.7 & 5.8 & 5.8 & -- & 6.6 & -- & 9.8 \\
\hline 28 & -- & 6.6 & 6.0 & 5.8 & 5.3 & 6.7 & -- & 10.0 \\
\hline 29 & -- & 6.5 & 5.8 & 5.5 & 5.3 & 6.8 & -- & 10.1 \\
\hline 30 & -- & 6.7 & 5.6 & 5.5 & 5.3 & 6.9 & 7.2 & 10.4 \\
\hline 31 & & 6.6 & & 5.4 & 5.2 & & 7.2 & \\
\hline Mean & 12.2 & 7.7 & 5.3 & 5.9 & 5.4 & 6.1 & 7.0 & 8.7 \\
\hline Max & 13.2 & 9.4 & 6.5 & 6.5 & 5.7 & 6.9 & 7.2 & 10.4 \\
\hline Min & 11.1 & 6.5 & 4.7 & 5.4 & 5.1 & 5.2 & 6.6 & 7.3 \\
\hline
\end{tabular}




\title{
Appendix A
}

\author{
Temporary Spill Mitigation Program \\ for \\ Neversink, Pepacton, and Cannonsville Reservoirs
}

On April 21, 2004, the Parties to the 1954 U.S. Supreme Court Decree (Decree Parties) approved an interim program for managing releases from the New York City Neversink, Pepacton and Cannonsville Reservoirs (NYC Delaware Basin Reservoirs). That interim program was embodied in Delaware River Basin Commission (DRBC) Resolution No. 2004-3 Docket No. D-77-20 (Revision 7). In approving that resolution, the Decree Parties committed to continuing discussions to develop and implement by May 31, 2007 a long-term flexible program to manage releases from the NYC Delaware Basin Reservoirs to better address fisheries in the tailwaters below those reservoirs; the Decree Parties agreed that implementation of such a program required consideration of other related issues.

The Decree Parties agree that reduction of spill volumes from the NYC Delaware Basin Reservoirs during flood events is a related issue that should be considered in the development of the long-term flexible program. The Decree Parties also agree that reduction of NYC Delaware Basin Reservoir spill volumes should not be delayed until final approval of a long-term flexible program occurs, and hereby agree to implement a temporary spill mitigation program through May 31, 2007.

During above normal hydrologic conditions that result in full or nearly full storage in the NYC Delaware Basin Reservoirs, the temporary spill mitigation program described below will be implemented to reduce the volume of water spilled from these reservoirs. The program will attempt to limit excess spillage through supplemental releases from the NYC Delaware Basin Reservoirs. The program shall be in effect through May 31, 2007. This temporary program is not part of any regular release program and does not establish a precedent for any future releases or actions.

Although the total volume of water spilled from the NYC Delaware Basin Reservoirs may be reduced by this temporary program, it is unlikely that peak flows downstream of these reservoirs will be significantly further reduced. The NYC Delaware Basin Reservoirs provide substantial attenuation of peak flows downstream even when one or more of the reservoirs are spilling. The reservoirs were not designed as flood control reservoirs and do not contain release works capable of releasing water at rates necessary for effective flood management operation; consequently, the Decree Parties continue to strongly urge communities downstream of the reservoirs to take all necessary and prudent actions to improve flood preparedness and increase awareness of flood potential.

\section{Temporary Reservoir Spill Mitigation Program:}

1. Upon approval of this agreement by the Decree Parties, NYC will implement a temporary program to achieve limited reduction of NYC Delaware Basin Reservoir spills through supplemental releases.

2. For the period ending May 31, 2007, whenever the usable storage in the NYC Delaware Basin Reservoirs is above the $80 \%$ rule curve as shown in Figure 1. in lieu of the releases otherwise required under Docket D-77-20 (Revision 7), supplemental releases from the NYC Delaware Basin Reservoirs will be made in accordance with the individual rule curves shown on Figure 2 and at rates as shown in Table 1. In order to provide for such releases, it is agreed that the operational assumptions used for modeling analyses and stipulated in paragraph 3 will apply throughout the period this program remains in effect.

3. The releases under this program have been modeled using the OASIS model and are based upon an operational assumption of a running daily average diversion by the City of not more than $610 \mathrm{mgd}$, combined, from the NYC Delaware Basin Reservoirs. The habitat flow targets, in accordance with Revision 7, continue to apply when storage is above the $80 \%$ rule curve. 
Figure 1

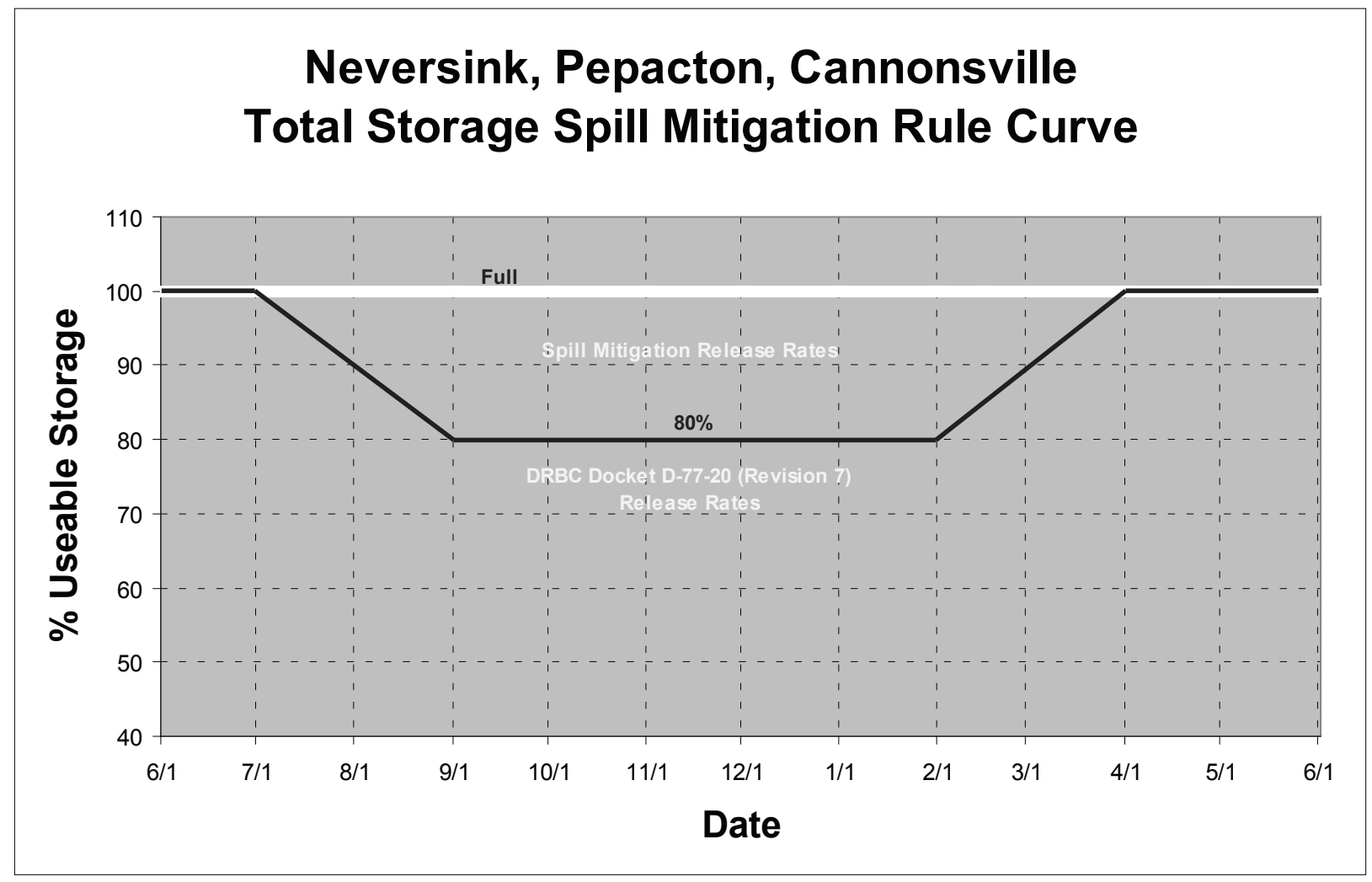

Figure 2

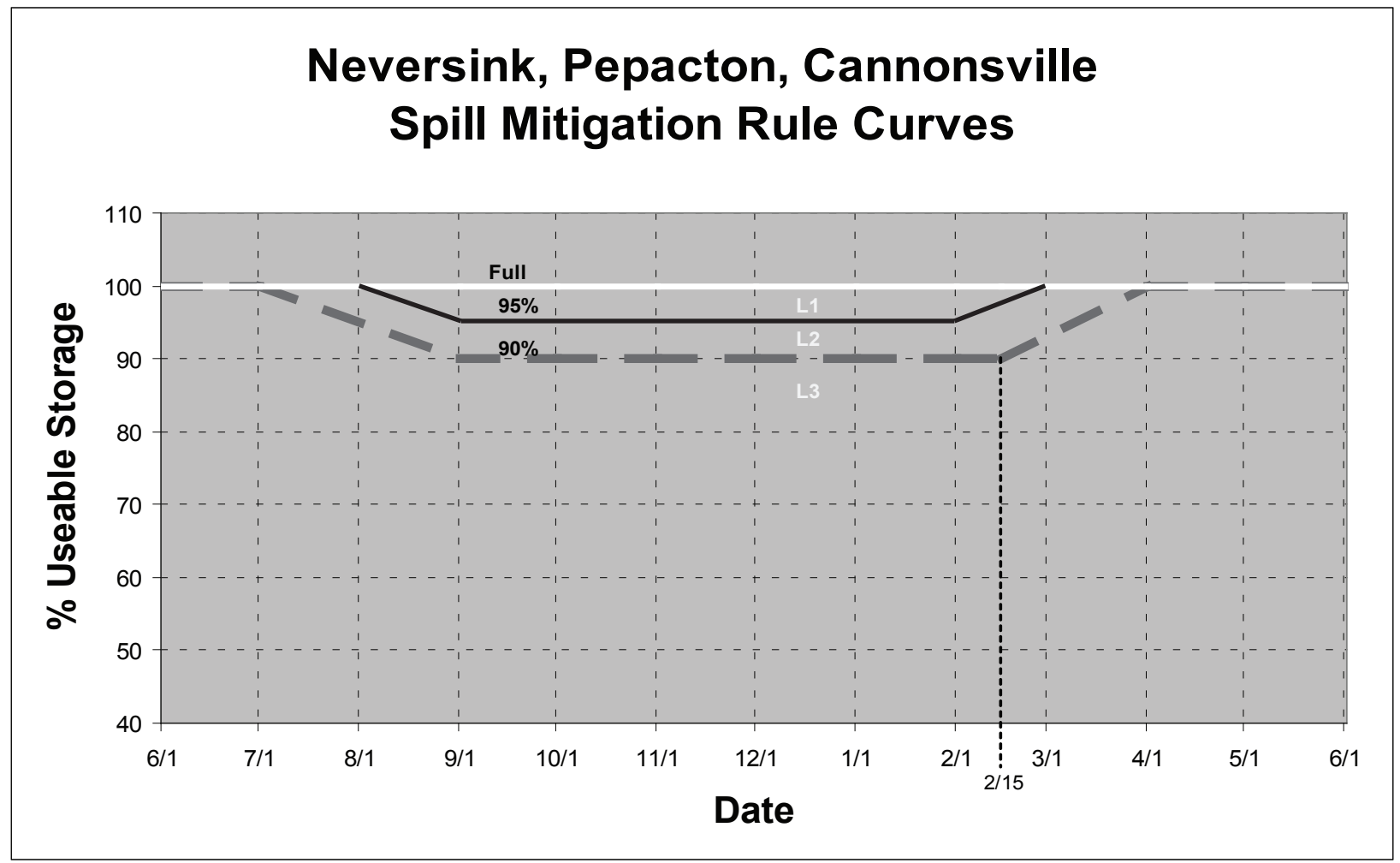


Table 1

\begin{tabular}{|l|c|c|c|c|c|c|}
\hline \multirow{2}{*}{$\begin{array}{c}\text { Release } \\
\text { Level }\end{array}$} & \multicolumn{5}{|c|}{ Release Rates (cfs) } \\
\cline { 2 - 7 } & \multicolumn{3}{|c|}{ Spring/Fall } & \multicolumn{3}{c|}{ Winter } \\
\hline & Cannonsville & Pepacton & Neversink & Cannonsville & Pepacton & Neversink \\
\hline L1 & 1000 & 700 & 190 & 1000 & 700 & 190 \\
\hline L2 & 275 & 200 & 85 & 250 & 185 & 85 \\
\hline L3 & 140 & 100 & 75 & 110 & 85 & 65 \\
\hline
\end{tabular}

\begin{tabular}{|ll|}
\hline Spring/Fall: & May 1-May 31 and Sept. 15-Sept. 30 \\
Winter: & October 1-April 30 \\
\hline
\end{tabular}

4. Controlled reservoir releases will be made in accordance with the following:

i. The flood stage for the West Branch Delaware River at Hale Eddy is 11 feet. Accordingly, supplemental releases from Cannonsville Reservoir will not be made when the river stage for the West Branch Delaware River at Hale Eddy is above 9 feet, or is forecasted to be above 9 feet within 48 hours of a planned supplemental release from Cannonsville Reservoir. This guidance may be modified at any time if additional information demonstrates that a lower cautionary stage should be used to limit the supplemental releases.

ii. The flood stage for the East Branch Delaware River at Fishs Eddy is $13 \mathrm{ft}$. Accordingly, supplemental releases will not be made when the river stage for the East Branch Delaware River at Fishs Eddy is above $11 \mathrm{ft}$. or is forecast to be above $11 \mathrm{ft}$. within 48 hours of a planned supplemental release from Pepacton Reservoir. This guidance may be modified at any time if additional information demonstrates that a lower cautionary stage should be used to limit the supplemental releases.

iii. The flood stage for the Neversink River at Bridgeville is 13 feet. Accordingly, supplemental releases will not be made when the river stage for the Neversink River at Bridgeville is above 12 feet, or is forecast to be above 12 feet within 48 hours of a planned supplemental release from Neversink Reservoir. This guidance may be modified at any time if additional information demonstrates that a lower cautionary stage should be used to limit the supplemental releases.

iv. Supplemental releases may be suspended from the respective reservoir if ice conditions threaten flood prone areas of the Neversink River below Neversink Reservoir, East Branch Delaware River below Pepacton Reservoir, or West Branch Delaware River below Cannonsville Reservoir.

v. Supplemental releases will be designed so that the combined discharge from the reservoirs and their respective spillways do not exceed flow rates as detailed in Table 2 below. All controlled releases will be reduced to the conservation releases in Table 3 when the spillway discharge exceeds these flow rates.

vi. To more naturally effect downward transitions between release levels identified in Figures 1 and 2 and Table 1, supplemental release rates shall be ramped generally over a three-day period at Cannonsville and Pepacton Reservoirs and a two-day period at Neversink Reservoir, but in increments no less than $10 \mathrm{cfs}$ at any reservoir. 
Table 2

\begin{tabular}{|l|c|}
\hline \multicolumn{1}{|c|}{ Reservoir } & Maximum Combined Spill/ Release Flow Rate \\
\hline Neversink & $3400 \mathrm{cfs}$ \\
\hline Pepacton & $2400 \mathrm{cfs}$ \\
\hline Cannonsville & $4200 \mathrm{cfs}$ \\
\hline
\end{tabular}

Table 3. Conservation Releases

\begin{tabular}{|l|c|c|c|c|}
\hline \multirow{2}{*}{\begin{tabular}{c} 
Reservoir \\
\cline { 2 - 5 }
\end{tabular}} & Normal & $\begin{array}{c}\text { Drought } \\
\text { Watch }\end{array}$ & $\begin{array}{c}\text { Drought } \\
\text { Warning }\end{array}$ & Drought \\
\hline Cannonsville (9/1-5/31) & 45 & 38 & 32 & 23 \\
\hline Cannonsville (6/1-8/31) & 60 & 51 & 43 & 23 \\
\hline Pepacton & 35 & 30 & 25 & 19 \\
\hline Neversink & 25 & 21 & 18 & 15 \\
\hline
\end{tabular}

5. For the period ending May 31, 2007, whenever the total storage in the NYC Delaware Basin Reservoirs is below the applicable point on the $80 \%$ rule curve as shown in Figure 1, releases from the NYC Delaware Basin Reservoirs will be made and accounted for in accordance with DRBC Docket D-77-20 (Revision 7).

6. For the period ending May 31, 2007, whenever the total storage in the NYC Delaware Basin Reservoirs is above the applicable point on the $80 \%$ rule curve as shown in Figure 1 and supplemental releases are made in accordance with this spill mitigation program, to the extent necessary, habitat releases may be made to meet the habitat flow targets in accordance with DRBC Docket D-77-20 (Revision 7). There shall be no credits or debits to the 'Habitat Protection Bank' as established in Revision 7 including without limitation to the Excess Release Quantity Bank portion of the Habitat Protection Bank provided from the Excess Release Quantity.

7. The "Rainfall Event Based Temporary Spill Reduction Program for Pepacton Reservoir" effective February 8, 2006 and "Rainfall Event Based Temporary Spill Reduction Program for Neversink Reservoir" effective February 8, 2006 are hereby suspended for the effective period of this agreement.

8. The "Interim Program for Neversink Reservoir Spill Reduction" effective November 1, 2005 and the "Interim Program for Pepacton Reservoir Spill Reduction" effective November 1, 2005 are hereby suspended for the effective period of this agreement.

9. A quantity of water no greater than $50 \%$ of the water equivalent of snow pack storage in the watershed above each reservoir will be included in the storage calculation to determine the reservoir release levels in Figure 2 and Table 1.

10. This agreement will expire on May 31, 2007 and may be terminated at any time at the request of any Decree Party or may be modified with the unanimous consent of the Decree Parties. 


\section{Consent to Action by The City of New York}

Consent of the Parties to the U.S. Supreme Court Decree in New Jersey v. New York, 347 U.S. 995 (1954), approving the Temporary Spill Mitigation Program for Neversink, Pepacton and Cannonsville Reservoirs, January 3, 2007 through May 31, 2007, implemented by the City of New York.

/s/ Mark N. Mauriello

State of New Jersey Date

/s/ Kevin C. Donnelly

State of Delaware

Date

/s/ John H. Talley

State of Delaware
Date

$\frac{/ \mathrm{s} / \text { Mark Klotz }}{\text { State of New York Date }}$

/s/ Cathy Curran Myers Commonwealth of Pennsylvania Date

/s/ Paul Rush

City of New York

Date 


\title{
Appendix B
}

\author{
Temporary Spill Mitigation Program \\ for \\ Neversink, Pepacton, and Cannonsville Reservoirs
}

June 1, 2007 - September 26, 2007

On April 21, 2004, the Parties to the 1954 U.S. Supreme Court Decree (Decree Parties) approved an interim program for managing releases from the New York City Neversink, Pepacton and Cannonsville Reservoirs (NYC Delaware Basin Reservoirs). That interim program was embodied in Delaware River Basin Commission (DRBC) Resolution No. 2004-3 Docket No. D-77-20 (Revision 7). In approving that resolution, the Decree Parties committed to continuing discussions to develop and implement a long-term flexible program to manage releases from the NYC Delaware Basin Reservoirs to better address fisheries in the tailwaters below those reservoirs; the Decree Parties agreed that implementation of such a program required consideration of other related issues.

The Decree Parties agree that reduction of spill volumes from the NYC Delaware Basin Reservoirs during flood events is a related issue that should be considered in the development of the long-term flexible program. The Decree Parties also agree that reduction of NYC Delaware Basin Reservoir spill volumes should not be delayed until final approval of a long-term flexible program occurs, and hereby agree to implement a temporary spill mitigation program through September 26, 2007.

During above normal hydrologic conditions that result in full or nearly full storage in the NYC Delaware Basin Reservoirs, the temporary spill mitigation program described below will be implemented to reduce the volume of water spilled from these reservoirs. The program will attempt to limit excess spillage through spill mitigation releases from the NYC Delaware Basin Reservoirs. The program is not designed to achieve any specific void volumes in the reservoirs; rather, it provides for significantly increased releases during periods of high storage in order to reduce combined usable storage and the occurrence and duration of spills to the extent practicable. The program shall be in effect through September 26, 2007. This temporary program is not part of any regular release program and does not establish a precedent for any future releases or actions.

Although the total volume of water spilled from the NYC Delaware Basin Reservoirs may be reduced by this temporary program, it is unlikely that peak flows downstream of these reservoirs will be significantly further reduced. The NYC Delaware Basin Reservoirs provide substantial attenuation of peak flows downstream even when one or more of the reservoirs are spilling. The reservoirs were not designed as flood control reservoirs and do not contain release works capable of releasing water at rates necessary for effective flood management operation; consequently, the Decree Parties continue to strongly urge communities downstream of the reservoirs to take all necessary and prudent actions to improve flood preparedness and increase awareness of flood potential.

\section{Temporary Reservoir Spill Mitigation Program:}

1. Upon approval of this agreement by the Decree Parties, NYC will implement a temporary program to achieve limited reduction of NYC Delaware Basin Reservoir spills through spill mitigation releases.

2. For the period ending September 26, 2007, whenever the combined reservoir usable storage in the NYC Delaware Basin Reservoirs is in the Spill Mitigation Release Zone as shown in Figure 1, in lieu of the releases otherwise required under Docket D-77-20 (Revision 7), spill mitigation releases from the NYC Delaware Basin Reservoirs will be made in accordance with the individual rule curves shown on Figure 2 and at rates as shown in Table 1. In order to provide for such releases, it is agreed that the operational assumptions used for previous modeling analyses and stipulated in paragraph 3 will apply throughout the period this program remains in effect. 
3. The releases under this program are based upon an operational assumption of a running daily average diversion by the City of not more than $610 \mathrm{mgd}$, combined, from the NYC Delaware Basin Reservoirs. The habitat flow targets, in accordance with Revision 7, continue to apply when combined reservoir usable storage is in the Spill Mitigation Release Zone.

\section{Figure 1}

Delaware System Combined Reservoir Usable Storage

(Cannonsville, Pepacton, Neversink)

Spill Mitigation Rule Curve

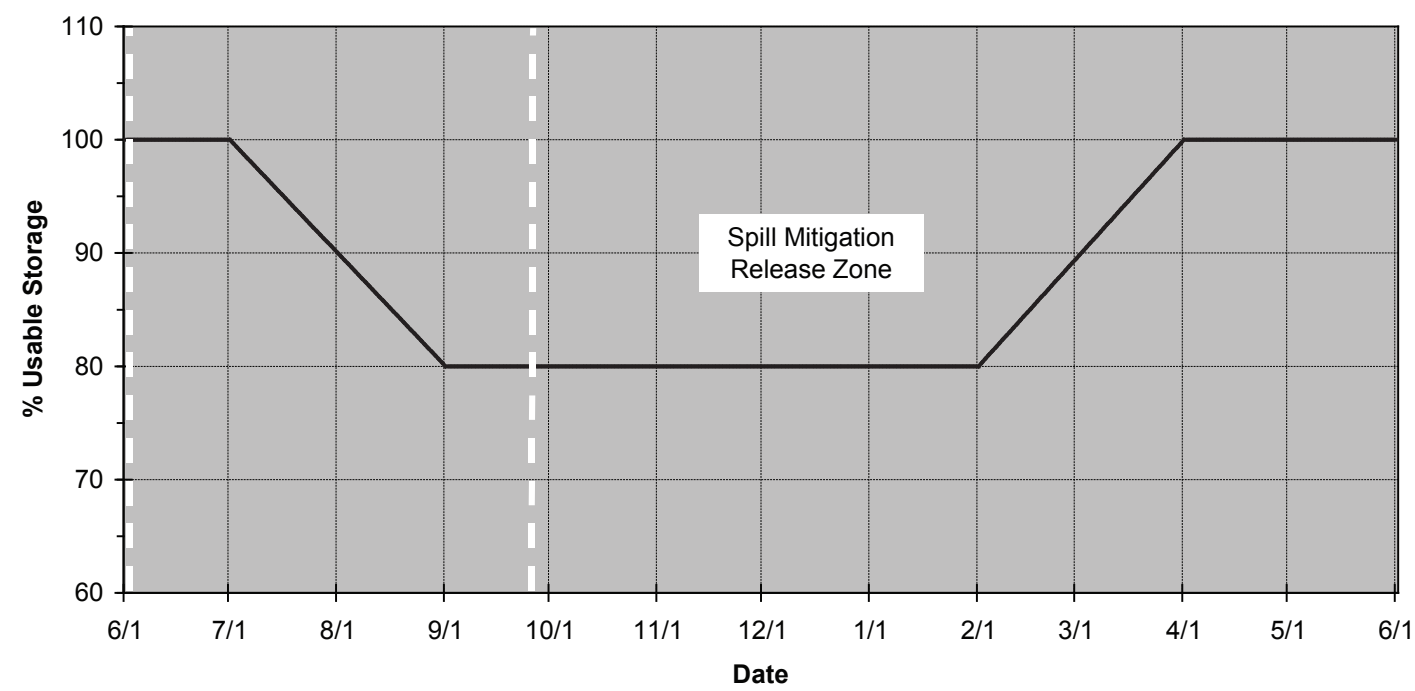

Figure 2

Delaware System Individual Reservoir Usable Storage

(Cannonsville, Pepacton, Neversink)

Spill Mitigation Rule Curves

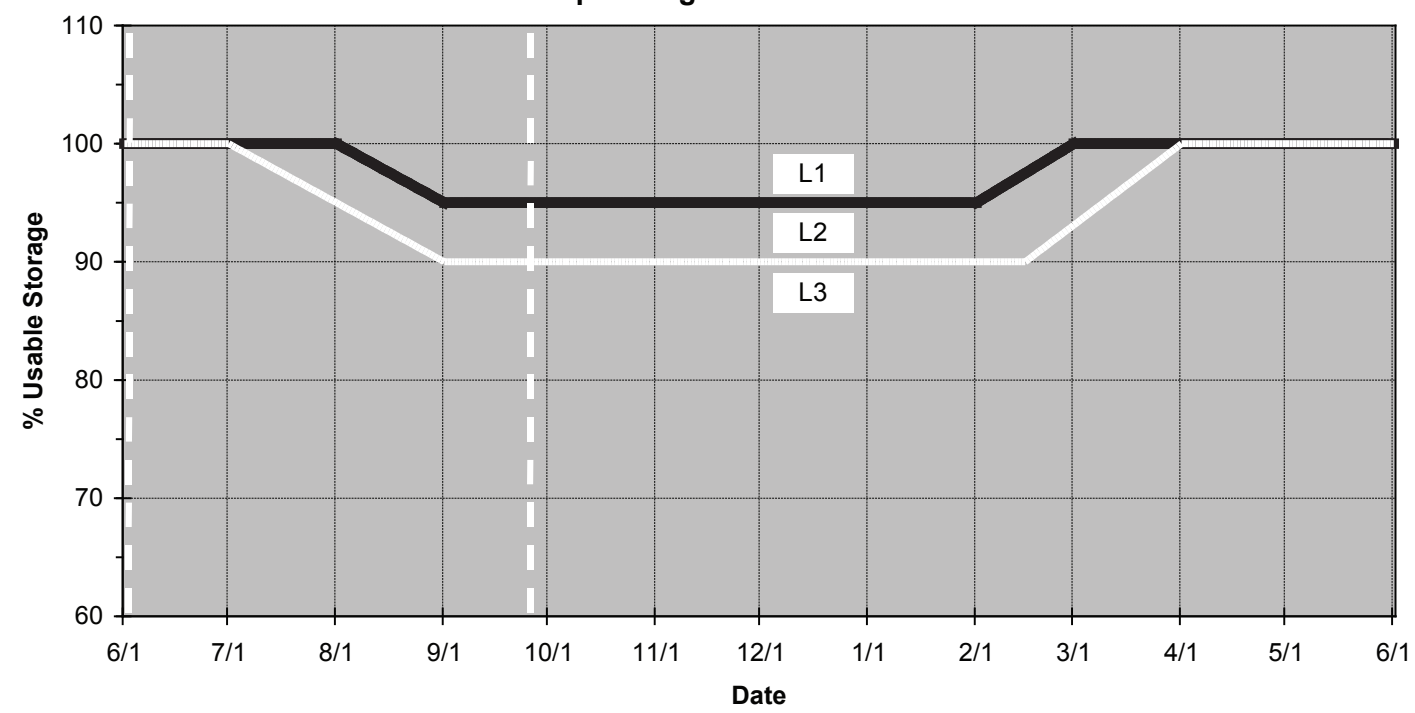


Table 1

\begin{tabular}{|c|c|c|c|c|c|}
\hline \multirow{2}{*}{$\begin{array}{c}\text { Cannonsville } \\
\text { Release Level }\end{array}$} & \multicolumn{5}{|c|}{ Release Rates (cfs) } \\
\hline & Oct 1 - Mar 31 & Apr 1 - Apr 30 & May 1 - May 31 & Jun 1 - Jun 30 & Jul 1 - Sep 30 \\
\hline L1 & 1000 & 1000 & --- & --- & 100 \\
\hline L2 & 250 & $\begin{array}{c}-- \\
--\end{array}$ & $\overline{---}$ & $\overline{---}$ & 350 \\
\hline L3 & 110 & $\begin{array}{c}-- \\
--\end{array}$ & 140 & 235 & 235 \\
\hline Pepacton & \multicolumn{5}{|c|}{ Release Rates (cfs) } \\
\hline Release Level & Oct 1 - Mar 31 & Apr 1 - Apr 30 & May 1 - May 31 & Jun 1 - Jun 30 & Jul 1 - Sep 30 \\
\hline L1 & 700 & 700 & --- & --- & 700 \\
\hline L2 & 185 & --- & --- & --- & 250 \\
\hline L3 & 85 & --- & 100 & 150 & 150 \\
\hline Neversink & \multicolumn{5}{|c|}{ Release Rates (cfs) } \\
\hline Release Level & Oct 1 - Mar 31 & Apr 1 - Apr 30 & May 1 - May 31 & Jun 1 - Jun 30 & Jul 1 - Sep 30 \\
\hline L1 & 190 & 190 & --- & --- & 190 \\
\hline L2 & 85 & $\begin{array}{c}-- \\
--\end{array}$ & --- & $-\overline{--}$ & 130 \\
\hline L3 & 65 & --- & 75 & 115 & 115 \\
\hline
\end{tabular}

4. Controlled reservoir releases will be made in accordance with the following:

i. For the period June 1 through June 30, Zones L1 and L2 shall not be applicable in accordance with Figure 2, and releases shall be made in accordance with Zone L3 as provided in Figure 2 and Table 1. Except as provided in paragraph viii, for the period June 1 through June 30, no spill mitigation releases shall be made.

ii. For the period July 1 through March 31, if combined reservoir usable storage is in the Spill Mitigation Release Zone in accordance with Figure 1, spill mitigation releases shall be made based upon individual reservoir usable storage in accordance with Zones L1, L2 and L3 as provided in Figure 2 and Table 1.

iii. For the period April 1 through April 30, if combined reservoir usable storage including snow pack as provided in paragraph iv is in excess of $100 \%$, spill mitigation releases shall be made based upon individual reservoir usable storage in accordance with Zone L1 as provided in Figure 2 and Table 1.

iv. During the period October 1 through April 30, a quantity of water equal to $50 \%$ of the water equivalent of snow pack storage in the watershed above each reservoir will be included in the storage calculation to determine the applicable combined reservoir usable storage zone in Figure 1 and the applicable respective reservoir usable storage zone in Figure 2 and Table 1.

v. For the period May 1 through May 31, Zones L1 and L2 shall not be applicable in accordance with Figure 2, and releases shall be made in accordance with Zone L3 as provided in Figure 2 and Table 1. Except as provided in paragraph viii, for the period May 1 through May 31, no spill mitigation releases shall be made.

vi. For the period ending May 31, whenever the combined reservoir usable storage in the NYC Delaware Basin Reservoirs is below the Spill Mitigation Release Zone as shown in Figure 1, releases from the NYC Delaware Basin Reservoirs will be made and accounted for in accordance with DRBC Docket D-77-20 (Revision 7). 
vii. For the period ending May 31, whenever the combined reservoir usable storage in the NYC Delaware Basin Reservoirs is in the Spill Mitigation Release Zone as shown in Figure 1 and spill mitigation releases are made in accordance with this spill mitigation program, to the extent necessary, habitat releases may be made to meet the habitat flow targets in accordance with DRBC Docket D-77-20 (Revision 7). There shall be no credits or debits to the Habitat Protection Bank as established in Revision 7 including without limitation to the Excess Release Quantity Bank portion of the Habitat Protection Bank provided from the Excess Release Quantity.

viii. At all times, if individual reservoir usable storage exceeds $100 \%$ at any reservoir, the NYCDEP and NYSDEC release managers may transfer up to $100 \%$ of spills at that reservoir to bottom releases to the extent possible as mutually agreed upon.

ix. The flood stage for the West Branch Delaware River at Hale Eddy is 11 feet. Accordingly, spill mitigation releases will not be made from Cannonsville Reservoir when the river stage for the West Branch Delaware River at Hale Eddy is above 9 feet, or is forecasted to be above 9 feet within 48 hours of a planned spill mitigation release from Cannonsville Reservoir. This guidance may be modified at any time if additional information demonstrates that a lower cautionary stage should be used to limit the spill mitigation releases.

x. The flood stage for the East Branch Delaware River at Fishs Eddy is $13 \mathrm{ft}$. Accordingly, spill mitigation releases will not be made from Pepacton Reservoir when the river stage for the East Branch Delaware River at Fishs Eddy is above $11 \mathrm{ft}$. or is forecast to be above 11 feet within 48 hours of a planned spill mitigation release from Pepacton Reservoir. This guidance may be modified at any time if additional information demonstrates that a lower cautionary stage should be used to limit the spill mitigation releases.

xi. The flood stage for the Neversink River at Bridgeville is 13 feet. Accordingly, spill mitigation releases will not be made from Neversink Reservoir when the river stage for the Neversink River at Bridgeville is above 12 feet, or is forecast to be above 12 feet within 48 hours of a planned spill mitigation release from Neversink Reservoir. This guidance may be modified at any time if additional information demonstrates that a lower cautionary stage should be used to limit the spill mitigation releases.

xii. Spill mitigation releases may be suspended from the respective reservoir if NYCDEP and NYSDEC in consultation with the National Weather Service determine that ice conditions threaten flood prone areas of the Neversink River below Neversink Reservoir, East Branch Delaware River below Pepacton Reservoir, or West Branch Delaware River below Cannonsville Reservoir.

xiii. Spill mitigation releases may also be suspended from the respective reservoir if the local, state and federal emergency management agencies recommend a need to temporarily suspend such releases.

xiv. Spill mitigation releases will be designed so that the combined discharge from each reservoir's controlled release works and spillway does not exceed the flow rate as detailed in Table 2 below. Respective controlled releases will be reduced to the conservation releases in Table 3 when the spillway discharge exceeds these flow rates.

xv. To more naturally effect downward transitions between spill mitigation release rates identified in Figures 1 and 2 and Table 1, spill mitigation release rates may be ramped generally over a period not to exceed three days at Cannonsville and Pepacton Reservoirs and not to exceed two days at Neversink Reservoir, but in increments no less than $10 \mathrm{cfs}$ at any reservoir. 
Table 2

\begin{tabular}{|l|c|}
\hline \multicolumn{1}{|c|}{ Reservoir } & Maximum Combined Spill/Release Flow Rate \\
\hline Neversink & $3400 \mathrm{cfs}$ \\
\hline Pepacton & $2400 \mathrm{cfs}$ \\
\hline Cannonsville & $4200 \mathrm{cfs}$ \\
\hline
\end{tabular}

Table 3. Conservation Releases

\begin{tabular}{|c|c|c|c|c|}
\hline \multirow[b]{2}{*}{ Reservoir } & \multicolumn{4}{|c|}{ Conservation Release (cfs) } \\
\hline & Normal & $\begin{array}{c}\text { Drought } \\
\text { Watch }\end{array}$ & $\begin{array}{l}\text { Drought } \\
\text { Warning }\end{array}$ & Drought \\
\hline Cannonsville (9/1-5/31) & 45 & 38 & 32 & 23 \\
\hline Cannonsville (6/1-8/31) & 60 & 51 & 43 & 23 \\
\hline Pepacton & 35 & 30 & 25 & 19 \\
\hline Neversink & 25 & 21 & 18 & 15 \\
\hline
\end{tabular}

5. This agreement will expire on September 26, 2007 and may be terminated at any time at the request of any Decree Party or may be modified with the unanimous consent of the Decree Parties. 


\section{Consent to Action by The City of New York}

Consent of the Parties to the U.S. Supreme Court Decree in New Jersey v. New York, 347 U.S. 995 (1954), approving the Temporary Spill Mitigation Program for Neversink, Pepacton and Cannonsville Reservoirs from June 1, 2007 through September 26, 2007, implemented by the City of New York.

/s/ Mark N. Mauriello

State of New Jersey Date

/s/ Kevin C. Donnelly

State of Delaware

Date

/s/ John H. Talley

State of Delaware
Date

$\frac{/ \mathrm{s} / \text { Mark Klotz }}{\text { State of New York }}$

/s/ Cathy Curran Myers

Commonwealth of Pennsylvania Date

/s/ Paul Rush

City of New York

Date 


\section{Appendix C}

\section{NO. $2007-7$}

A RESOLUTION to extend Revisions 7 and 9 of Docket D-77-20 CP, providing for, respectively, a program to manage releases from New York City's Neversink, Pepacton and Cannonsville reservoirs for the protection of fisheries, and a program to reduce the volume of spills from these reservoirs during floods.

WHEREAS, by Resolution No. 2004-3 in April of 2004, the Commission established a temporary release program known as "Revision 7"for the Neversink, Pepacton and Cannonsville reservoirs (hereinafter, "the City Delaware Reservoirs"), intended to protect the tailwaters fishery below these reservoirs for the period from May 1, 2004 through May 31, 2007; and

WHEREAS, by Resolution No. 2006-18 in September of 2006, the Commission established a program known as "Revision 9" to take effect from the date of its adoption through May 31, 2007 to reduce the volume of spills from the City Delaware Reservoirs during flood events; and

WHEREAS, Revisions 7 and 9 both were established with the understanding set forth in Resolution No. 2004-3 that the parties to the U.S. Supreme Court Decree of 1954 ("Decree Parties") would continue discussions to develop and implement by May 31, 2007 a long-term flexible program to manage releases from the City Delaware Reservoirs to better address multiple flow needs downstream; and

WHEREAS, between February 12 and March 1 of 2007, the Commission published in the federal and state registers and on its website notice that it would hold public hearings and accept written comments on a proposal by the Decree Parties for a Flexible Flow Management Plan (FFMP) that would provide a comprehensive framework for addressing multiple flow management objectives, including water supply, drought mitigation, flood mitigation, protection of the tailwaters fishery, a diverse array of habitat needs in the main stem, estuary and bay, recreational goals and salinity repulsion; and

WHEREAS, in response to its notice, the Commission received written and oral comments from approximately 140 agencies, organizations, elected officials and private citizens, including many substantive recommendations for enhancing the FFMP with respect to its multiple flow objectives; and

WHEREAS, in the course of the Decree Parties'continued negotiations over details of the FFMP, additional issues requiring negotiation arose, including a request by New Jersey for reexamination of the Commission's current drought operations plan, in order to better address water supply and flood mitigation needs throughout the basin; and

WHEREAS, the Decree Parties require additional time to review and fully consider the comments submitted by the public, to explore ways to accommodate New Jersey's request, and to craft a revised Flexible Flow Management Plan that attempts to better respond to competing needs; and

WHEREAS, the Commission's public notice announcing a comment period and hearings on the FFMP also invited the public to comment on alternative reservoir management strategies that might be adopted in the event that consensus on the FFMP were not reached. The notice stated that the alternative options to be considered were extending the current reservoir release program or reinstating a previous reservoir release program, and the notice further advised that either option would be considered in combination with a seasonal spill mitigation program or an annual spill mitigation program for the three City Delaware Reservoirs; and

WHEREAS, notwithstanding the shortcomings of the current fishery protection program known as Revision 7, the Decree Parties and the Commission find that this plan affords greater benefits than previous flow management regimes during the summer months, and wishes to secure these benefits for the approaching season; and 
WHEREAS, because the spill mitigation program set forth in Revision 9 was to be in place only from late September of 2006 through May of 2007 before being replaced by a more comprehensive program, Table 1 of Revision 9 does not include summer release rates to accompany the rule curves provided in Figures 1 and 2 of Revision 9; however, the rule curves establish that spill mitigation releases are to be made during the months of July through September when reservoir levels reach or exceed the useable storage levels established by the curves; and

WHEREAS, with the technical and administrative support of the Commission, the Decree Parties continue to evaluate their options for addressing the competing demands on the finite waters of the Delaware and intend to advance a revised FFMP proposal that is responsive to public comment, the evolving needs of the respective parties and the rights and obligations conferred by the Supreme Court Decree of 1954; now therefore,

BE IT RESOLVED by the Delaware River Basin Commission:

1. The releases program known as Revision 7 of Docket D-77-20 CP, which was established by Resolution No. 2004-3 to provide protection for fisheries below the City Delaware Reservoirs, is hereby extended through September 30, 2007.

2. The releases program known as Revision 9 of Docket D-77-20 CP, which was established by Resolution No. 2006-18 to reduce the volume of spills from the City Delaware Reservoirs during flood events, is hereby extended (as amended by Resolution No. 2007-1) through September 30, 2007.

3. The parties to the Supreme Court Decree of 1954 are hereby authorized and requested to agree prior to July 1, 2007 upon appropriate reservoir spill mitigation release rates for the City Delaware Reservoirs to be implemented for the period from July 1 through September 14 consistent with the spill mitigation rule curves that appear in Figures 1 and 2 of Revision 9, provided that in the absence of public notice and a hearing before the Commission, such release rates shall not exceed the maximum rates of 1000 cubic feet per second (cfs) for Cannonsville, $700 \mathrm{cfs}$ for Pepacton, and $190 \mathrm{cfs}$ for Neversink set forth in Table 1 of Revision 9. The release rates agreed upon by the Decree Parties will be posted on the Commission's website as soon as they become available.

4. Public notice, the opportunity for further written comment and a public hearing will be provided prior to Commission action on a revised Flexible Flow Management Plan, when such a plan is submitted by the Decree Parties for the Commission's consideration.

/s/ William A. Gast

William A. Gast, Acting Chairman pro tem

/s/ Pamela M. Bush

Pamela M. Bush, Esquire, Commission Secretary

ADOPTED: May 10, 2007 



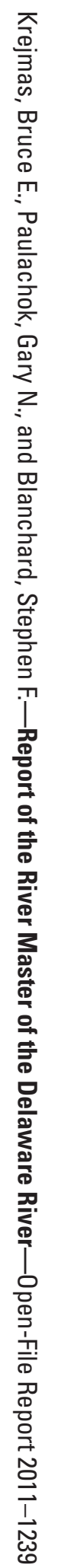

8 Printed on recycled paper 